Cornell Law Library

Scholarship@Cornell Law: A Digital Repository

Cornell Law Faculty Publications

Faculty Scholarship

4-1995

\title{
Are Stock Markets Costly Casinos? Disagreement, Market Failure, and Securities Regulation
}

Lynn A. Stout

Cornell Law School,1s483@cornell.edu

Follow this and additional works at: http://scholarship.law.cornell.edu/facpub

Part of the Corporation and Enterprise Law Commons, and the Securities Law Commons

\section{Recommended Citation}

Stout, Lynn A., "Are Stock Markets Costly Casinos? Disagreement, Market Failure, and Securities Regulation" (1995). Cornell Law Faculty Publications. Paper 751.

http://scholarship.law.cornell.edu/facpub/751

This Article is brought to you for free and open access by the Faculty Scholarship at Scholarship@Cornell Law: A Digital Repository. It has been accepted for inclusion in Cornell Law Faculty Publications by an authorized administrator of Scholarship@Cornell Law: A Digital Repository. For more information, please contact jmp8@cornell.edu. 


\title{
VIRGINIA LAW REVIEW
}

\begin{tabular}{lll}
\hline VOlume 81 & APRIL 1995 & NUMBER 3
\end{tabular}

ARTICLES

\author{
ARE STOCK MARKETS COSTLY CASINOS? \\ DISAGREEMENT, MARKET FAILURE, AND \\ SECURITIES REGULATION
}

\author{
Lynn A. Stout*
}

INTRODUCTION ..................................... 613

I. A Heterogeneous Expectations Model of Stock Trading........................................ 620

A. The Puzzle of Speculative Stock Trading ........... 622

B. A Simple Model of Heterogeneous Expectations and HE Trading in a World of Imperfect Information ... 625

C. Potential Deterrents to HE Trading: The Roles of Self-Selection and Successive Generations in Fostering Speculative Markets....................

1. Optimistic Self-Selection and the Lake Wobegon Market ......................................

* Professor of Law, Georgetown University Law Center, Guest Scholar, The Brookings Institution. A.B. 1979, M.P.A., 1982, Princetou University; J.D., 1982, Yale University. Earlier versions of this Article were presented at the Annual Meeting at the American Law and Economics Association, and at workshops at the Duke University School of Law, Georgetown University Law Center, George Mason University Scliool of Law, and the New York University School of Law. The author would like to thank the participants in those sessions for their helpful comments and insights. The author also would like to thank Jean-Pierre Beuoit, Mark Geistfeld, Marcel Kahan, Michael Klausner, Avery Katz, Don Langevoort, Mark Ranseyer, Steve Salop, Warren Schwartz, Joel Seligman, Jack Slain, and Pete Wales for their readings and suggestions, and Alan Cabral, Neal Kochnian, Tonya Lindsey, Alex Sliheet, and Frank Supik for their nuvaluable assistance researching and preparing this manuscript. 
2. A Longitudinal Model of HE Trading: Darwin Meets Barnum ......................... 637

D. The Role of Financial Intermediaries in

Encouraging $H E$ Trading...................... 641

I. The Role of Brokers .......................... 641

2. The Role of Institutional Investment Funds ...... 643

E. HE Theory and the Relationship Between Stock

Prices and Fundamental Values in an Efficient

Market................................... 646

1. The Rise (and Fall?) of Conventional Efficient Markets Theory .......................... 646

2. Modifying Conventional Efficient Markets

Theory To Account for Heterogeneous

Expectations.

II. Are U.S. Stock Markets Heterogeneous

EXPECTATIONS MARKETS?

A. Nonmistaken Reasons for Trading and the ValueAdding Model of Stock Markets .

B. The Value-Adding Model Versus the HE Model:

Some Evidence on Why Investors Trade...

1. The Predominance of Active Institutional

Management .............................. 661

2. Trading Volume and Patterns ............... 665

III. The Policy Implications of the Heterogeneous Expectations Model for Federal Securities

REgulation ................................... 667

A. The Social Costs of HE Trading ................ 669

I. Welfare Losses Resulting From HE Traders'

Mistaken Investment in Active Portfolio

Management ........................... 670

2. Welfare Losses From HE Trading's Distortive Effects on Stock Prices ..................... 677

B. The Social Benefits of HE Trading ............. 682

1. HE Trading and Market Liquidity ............ 683

2. HE Trading and The Fundamental Value Efficiency of the Market .................. 688

C. Reducing Welfare Losses from HE Trading: Some Policy Implications. 


\section{Reducing Welfare Losses From HE Trading} Through Rules That Reduce the Dispersion of Investor Expectations .........................

2. Reducing Welfare Losses From HE Trading Through Rules That Decrease the Costs of Speculative Trading

3. Reducing Welfare Losses From HE Trading by Taxing or Prohibiting Trading .................

D. Some Thoughts on the HE Theory's Applicability to Other Speculative Markets, Especially Derivatives Markets ...................................... 703

IV. Conclusion ................................ 710

\section{INTRODUCTION}

THE U.S. stock market is one of the largest markets in the world. In 1992, over three trillion dollars in shares changed hands on the exchanges and im the over-the-counter ("OTC") market, ${ }^{1}$ almost twice as much as consumer spending on durable and nondurable goods combined. ${ }^{2}$ Trading on such a gargantuan scale costs investors $\$ 100$ billion or more annually. ${ }^{3}$ Despite these costs, trading volume on the exchanges and in the OTC market has quadrupled over the past decade. ${ }^{4}$ Moreover, imvestors no longer are content to trade just stocks; they now trade stock "derivatives," complex financial instruments whose values depend on the prices of pubhicly traded equities. 5

1 National Ass'n of Securities Dealers, 1993 Nasdaq Fact Book \& Company Directory 7 (1993) (stating that in $1992 \$ 1.75$ trillion traded on New York Stock Exchange and $\$ 1.31$ trillion traded on regional exchanges and in OTC market).

2 See Bureau of the Census, U.S. Dep't of Commerce, Statistical Abstract of the United States 1993, at 442 tbl. 690 (113th ed. 1993) [hereinafter 1993 Statistical Abstract] (charting the $\$ 480.4$ billion and $\$ 1290.7$ billion spent on durables and nondurables, respectively, in 1992).

3 See infra notes 191-207 and accompanying text (noting that mutual funds' expense ratios suggest investors spend at least $\$ 100$ billion annually researching, nuanaging, and trading stock portfolios).

4 See National Ass'n of Securities Dealers, supra note 1, at 6 (noting that NASDAQ annual dollar volume rose from $\$ 84$ billion in 1982 to $\$ 891$ billion in 1992); 1993 Statistical Abstract, supra note 2, at 522 tbl. 829 (noting that dollar volume on all exchanges rose from $\$ 476$ billion in 1980 to $\$ 1612$ billion in 1990).

5 See infra notes 313-25 and accompanying text (describing aspects of derivatives trading). 
Why do traders trade? A common assumption is that equities trading serves both buyers' and sellers' self-interest, as well as the interest of the larger society. ${ }^{6}$ In the tradition of classical economics, exchange between rational actors is equated with mutual benefit and a corresponding increase in social welfare. ${ }^{7}$ Thus, scholars and regulators beheve that more stock tradimg is better than less, that mcreasing opportunities to trade stocks is desirable, and that lowering trading costs, includimg regulatory costs, is an important policy goal. ${ }^{8}$ Congress and the Securities and Exchange Commis-

6 The securities literature often assumes that stock trades are mutually beneficial. See, e.g., Thomas Lee Hazen, Rational Investments, Speculation, or Gambling?-Derivative Securities and Financial Futures and Their Effect on the Underlying Capital Markets, 86 Nw. U. L. Rev. 987 (1992) (suggesting that securities regulation is premised on the view that government should not interfere with investınent decisions); Donald W. Kiefer, The Security Transactions Tax: An Overview of the Issues, 48 Tax Notes 885, 896 (1990) (arguing against tax that discourages trading as cutting against economic assumption that activity is valuable if participants are willing to pay for it); Donald C. Langevoort, Information Teclnology and the Structure of Securities Regulation, 98 Harv. L. Rev. 747, 803 (1985) (noting that information technology that lowers trading costs benefits imvestors); Robert W. Vishny, Three Comments on Economic Imphcations of Alternative Portfolio Pohcies of Institutional Investors, in Institutional Investing: Challenges and Responsibilities of the 21st Century 159, 165-66 (Arnold W. Sametz ed., 1991) (defending stock trading as activity of "consenting adults"); see also Division of Mkt. Regulation, SEC, Market 2000: An Examination of Current Equity Market Developments 1 (1994) [hereinafter Market 2000 Report] (praising U.S. stock markets for "[r]ecord amounts of trading activity").

In addition to its presumed benefits to trading parties, stock trading also is believed to provide significant social benefits by contributing to the "liquidity" and "efficiency" of the market. See infra notes 234-239, 257-258 and accompanying text.

Only a handful of scholars liave suggested that stock trading is not socially valuable. See infra note 10.

7 See Richard A. Posner, Economic Analysis of Law 10-11 (4th ed. 1992) (stating that a basic principle of economics is that voluntary exchange is efficient because it helps move resources to those who value them most highly, as measured by willinguess to pay). The classic statenent of this proposition is, of course, Adam Smith's discussion of the "imvisible hand." See Adam Smith, An Inquiry imto the Nature and Causes of the Wealth of Nations 456 (R.H. Campbell \& A.S. Skinner eds., 1976) (1776).

8 For example, the assumption that stock trading is beneficial has played a large role in recent debates over proposals to reinstate a federal stock transfer tax. See, e.g., G. William Schwert \& Paul J. Seguin, Securities Transaction Taxes: An Overview of Costs, Benefits and Unresolved Questions 1 (1993) (stating that decreasing trading reduces market efficiency and hquidity and drives trading overseas); Kiefer, supra note 6, at 896 (arguing against tax aimed at discouraging stock trading); Myron S. Scholes, Tax Treatinent of Short-Term Trading, in Institutional Investing: Challenges and Responsibilities of the 21st Century, supra note 6 , at 150,155-56 (arguing that a stock transaction tax is undesirable because it will "reduce demand for trading" and that tax pohicy should not discourage stock trading but should "be directed at imcreasing the supply of transaction services"). 
sion ("SEC") praise stock markets as paragons of efficiency to be protected and promoted. ${ }^{9}$

This Article explores an alternative view of stock trading. ${ }^{10}$ Usmg rational choice analysis and information theory, it presents a

The assumption that trading is beneficial also underlies federal authorities' reluctance to regulate the emerging market for equities derivatives. See, e.g., Division of Mkt. Regulation, SEC, The Role of Index-Related Trading in the Market Decline on September 11 and 12,1986, at 17 (1987) (arguing that trading in stock index options and futures offers "significant benefits to today's capital markets" by adding liquidity and efficiency to equity markets and allowing investors to control the risk of their portfolios); Hazen, supra note 6, at 988,1021 (noting that current regulatory policy, whicl is based on a model of rational and socially beneficial trading, has sanctioned and encouraged proliferation of derivative investınents); see also Henry T.C. Hu, Misunderstood Derivatives: The Causes of Informational Failure and the Promise of Regulatory Incrementalism, 102 Yale L.J. 1457, 1513 (1993) (arguing that a prohibition of derivatives trading would be "destructive of social wealth"); Robert Lenzner \& William Heuslem, The Age of Digital Capitalism, Forbes, Mar. 29, 1993, at 62, 64-65 (arguing against regulation of derivatives trading on the grounds that trading serves "powerful demand" and provides benefits to trading parties); Lawrence H. Summers \& Victoria P. Summers, When Financial Markets Work Too Well: A Cautions Case for a Securities Transactions Tax, 3 J. Fin. Services Res. 261, 264 (1989) ("Fmancial innovators and their academic champions argue that the facilitation of trading necessarily contributes to economic efficiency.").

9 See, e.g., H.R. Rep. No. 355, 98th Cong., 1st Sess. 22 (1983) reprinted in 1984 U.S.C.C.A.N. 2274, 2294 (noting and adopting SEC's view that U.S. securities markets are "the best ... the world lias ever known" because they are "liquid, efficient, and fair"); U.S. Equity Market Structure Study, 57 Fed. Reg. 32,587 (1992) (praising the U.S. for having the "largest, most diverse, and most innovative securities markets in the world," and noting that their continued strength and vitality are "critical to the economic welfare of all Americans"); Market 2000 Report, supra note 6, at 1 (describing stock markets as an "important national asset" and praising U.S. markets as "the most efficient and hquid in the world" with "[r]ecord amounts of trading activity"); see also Josepl E. Stiglitz, Using Tax Policy To Curb Speculative Short-Term Trading, 3 J. Fm. Services Res. 101, 113 (1989)

("No mstitution in our capitalist society is as venerable as the stock market.").

10 Stock markets are not without their critics. John Maynard Keynes, who likened stock markets to casimos, once proposed that society might be significantly better off with less stock trading. Jolin M. Keynes, The General Theory of Employment, Interest, and Money 159-60 (1st Harbinger ed. 1964). A handful of contemporary scholars have followed Keynes' lead by questioning the social benefits of high-volume stock trading. See Louis Lowenstein, What's Wrong with Wall Street: Short-term Gain and the Absentee Shareholder 80-86 (1988) (suggesting social costs of high-volume markets exceed their benefits); Stightz, supra note 9, at 103 (questioning benefits of stock trading to traders and suggesting that from a social perspective, it may be desirable to discourage excessive trading); Summers \& Summers, supra note 8, at 262, 271-72 (suggesting that stock market trading is efficient ouly "[i]n the narrow sense of permitting trade to take place between consenting adults" and that excessive costs may be associated with the zero-snm gaine of speculation); James Tobm, On the Efficiency of the Financial System, Lloyds Bank Rev., July 1984, at 1,2, 15 (questioning economic benefits of financial markets and their "casino aspect"). Most academic economists, however, have given such suggestions a cool 
model of stock trading premised on the observation that, in a world of costly and imperfect information, rational investors are likely to form heterogeneous expectations - that is, to inake different forecasts of stocks' hikely future performance. ${ }^{11}$ The heterogeneous expectations ("HE") model predicts that investors' asymmetrical expectations will inspire them to seek short-term profits by speculating $^{12}$ on stocks they perceive as mispriced. Thus, John buys

reception. Many are disturbed by the claim that stock markets are "too speculative," believing it implies that stock traders are irrational or that stock markets somehow defy the laws of econoumics. See, e.g., Donald W. Kiefer, Cong. Res. Serv., Are Pension Funds Short-Term Investors? 14-15 (1992) (suggesting that if investors do systematically lose wealth by excessive trading, "inefficient behavior persists on a grand scale in [the stock] market," and as "a serious reconsideration of some of the most basic principles of economic theory may be necessary"); Kiefer, supra note 6, at 896 (rejecting suggestion that stock tradiug leads to social waste of resources as "conjectural" and as "more a statement of personal value judgment than the result of rigorous application of standard primciples of economic analysis"); Steplen A. Ross, Commentary: Using Tax Policy To Curb Speculative Sliort-Term Trading, 3 J. Fin. Services Res. 117, 117-118 (1989) (decrying argument that stock trading should be discouraged as paternalistic and itself "speculative"); Robert W. Vishny, supra note 6, at 165-66 (describing argument that stock trading wastes resources as "dangerous"); see also Stiglitz, supra note 9 at 104 (noting that traditional economic texts empliasize importance of mutual gains from excliange and do not question source of stock traders' preferences); Tobin, supra, at 2 (noting that skepticism about social value of financial markets runs "against current tides," including a "general entlusiasm for deregulation and unfettered competition" and economists" "intellectual admiration for the efficiency of financial markets"); cf. J. Bradford De Long, Andrei Shleifer, Lawrence H. Summers \& Robert J. Waldmann, Noise Trader Risk in Financial Markets 98 J. Pol. Econ. 703, 731-32 (1990) [hereinafter De Long et al., Noise Trader Risk] (noting that arguments considering short-term speculation to be socially destructive have "found little academic sympathy").

11 In another work, I use the phrase "lieterogeneous beliefs" in describing why different investors unight attacl differing subjective values to the same securities. Lynn A. Stout, Are Takeover Premiums Really Premiums? Market Price, Fair Value, and Corporate Law, 99 Yale L.J. 1235, 1239 (1990). The more specific phrase "lieterogeneous expectations" is used here because the phrase "lieterogeneous beliefs" could include differences in perfectly informed investors' preferences for risk, liquidity, and so forth. See infra notes 136-144 and accompanying text (discussing nonmistaken differences in preferences as reasons for trading).

12 Financial theorists have yet to agree on a definition of "speculation." Ohiver D. Hart \& David M. Kreps, Price Destabilizing Speculation, 94 J. Pol. Econ. 927, 928 (1986). This Article defines speculation as the purchase of an item not for consumption, but in the lope of profiting from resale by predicting future price clianges. Cf. Jack Hirshleifer, Time, Uncertainty, and Infornation 186 (1989) (defining speculation as "purcliase with the intention of re-sale, ... where the uncertainty of the future spot price is a source of both risk and gaim"); James R. Repetti, The Use of Tax Law To Stabilize the Stock Market: The Efficacy of Holding Period Requirements, 8 Va. Tax Rev. 591, 596 (1989) (defining speculation as "the purchase of an item with a view to selling it at a higher price within a short period of time"). 
General Motors expecting that GM's share price will soon rise, whereas Mary sells expecting GM to decline.

The HE model of trading offers important insights into the workings of U.S. equities markets. For example, empirical studies indicating that stock markets do not accurately price securities have sparked much debate among legal and financial scholars over whether modern equities markets conform to the Efficient Capital Markets Hypothesis ("ECMH"). ${ }^{13}$ The HE model consequently offers an answer to the controversy by explaining why, when imvestors disagree, "efficient" markets that rapidly respond to new information can nevertheless produce prices that depart substantially from best estimates of stocks' fundamental values. ${ }^{14}$

Perhaps more important, the HE trading model carries profound normative imphications for the social value of stock markets. Stock trades motivated by heterogeneous expectations appear mutually beneficial ex ante but inevitably disappoint at least one party ex post. After all, when John buys GM hoping to profit from a price rise and Mary sells expecting to avoid a decline, both cannot be right. Moreover, trading requires both parties to imcur costs,

13 The phrase "efficient stock market" generally alludes to a highly specialized notion of efficiency associated with the ECMH. See Richard A. Brealey \& Stewart C. Myers, Principles of Corporate Finance 290-310 (4th ed. 1991); Edwin J. Elton \& Martin J. Gruber, Modern Portfolio Theory and Investment Analysis 399-433 (4th ed. 1991); Eugene F. Fama, Efficient Capital Markets: A Review of Theory and Einpirical Work, 25 J. Fin. 383 (1970); Ronald J. Gilson \& Reinier H. Kraakman, The Mechanisins of Market Efficiency, 70 Va. L. Rev. 549 (1984); Jeffrey N. Gordon \& Lewis A. Kornhauser, Efficient Markets, Costly Information, and Securities Research, 60 N.Y.U. L. Rev. 761 (1985). In its classic form, the ECMH simply predicts that prices in a well-developed stock market respond so quickly to new information that it is impossible for investors to earn short-run profits by buying on good news or selling on bad news. See Gordon \& Kornhauser, supra, at $771 \mathrm{n} .19$ (describing market as efficient with respect to an information set if it is impossible for investors to profit by trading on that information set); see also Gilson \& Kraakman, supra, at 560 (noting that requirement that prices always refiect new information means that market mechanisms function rapidly enough to foreclose trading opportunities froin new information). Many scholars also believe, however, that informationally efficient stock markets produce prices that reflect the best possible estimates of fundamental economic values as ineasured in terms of likely risk and return. See infra notes 95-100 and accompanying text (describing concepts of Capital Asset Pricing Model and fundaniental value efficiency); infra notes 101-12 and accoinpanying text (describing controversy surrounding fundamental value efficiency).

14 HE theory suggests that informationally efficient markets may react quickly to new information, yet still produce prices that depart from fundamental values. See infra notes 120-35 (discussing HE inodel's iniphcations for market efficiency). 
including but not limited to broker commissions. The HE model suggests that stock trading may be a form of market failure due to imperfect information. ${ }^{15}$ Unless $\mathrm{HE}$ trading provides social benefits outweighing its costs, such trading reduces society's wealth along with the wealth of the average HE trader.

That possibihty seriously undermines much of the laissez-faire structure of modern securities law. A fundamental premise of the current regulatory scheine is that stock trading is socially beneficial. In the interest of reducing trading costs and increasing opportunities for trading, regulators in recent years have repealed stock transfer taxes, ${ }^{16}$ eliminated fixed brokerage commissions, ${ }^{17}$ encouraged the development of new trading systeins and markets, ${ }^{18}$ extended the trading hours of existing markets, ${ }^{19}$ and sanctioned trading in securities derivatives, mcluding stock index options and futures. ${ }^{20}$ If the HE model accurately describes modern stock inarkets, however, policies that encourage stock trading may, on the inargin, reduce net social welfare. Far from being engines of efficiency, high-volunie stock inarkets may generate inefficiency and deadweight social loss.

15 The phrase "Inarket failure" describes instances in which rational, self-interested individuals pursue courses that ultimately reduce their net welfare. In the case of stock trading, imperfect information inay be the source of market failure. Infra notes 35-45 and accoinpanying text.

16 See generally 1 Louis Loss \& Joel Seligman, Securities Regulation 329 n.18 (3d ed. 1989) (discussing the repeal of federal transfer tax); Kiefer, supra note 10, at 23 (noting repeal of federal and New York state transfer taxes).

17 See generaily 6 Loss \& Seligman, supra note 16, at 2851-80 (laying out the policy debate over elimination of fixed commissions); infra notes $59-60$ and accompanying text (describing the deregulation of commissions).

18 See Langevoort, supra note 6, at 754 (describing Congress' direction that SEC help develop "national market system" to ensure inore efficient and competitive narketplace); see also Brandon Becker, Global Securities Markets, 6 Int'l Tax \& Bus. Law. 242, 249-53 (1988) (describing proposals to develop new trading systeins).

19 See Becker, supra note 18, at 250, 253-54 (noting that extending trading hours is consistent with SEC's goal of facilitating international trading); Steplen Labaton, New Stock Trading Approved, N.Y. Times, Oct. 11, 1991, at D1 (describing SEC's approval of early-1norning trading in OTC stocks); see also Laura S. Greenstein, The Future of Global Securities Transactions: Blocking the Success of Market Links, 11 Md. J. Int'l L. \& Trade 283, 286 (1987) (noting that securities professionals are proposing 24-liour market); cf. Aulana L. Peters, Overview of International Securities Regulation, 6 Int'l Tax \& Bus. Law. 229, 230 (1988) (providing argument of SEC commissioner that liberalizing access to securities markets enhances efficiency of those markets).

20 See infra notes 320-22 and accompanying text (noting that the benefits of trading are used to defend derivatives). 
Part I develops the basic HE model of trading by examining how, when information costs are positive, rational investors form heterogeneous expectations that induce thein to hope ex ante to profit from speculative transactions that actually reduce their net wealth ex post. Part I examines the effect of optimistic self-selection in determining who trades stocks, the importance of generational factors in ensuring that speculative markets persist despite evolutionary pressures that "weed out" unsuccessful traders, and the roles of brokers and institutional investment funds in increasing the imcidence of HE trading. Part I also explores the HE model's controversial imphications for the accuracy of stock prices in "efficient" unarkets.

Part $I$ addresses the einpirical validity of the HE model by considering alternative reasons why investors might trade stocks, including hquidity, tax benefit, and portfoho balancing concerns. The available evidence suggests that although such motivations account for a portion of stock trading, investor disagreement inspires the hon's share of equities transactions.

Part III explores the pohcy imphications of the HE model by examining the social costs and benefits of stock speculation through the lens of HE theory. Investors appear to spend at least $\$ 100$ billion annually-approximately twenty percent of the returns from stock ownership-researching, managing, and trading corporate equities. $^{21}$ If most stock trades are $\mathrm{HE}$ trades, much of that $\$ 100$ billion represents a net loss to investors. Stock speculation also may impose a second, more subtle, form of social cost if speculators' optimistic hopes of trading profits create "false substitution" and "false valuation" effects that distort investor demand for corporate equity. Nevertheless, from a social perspective, costs associated with HE trading would be worthwhile if HE trading provided even larger social benefits. Two benefits often associated with speculative stock trading are more hquid markets that encourage capital formation and more efficient (i.e., accurate) stock prices. Part III examines the liquidity and efficiency claims and concludes that the marginal social benefits that flow from speculative trading likely are significantly outweighed by the marginal costs. Part III addresses the regulatory implications of this conclu-

21 Infra notes 191-207 and accompanying text. 
sion by examining three basic policy approaclies to reducing deadweiglit losses from HE trading: (1) reducing investor disagreement, (2) decreasing trading costs, and (3) taxing or prohibiting tradimg. Part III also discusses the value of eacli approach im the context of the modern regulatory sclieme of mandatory disclosure accompamed by rules against fraud.

The analysis presented below focuses primarily on trading in public markets for corporate equities. That clroice of empliasis reflects both the greater availability of data on equities markets and the relative simplicity of modeling equities trading. But lessons learned from stock markets may apply to other markets as well. The HE model of trading is im essence a model of rationalbut ultimately self-defeating and socially wasteful-speculation. Part III concludes by briefly considering soine of the broader implications of the HE model for otlier markets and especially for the emerging market for financial derivatives.

\section{A Heterogeneous Expectations Model of Stock Trading}

Corporations issue stock in the primary market for corporate equity by selling shares to imvestors im exchange for additional capital. 22 Most companies issue equity only rarely; after "going public," a firm might never peddle stock to outside investors agam. ${ }^{23}$ Once issued, however, a firm's shares will continue to be traded froin investor to investor on secondary markets sucl as the exchanges and the National Association of Securities Dealers Automatic Quotation ("NASDAQ") over-the-counter system. ${ }^{24}$

22 See generally Brealey \& Myers, supra note 13, at 339-43 (discussing venture capital and the public offering); Robert A. Haugen, Modern Investment Theory 25-26 (3d ed. 1993) (describing the difference between primary and secondary markets).

23 See Lynn A. Stout, The Unimportance of Being Efficient: An Economic Analysis of Stock Market Pricing and Securities Regulation, 87 Mich. L. Rev. 613, 646-47 \& 647 n. 185 (1988) (noting that public issuances are rare).

24 Commentators who speak of "the stock market" almost invariably are referring to the secondary markets. Their choice of emphasis reflects the reality that, although secondary market trades provide no additional capital to corporations, they account for the overwlielming majority of all stock transactions. For cxample, in the flve-year period from 1988 througl 1992, trading on the secondary markets outweighed corporate issues by a ratio of 50 to one. See Securities Indus. Ass'n, Securities Industry Yearbook 947 (Rosalie Pepe ed., 1993) (noting that from 1988 through 1992, U.S. firms underwrote annual average of $\$ 40$ billion im common stock issues); id. at 948,949 (noting that froin 1978 
Secondary market investors buy and sell eagerly and often. In 1992 , nearly half of the shares histed on the NYSE changed hands. ${ }^{25}$ In the OTC market, the dollar volume of trading in NASDAQhisted stocks amounted to $160 \%$ of the total value of shares listed, implying an average investor holding period of less than eight months. ${ }^{26}$

What drives such secondary market turnover? Both scholars and laymen generally assume that disagreement underhies most stock trading. ${ }^{27}$ John buys General Motors predicting its stock will soon rise, whereas Mary sells, expecting GM to fall. Investors' differing expectations lead them to perceive opportunities to profit by buymg stocks they behieve are underpriced and selling (or selling short) ${ }^{28}$ stocks they behieve are overpriced. Some imdividual investors do their own buying and selling. Many more speculate indirectly by putting money into "actively managed" pension or mutual funds that trade on their behalf. In either case, trading is moti-

through 1992, investors traded an average of $\$ 2.061$ trillion in stock annually on the NYSE and NASDAQ markets alone).

25 In 1992, investors traded 51.8 billion (45\%) of the NYSE's 115.8 billion listed shares. 1993 Statistical Abstract, supra note 2, at 524 tbls. 833, 834. In dollar volume terms, NYSE trading in 1992 amounted to $44 \%$ of the value of all shares listed, implying an average holding period of less than 28 months. Id; see New York Stock Exchange, Fact Book for the Year 1992, at 11, 32 (1993) (listing $\$ 1.745$ trillion trading volume and $\$ 4.035$ trillion market value of listed shares).

${ }^{26}$ The total dollar volume of trading on NASDAQ was $\$ 891$ billion in 1992 , whereas the total market value of NASDAQ listed equities was $\$ 556$ billion. Nasdaq Fact Book 1993, supra note 1, at 7,11 . The Nasdaq Fact Book does not provide the information needed to calculate share turnover.

27 See Donald C. Langevoort, Theories, Assumptions, and Securities Regulation: Market Efficiency Revisited, 140 U. Pa. L. Rev. 851, 895 (1992) (noting the popular assumption that most investors trade because they believe the market misvalues stocks); see also William J. Carney, Shareholder Coordination Costs, Shark Repellents, and Takeout Mergers: The Case Against Fiduciary Duties, 1983 Am. B. Found. Res. J. 341, 385 (describing stock markets as "built . . . on differing expectations"); Gordon \& Kornhauser, supra note 13, at $781 \mathrm{n} .49$ (observing that differences in beliefs are occasions for trade); Stiglitz, supra note 9, at 102, 104 (stating that stock exchanges are largely motivated by "differences in judgments" concerning stocks' yields).

28 Short selling is akin to selling "borrowed" stock. A short sale is a bet that the market price of the shorted shares will fall before the short seller must purchase the shares on the open market and return them to the "lender." As a practical matter, legal restrictions and market risks ensure that short selling is extrenely rare. Stout, supra note 11, at 1248 n.68. See generally Jonathan R. Macey, Mark Mitchell \& Jeffry Netter, Restrictious on Short Sales: An Analysis of the Uptick Rule and Its Role in View of the October 1987 Stock Market Crash, 74 Cornell L. Rev. 799 (1989) (analyzing restrictions on short selling). 
vated by the desire to achieve returns greater than those available from simply buying and holding a market portfolio. Thus the popular image of stock markets populated by individual and institutional traders trying to "beat the market" by buying and selling based on their predictions for companies, industries, and the inarket as a whole.

\section{A. The Puzzle of Speculative Stock Trading}

On closer inspection, however, the idea of investors trying to make inoney by buying and selling mispriced stocks seems puzzling, for stock trading is a zero-sum game. ${ }^{29}$ Owning stocks is not zero-sum: if stocks tend to appreciate over time, investors generally can increase their wealth by buying, and holding, equities. But trading simply transfers the benefits (or costs) of equity ownership from one investor to another. If John buys GM from Mary at $\$ 100$ and GM rises to $\$ 105$, John is five dollars wealthier, but Mary lias lost the opportumity to enjoy that five dollar gam lierself. Similarly, if GM falls to ninety-five dollars, Mary avoids a five dollar loss, but only by passing that loss on to John. That stock trading is zerosum does not imply that no investor can increase her returns from stock ownership by trading. For every talented or lucky trader who earns above-market returns, however, some other trader or traders inust be earning below-inarket returns.

The idea of a market of traders trying to beat the market seems even odder when one considers that investors who trade incur broker fees, research costs, and other expenses. Zero-sum games that involve playing costs becoine negative-sum games im whicl the average player loses money. Trading costs ensure that investors who trade earn lower returns on average than investors who do not, just as the "house cut" ensures that gamblers on average exit

29 See William J. Baumol, Speculation, Profitability, and Stability, 39 Rev. of Econ. \& Stat. 263, 264 (1957) ("Whatever one group of traders gains another mnst lose."); John C. Coffee, Jr., Market Failure and the Ecouomic Case for a Mandatory Disclosure System, 70 Va. L. Rev. 717, 733 (1984) (explaining that secondary market trading does not create wealth because one party's gain comes from another's loss); Summers \& Summers, supra note 8 , at 272 (recognizing that trading is a zero-sum game); Jack L. Treynor, Types and Motivations of Market Participants, in Association for Inv. Management \& Research, Execution Techniques, True Trading Costs, and the Microstructure of Markets 35 (Katrina F. Sherrerd ed., 1993) (noting that trading is a zero-sum garne in which every trade has one winner and one loser). 
casinos poorer than when they entered. The laws of arithmetic underlie recurrent empirical findings that pension funds and mutual funds trying to outperform the market by trading earn significantly lower inean returns (once trading, research, and manageinent costs are taken imto account) than index funds following a buy-and-hold strategy. ${ }^{30}$

The observation that trading inevitably reduces investors' net wealth does not preclude the possibility that trading inay provide other benefits to investors. Some investors, for example, may trade for hquidity reasons, buying stocks when they wish to invest their accumulated savings and selling when they need to raise cash. Others may willingly incur tradimg costs to "rebalance" their portfohos and to ensure they remain diversified or maintain a certain level of risk. But hquidity needs and portfoho balancing are weak explanations for a secondary market where over half of all shares cliange hands each year. ${ }^{31}$ Part $I I$ examines the substantial evidence suggesting that most trades are, instead, motivated by investors' hopes of trading profits.

If most investors trade to make money, how can their subjective expectations be reconciled with the harsh reality that, on average, trading inakes traders poorer? Scholars often puzzle over why even sophisticated institutional investors like pension and inutual funds seem to believe they can earn positive returns froin trading

30 See Elton \& Gruber, supra note 13, at 710 (stating that index funds outperform most active managers); Wayne $\mathrm{H}$. Wagner, Defining and Measuring Trading Costs, in Association for Inv. Management \& Research, supra note 29, at 15, 17 (noting that active management performance falls between 100 and 150 basis points below index fund performance, i.e., active funds annual earnings' average $1 \%$ to $1.5 \%$ less, due to greater management and trading costs); infra notes 152-68 and accompanying text (examining active and passive management); see also Vanguard Index Trust, Annual Report 1990 at 4 (showing that in the decade ending December 1990, average equity fund saw $10.8 \%$ annual return, whereas S\&P 500 and Wilshire 5000 indexes earned $13.7 \%$ and $12.4 \%$ annual return, respectively).

31 In 1992, the dollar volume of tradiug in U.S. equities on the exchanges and OTC market amounted to nearly $55 \%$ of the market value of all equity holdings. See New York Stock Exchange, Fact Book for the Year 1993, at 89 (1994) (showing total market value of U.S. equities in 1992 as $\$ 5.5406$ trillion); Natioual Ass'n of Securities Dealers, supra note 1, at 7 (showing total dollar volume of trading in U.S. equities in 1992 was $\$ 3.051$ trillion). This figure understates actual turnover, as it excludes private sales that take place outside organized markets. 


\section{despite transaction costs. ${ }^{32}$ Some theorists go so far as to suggest that trading evidences investor irrationality. ${ }^{33}$ Recently proposed}

32 See, e.g., Elton \& Gruber, supra note 13, at 710 (noting that although most active fund managers underperform market indexes, "imvestors who hire active managers believe they can spot the manager who will outperform the imdex"); Kiefer, supra note 10, at 14-15 (noting an "uncomfortable inconsistency" between financial theory and investor behavior in that "[i]nvestors and investment managers who try to increase their rate of return by trading inore actively to take advantage of perceived opportunities for higher profit would discover that, over the longer term, they earn lower rates of return instead"); William F. Sharpe, The Arithmetic of Active Manageinent, Fin. Analysts J., Jan.-Feb. 1991, at 7 (reasoming that the idea that active management allows traders to beat the market "can only be justified by assuming that the laws of arithmetic have been suspended for the convernence of ... active managers").

33 See Hazen, supra note 6, at 992, 1002 (explaining that trying to identify securities that will outperform the market is irrational and not "consistent with the actions of "economic man' "); Kiefer, supra note 10, at 14-15 (suggesting that if investors beheve in the ability to beat the market, mefficient behavior persists on a grand scale, and "a serious reconsideration of some of the most basic principles of economic theory may be necessary"); Stiglitz, supra note 9, at 106 (suggesting that investors' optimistic behief that they can beat the market is "irrationality").

A variant of the irrationality argument loolds that speculators recognize that they dissipate wealth, but trade anyway because they enjoy it. For example, many people seem to enjoy playing a weekly poker game or watching thorouglibreds race at the track; having a stake in the outcome of the contest increases their pleasure and interest. Similarly, some imdividuals may seek entertaininent and involvement in the pages of the Wall Street Journal. Under this theory, both traders and recreational gamblers play negative-sum games because they intrinsically enjoy playing, not because they expect to win.

It is difficult to prove or disprove the claim that investors enjoy squandering their inoney on trading because that proposition is, in effect, a tautology. It assumes that stock trading must make investors better off despite its apparent wealth-destroying nature, because rational actors only pursue activities that make thein better off, and investors are presumed to be rational. As a practical inatter, however, recreation seems an unlikely motive for the dull game of imvesting through the agency of an institution such as a pension or mutual fund (as most imvestors do). Moreover, casual observation suggests that stock traders who sustain steady losses do not find that process enjoyable. See William Glasgall, The Market's Revenge, Bus. Wk., Apr. 18, 1994, at 32, 33 (quoting trader who sustained large losses as saying, "It's no fun."). The notion that investors who speculate willingly accept trading losses as the price one must pay for the joy of "playing the market" is also inconsistent with evidence that traders who sustain losses tend to stop trading. See infra notes 70-79 and accompanying text (describing the "weeding out" process). Finally, whereas recreational gambling sometimes is explamed by risk-preference, the natural volatility of the stock market ensures that instead of trading, risk-preferring investors can more cheaply satisfy their tastes by buying and holding high-risk stocks. Thus, although it is possible that some investors trade for enjoyment despite their recognition that they are likely to lose money, the "recreational trading" argument seems a weak foundation on which to build a three trillion-dollar-a-year trading inarket that is heavily dominated by imstitutions. See also infra notes 309-12 and accompanying text (suggesting that some gambling is not recreational but, like stock trading, is a market failure arising from lieterogeneous expectations). 
"noise trader" models of stock markets, for example, presume that substantial numbers of those who participate in equities markets are irrational. ${ }^{34}$

Such a radical departure from traditional economic analysis may be unnecessary to explain stock markets. A rational choice model of stock speculation can be developed that reconciles the phenomenon of negative-sum trading with the assumption that investors are self-interested actors who make the best possible use of the resources available to them. This "heterogeneous expectations" model rests on the key premise that investors can rationally differ in their estimates both of stocks' likely future performance and of their own relative tradimg abilities. On this plausible foundation can be built a model that offers miportant imsights imto who trades stocks, why, and for how long; the relationship between stock prices and best estimates of values; and the mamier im which stock markets might be regulated to maximize their social benefits while minimizing their costs.

\section{B. A Simple Model of Heterogeneous Expectations and $H E$ Trading in a World of Imperfect Information}

On average, imvestors who abandon buy-and-hold strategies and try to increase their returns through trading find that their expectations of profits from trading were mistaken. But to say that an investor may be mistaken does not necessarily imply that she is irrational. Even the most sensible actor may make mistakes, if she lacks perfect information. ${ }^{35}$ Thus, the consumer who does not know at the time of purchase that a used car needs $\$ 200$ in repairs

34 See, e.g., Fischer Black, Noise, 41 J. Fin. 529, 531, 534 (noting that because "noise" traders trade "even though from an objective point of view they would be better off not trading," their behavior does not fit "into a world where people do things only to maximize expected utility of wealth, and where people always make the best use of available information"); De Long et al., Noise Trader Risk, supra note 10, at 735 (noting that noise theory focuses on irrationality in financial markets); J. Bradford De Long, Andrei Shleifer, Lawrence H. Summers \& Robert J. Waldmann, The Size and Incidence of the Losses from Noise Trading, 44 J. Fm. 681 (1989) [hereinafter De Long et al., Losses from Noise Trading] (concluding that noise trading is irrational); Andrei Shleifer \& Lawrence H. Summers, The Noise Trader Approach to Finance, J. Econ. Persp., Spring 1990, at 19 (stating that noise traders are "not fully rational").

${ }^{35}$ See generally Alan Schwartz \& Louis L. Wilde, Intervening in Markets on the Basis of Imperfect Information: A Legal and Economic Analysis, 127 U. Pa. L. Rev. 630 (1979) (examining judicial and legislative responses to imperfect information in the market for 
might mistakenly pay $\$ 5,000$ for a vehicle that she would value at $\$ 4,800$ if she had perfect information.

Rational individuals are willing to risk making mistakes by acting on imperfect information because information is costly. It inay be cheaper for a consumer to bear the risk of buying a car with a $\$ 200$ defect than to pay a inechanic $\$ 300$ to inspect the car. Similarly, investors evaluating the likely future performance of particular stocks may consider a wide variety of data, including the firm's annual reports, past price performance, or media accounts of the company or the general econoniy. But because gathering and digesting data takes time and money, at some point the cost of acquiring additional guidance (by reading another report or hiring a professional analyst, for instance) outweighs the risk of purchasing an overvalued stock. ${ }^{36}$ Rational investors weigh the potential price of ignorance against the certain expense of further research and nuake the best decisions they can.

Different investors are likely to face different costs in obtaining and using different subsets of information relevant to stock values. An accountant may find it easiest to gauge a coffee conipany's prospects according to its financial statements, whereas a gourinand who hates numbers niay judge the firm by the taste of its product. $^{37}$ Investors who rely on different subsets of information are likely to form different opimions of the likely risks and returns

consumer goods); George J. Stigler, The Economics of Information, 69 J. Pol. Econ. 213 (1961) (discussing economic decisions when information is imperfect and costly).

36 Because stock valuation requires investors to predict an inherently uncertain future, at some point the cost of acquiring all information relevant to stock values becomes infinite.

37 The taste of Dunkin' Donuts coffee allegedly was one of the factors that induced legendary mutual fund manager Peter Lynch to invest in that firm's stock. Carolyn Friday, A Superstar Bids Farewell, Newsweek, Apr. 9, 1990, at 38. 
of particular stocks. ${ }^{38}$ These heterogeneous expectations can easily motivate the negative-sum game of stock trading. ${ }^{39}$

Consider the following scenario. A Wall Street Journal article praising General Motors' efforts to trim costs convinces John that GM's market price will soon rise from $\$ 100$ to $\$ 105$ per share. Mary, a GM shareholder, has different information-her newly purchased GM car is a lemon, and she expects GM stock to dechne to ninety-five dollars. Even if John and Mary each must pay two dollars per share im broker commissions to trade, each perceives an opportunity to profit from trading. John anticipates a quick net gam of three dollars per share if he buys, whereas Mary expects to avoid a net three dollars per share loss if she sells. Whether GM rises or falls, trading costs ensure that one party's wealth loss outweighs any wealth gain enjoyed by the other. If GM rises to $\$ 105$, John earns his expected net three dollars per share profit, but Mary loses a net seven dollars per share. Similarly, if GM falls to ninetyfive dollars, Mary saves a net three dollars per share, but John loses seven dollars per share. Although John's and Mary's asymmetrical expectations leads each to perceive an ex ante opportunity to gain three dollars per share (six dollars per share total) from trading,

38 See Black, snpra note 34, at 531 ("Differences in beliefs must derive ultimately from differences in information."). Soine commentators have suggested that investors with access to the same information still reach differing conclusions because each individual has unique ways of processing information. E.g., Stephen Figlewski, Market "Efficiency" in a Market with Heterogeneous Information, 86 J. Pol. Econ. 581, 584-85 (1978); Milton Harris \& Artur Raviv, Differences of Opinion Make a Horse Race, 6 Rev. Fin. Stud. 473, 474 (1993) (stating that "disagreements can arise either because speculators liave different private information or because they simply interpret commonly known data differently"). Such arguments make a distinction without a difference. Different individuals may disagree in their interpretations of the same information because their differing experiences and training liave taught thein to extract different meanings. Yet experience and training inevitably are part of the "information" brought to bear on the problem of stock valuation.

39 It is important to distinguish heterogeneous expectations from botll lieterogeneous preferences and siniple uncertamty. If both John and Mary agree that the price of GM stock lias a $25 \%$ clrance of falling by $\$ 1$, a $25 \%$ chance of rising by $\$ 1$, and a $50 \%$ clrance of remaining the same, then they face uncertainty but share the same expectations. Alternatively, if John and Mary share these expectations about the future performance of GM, but John likes risk whereas Mary is risk-averse, then John may want to buy and Mary to sell, because although they sliare similar expectations, they liave different preferences for risk. See infra note 142 . 
their transaction inevitably reduces their aggregate wealth by four dollars per share ex post. ${ }^{40}$

As this example illustrates, a purely speculative inarket of traders betting on their differing predictions for the future is, in a sense, a inistaken market, for traders on average lose money by trading. Yet such waste is not necessarily due to individual irrationahity. John's and Mary's decisions to trade were quite rational, given their differing expectations. ${ }^{41}$ Their net loss can be blamed on imperfect information. After all, in a world of perfect information both John and Mary would know whether GM were going to rise or fall. No sale would occur because, if GM were going to rise, John would want to buy at market price but Mary would refuse to sell, whereas if GM were going to fall, Mary would be eager to sell but John would balk at buying. In a world of imperfect inforınation, however, John and Mary can disagree on GM's likely future and each perceive an opportunity to gam wealth by trading. At least one will be wrong. ${ }^{42}$

Economists writing on the economics of inforination have long observed that heterogeneous expectations can induce rational, wealth-seeking actors to pursue activities with negative expected returns. ${ }^{43}$ Contemporary securities scholars, however, have largely

\footnotetext{
40 See Stiglitz, supra note 9, at 106 (noting that stock trades may appear efficient ex ante yet actually reduce trader welfare ex post).

41 A body of work in game theory posits that it is irrational to trade on the basis of heterogeneous expectations. See, e.g., Robert J. Aumann, Agreeing to Disagree, 4 Annals Stat. 1236 (1976); John D. Geanakoplos \& Heraklis M. Poleınarchakis, We Can't Disagree Forever, 28 J. Econ. Theory 192 (1982); Paul Milgrom \& Nancy Stokey, Information, Trade and Common Knowledge, $26 \mathrm{~J}$. Econ. Theory 17 (1982). The no-speculation theorems do not account for the phenomenon of learning, however, and also depend on strong assumptions about common knowledge and imvestor homogeneity. See Lynn A. Stout, Agreemg to Disagree over Excessive Trading, 81 Va. L. Rev. 751 (1995); see also Jeremy C. Stein, Informational Externalities and Welfare-reducing Speculation, 95 J. Pol. Econ. 1123, 1125 (1987) (noting that in market with inperfect information, traders who trade on misinformation are still rational).

42 Indeed, both parties may conclude that their trade was mistaken if prices do not change enongh to let at least one profit despite trading costs. Suppose John buys GM expecting it to rise by at least $\$ 3$ per share, so that he can earn at least $\$ 1$ net after paying $\$ 2$ in broker commissions. Mary sells anticipating GM will fall by $\$ 3$. If GM rises by only $\$ 1$, both will be disappointed.

43 For example, the literature on the economics of research and invention has long recognized the possibility of social waste due to a dnplicative "rush to invent" by competing innovators all of whom expect to be the lucky one to win a patent. See, e.g., Hirshleifer, supra note 12, at 187-90 (discussing rush to invent and noting that similar
} 
overlooked that hiterature's obvious implications for securities markets. This may be because orthodox financial theory generally assumes for converience that imvestors are perfectly informed and share identical expectations. ${ }^{44}$ In the real world, however, investors labor under conditions of both ignorance and disagreement. A stock trading model that recognizes this reality yields important insights into the behavior of markets and the individuals and entities who participate in them. It also offers a picture of equities markets that in many respects differs strikingly from the one painted by conventional theory, which portrays stock markets as highly efficient capital-allocatimg machines in which all securities are accurately priced and all trades serve traders' self-imterests. ${ }^{45}$

HE theory predicts that when investors hold differmg opinions of stock values, some will inevitably disagree with the market price for a firm's shares. ${ }^{46}$ An investor's decision to buy or sell because her personal estimate of a particular stock's value differs from its

problem may exist for stock market research, where social benefits are negligible while private pecuniary returns are substantial); Jack Hirshleifer, The Private and Social Value of Information and the Reward to Inventive Activity, 61 Am. Econ. Rev. 561 (1971) [hereinafter Hirsleifer, Value of Information] (observing that "inhomogeneous beliefs" regarding the effect of information on the value of their respective speculative positions miglit motivate individuals to "willingly cooperate in making expenditures far in excess of the social value of the information to be acquired"); see also Frank H. Easterbrook \& Daniel R. Fischel, Mandatory Disclosure and the Protection of Investors, 70 Va. L. Rev. 669,682 n.21 (1984) (noting similar observations in public choice literature on rentseeking).

44 See infra note 117 and accompanying text (citing the hoinogeneity assumption). The hoinogeneity assunuption inay explani why financial theorists and securities scholars so often overlook the inportance of investor disagreement to understanding secondary stock markets. See, e.g., sources cited supra notes 32-33 (noting that economists are puzzled by traders' behef that they can beat the inarket); supra notes 105-112 and accompanying text (citing scholars puzzled by markets' fundaniental value inefficiency).

45 See Summers \& Summers, supra note 8, at 263 (contrasting "the Panglossian, theoretical, efficient narkets view of the operation of financial markets" with "the way they work in practice").

46 When investors hold heterogeneous expectations, a stock's Inarket price is determined by the price deinanded by the most pessinistic of the firm's current shareholders, i.e., the shareholder willing to accept the lowest price to part with her shares. See infra notes 122-127 and aceolnpanying text. 


$$
-1
$$


shares in Firm $\mathrm{X}$ are currently trading at market price $\mathrm{P}_{\mathrm{x}}$ per share. Based on the limited information reasonably available to her, an investor concludes that $\mathrm{P}_{\mathrm{x}}$ does not accurately reflect the value of $X$ 's stock, which the imvestor estimates to be $V_{x}{ }^{48}$ The estimated transaction costs of buying or selling one share in $X$ are $T_{x}$. The imvestor will perceive opportunities to profit by buying $X$ whenever $\left(V_{x}-T_{x}\right)>P_{x}$, or by selling (or selling short) whenever $\left(V_{x}+T_{x}\right)<$ $\mathrm{P}_{\mathrm{x}}$. More generally, the imvestor will perceive an opportunity to make money by trading whenever the difference between market price and the investor's estimated value exceeds the estimated cost of trading, so that $\left|P_{x}-V_{x}\right|>T_{x}$.

This modest formula permits two important observations. First, the more widely dispersed investors' opimons, the more likely it is that speculative HE trading will occur, other things being equal. ${ }^{49}$

relatively few investors subjectively value any particular stock more than its market price plus transaction costs.

48 The market price of a stock is by definition an accurate measure of that stock's value if it has to be sold immediately. If an investor expects that a particular security will, over time, either show less risk or provide greater returns in the form of dividends and capital appreciation than reflected in the current price, however, the investor may be able to profit by buying the stock and holding it for some period.

INCREASING THE DISPERSION OF INVESTOR EXPECTATIONS

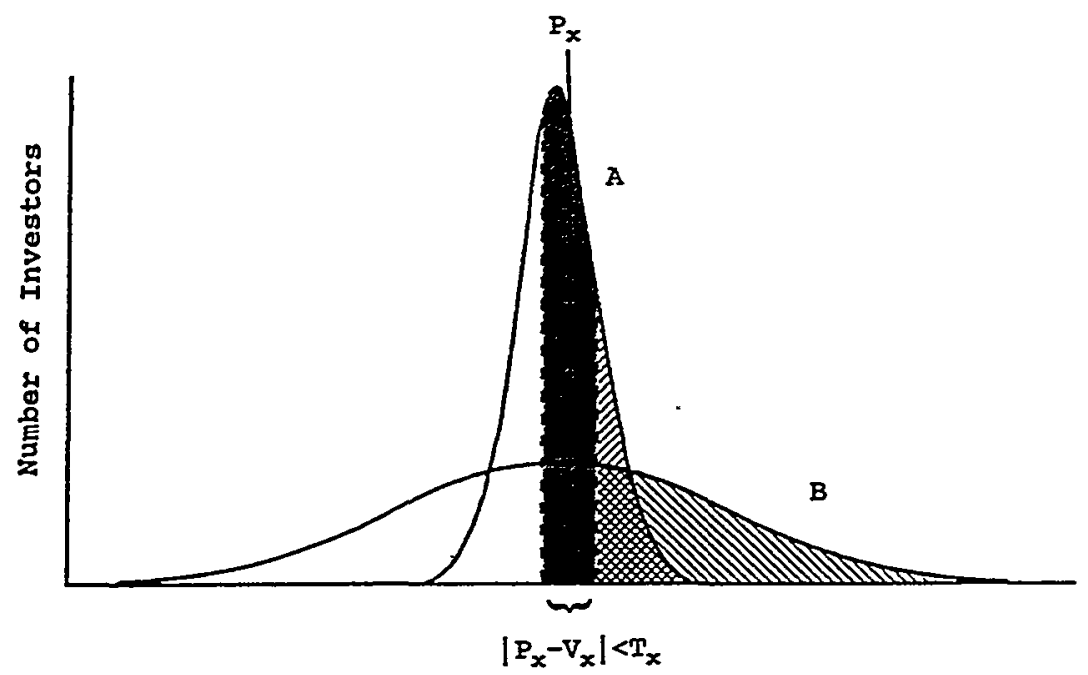


In other words, investors are more hikely to perceive opportunities to profit despite trading costs when their subjective valuations of stocks differ greatly from market prices (when $\left|P_{x}-V_{x}\right|$ is large). ${ }^{50}$ Second, even a modest dispersion in imvestor valuation creates perceived opportunities to profit from speculation when tradimg costs $\left(\mathrm{T}_{\mathrm{x}}\right)$ are low. ${ }^{51}$

Figure 2 shows how an increase in the dispersion of investors' subjective estimates will increase trading activity. As in Figure 1, the darkly shaded area depicts the area in which no tradiug will occur because of prohibitive transaction costs $\left(\left|P_{x}-V_{x}\right|<T_{x}\right)$.

The areas under curves $A$ and $B$ are equal, reflecting a fixed pool of investors. However, curve B represents a pool of investors who exhibit a much wider variation in their subjective valuations than the pool of investors represented by curve A. Again, as in Figure 1, in both curve $A$ and curve $B$ the area to the right of the darkly shaded area represents the area where investors regard the stock as a worthwhile purchase. Note that this trading area is greater under curve B than under curve A; more trading will occur in the pool of investors with more widely dispersed subjective valuations. "Similarly, the darkly shaded nontrading area is greater under curve $A$ than under curve $B$, indicating that transaction costs deter more trades when investors' expectations are relatively homogeneous.

50 Professors Milton Harris and Arthur Raviv theorize that when traders start with common beliefs about an asset's expected returns, trading occurs when, and only when, new information changes their minds. As a result, volume and changes in price are positively correlated, as are changes in earnings forecasts and volume. Harris \& Raviv, supra note 38 , at $474-75$; see also id. at 478 (citing and discussing the "fairly abundant" enpirical studies that support these theoretical conclusions).

51

Figure 3:

InCREASING TRANSCATION COSTS

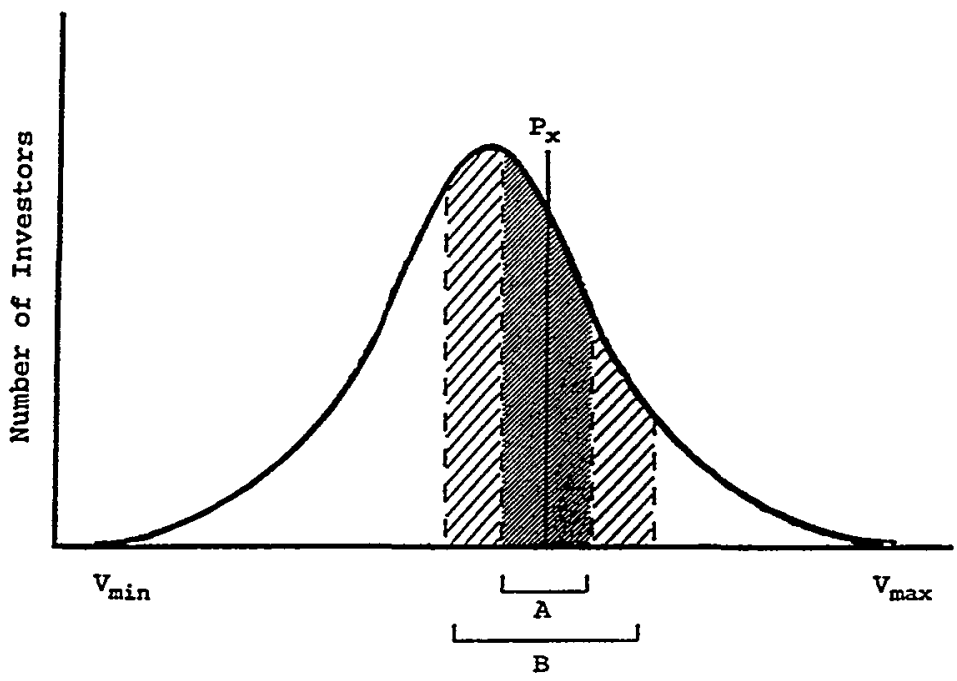

Subjective Valuation 
As a practical matter, modern stock markets exhibit both wide dispersion in investors' opinions and low transaction costs. The pages of Business Week and the Wall Street Journal are replete with anecdotal evidence that people often disagree wildly in their predictions for stocks and the market as a whole. ${ }^{52}$ Empirical studies confirm that investors' subjective estimates of stock values vary greatly. One recent study, for example, found that corporate offers to repurchase shares from shareholders at prices averaging thirteen percent over market price induced shareholders on average to tender only eighteen percent of their outstanding shares, ${ }^{53}$ suggesting that eighty-two percent of shares were held by investors in whose opinions their stocks' values exceeded the market price by more than thirteen percent. ${ }^{54}$ Such findings should come as no surprise. Because stocks represent claims to future incoine in the form of either dividend payments or capital appreciation, stock values depend upon an inherently uncertain future. ${ }^{55}$ Any investor

Figure 3 depicts how increasing trading costs will decrease trading. Increasing trading costs from range $A$ to range $B$ will expand the nontrading area within which investors perceive that transaction costs outweigh potential gains from buying or selling a stock they perceive as mispriced. A difference between subjective valuation and inarket price that would have resulted in a trade given initial trading cost $\mathrm{A}$ may now be inadequate to overcoine greater trading cost $\mathrm{B}$.

52 See, e.g., Fred R. Bleakley, One Set of Economic Facts, Two Views: Forecasts of Growth and Inflation Vary, Wall St. J., Apr. 25, 1994, at A2 (describing economists' expectations for growth as "widely divergent"); Jeffrey M. Laderman, Tiptoeing Through Uncertain Times, Bus. Wk., Dec. 26, 1988, at 92 ("If you're confused about what to do with your money in 1989, you're in good company. Professional opimon is all over the lot ....."); Steven E. Levingston, Adherents of the Dow Theory on Stock Trends Disagree Over When Bull Market Will End, Wall St. J., Feb. 1, 1993, at C1 (describing investors who subscribe to the Dow Theory as unable to agree on when bull inarket will end).

53 Laurie S. Bagwell, Dutch Auction Repurchases: An Analysis of Shareholder Heterogeneity, 47 J. Fin. 71, 76 tbl. 1, 97 (1992) (presenting results and arguing that evidence does not support claim that premium is due to signaling effect of offer but rather that "[s]hareholders' valuations differ dramatically").

54 The notion that an investor might value stock in a particular firm at $13 \%$ over inarket price naturally raises the question of why, given reasonably low trading costs, the investor does not purchase more shares until eventually she drives the inarket price up to match her own subjective valuation. The answer is that any single investor's ability to affect market price is limited by both that investor's wealth and her willingness to tolerate risk froun reduced portfoho diversification. See infra notes 122-27 and accounpanying text (discussing setting market price in inarket of heterogeneous expectations).

55 Investors usually can profit froin stocks only through dividends or capital appreciation, both of which depend on future events. An exception arises when an investor seeks to profit by buying a controlling block of shares in an undervalued firm and then liquidating the firm and selling off its assets. See generally Remier Kraakman, Taking 
trying to predict that future could consider an almost infinite number of factors, including the quality of a firm's management, its competitors, its products, prevailing interest rates, exchange rates, macroeconomic growth, tax rates, demographic changes, and even the weather. Given the costliness of any single investor's acquiring and assimilating more than a small fraction of the vast data relevant to stock price, "the dark forces of time and ignorance"56 ensure that investors' subjective estimates of stock values will vary considerably.

Modern stock markets also offer low transaction costs. For example, stock traders often pay one percent or less of the value of their trades in broker commissions. ${ }^{57}$ In comparison, the homeowner who sells a simgle-family residence may pay seven percent in real estate agent commissions. ${ }^{58}$ Trading costs in modern stock markets are low compared not only to the costs of trading many other assets but also to historical costs. Before 1968, NYSE-1nember firms enforced a comprehensive scheme of fixed minimum broker commissions that ensured that investors paid inuch higher broker fees than they do today..$^{59}$ The fixed commission structure was eliminated gradually between 1968 and $1975 .{ }^{\circ 0}$ Congress also

Discounts Seriously: The Implications of "Discounted" Share Prices as an Acquisition Motive, 88 Colum. L. Rev. 891 (1988) (exploring possibility that some corporate acquisitions are motivated by perception that the market price of a firm's equity is less than the value of the firm's assets).

56 Keynes, supra note 10, at 155.

57 See Hans R. Stoll, Equity Trading Costs 14 tbl. 4 (1993) (finding from securities firms' revenue data for 1990 that average investor paid commissions amounting to approximately $0.29 \%$ of value of trade on exchanges and $0.43 \%$ of value on OTC market); cf. Kiefer, supra note 10, at 24 (noting that for largest trades by largest institutions, broker commissions estimated to be between $0.05 \%$ to $0.18 \%$ of value of shares traded).

Broker commissions are, however, just one of the many costs associated with speculative trading. An estimate of the total costs of speculative trading to investors based on mutual funds' expense ratios suggests that in 1992 investors spent $\$ 100$ billion researching, managing, and trading equities portfohos, a cost that amounts to approximately three percent of the total of $\$ 3.06$ trillion im stocks traded. See infra notes 193-207 and accompanying text (discussing the $\$ 100$ billion cost); supra note 1 and accompanying text (noting $\$ 3.06$ trillion traded).

58 See Schwert \& Seguin, supra note 8, at 21 (noting seven percent real estate costs). Not surprisingly, turnover in single-family homes is only a fraction of turnover in stocks. See Tobim, supra note 10, at 4 (noting the $4.5 \%$ annual turnover in single-family homes).

59 See Kiefer, supra note 10, at 22. See generally 6 Loss \& Sehgman, supra note 16, at 2831-85 (discussing brokerage commission rate regulations).

60 Kiefer, supra note 10, at 22. 
repealed a modest federal stock transfer tax in $1965,{ }^{61}$ while New York state abolislied a similar tax in $1981 .^{62}$ The resulting decline in stock trading costs $^{63}$ las been accompanied by draniatic increases in trading volume: between 1960 and 1987, the turnover rate of shares on the NYSE increased from about ten percent to approximately fifty percent annually ${ }^{64}$

\section{Potential Deterrents to HE Trading: The Roles of Self- Selection and Successive Generations in Fostering Speculative Markets}

The simple HE model presented above suggests that investors lacking perfect information form leterogeneous expectations that make speculative trading a rational, if ultimately self-defeating behavior. Altliough HE trading only occurs in favorable circumstances-when significant dispersion in investor expectations is combined with low trading costs-modern stock markets provide exactly the conditions necessary for HE trading to flourisl.

This simple HE model, however, neglects two influences that should discourage $\mathrm{HE}$ trading even when investors hold widely differing views of stocks' merits and face minimal trading costs. The first deterrent to HE trading is the rational imvestor's recognition that $\mathrm{HE}$ trading is, statistically speaking, a loser's ganie. Investors who disregard that deterrent and attempt to trade profitably will eventually be faced witl a second deterrent, the lessons of bitter experience. A persuasive model of stock trading based on heterogeneous expectations consequently must explain how speculative markets can prosper in the face of both speculation's obviously negative-sum nature and investor learning. ${ }^{65}$

611 Loss \& Seligman, supra note 16, at 329 n.18.

62 Kiefer, supra note 10 , at 23.

63 As a result of these clianges, institutional traders' out-of-pocket trading costs lave declined to less than half of their costs in the mid-1960s and 1970s. See id. at 24.

64 Id. at 6 fig. 1; see also Scliwert \& Seguin, supra note 8, at 19 (citing studies estimating that average commission rates fell by $30 \%$ from 1975 to 1978 , accoinpanied by $30 \%$ increase in trading volume from 1975 to 1981); Steplien A. Berkowitz \& Dennis E. Logue, The Portfolio Tumover Explosion Explored, J. Portfolio Mgmt., Spring 1987, at 38, 44 (finding historical increase in turnover to be "closely related to the declining trend in trading costs").

65 A third deterrent to speculative trading is nearly three decades of financial theoreticians' warnings that "you can't beat the market." According to one version of efficient market theory, stock prices should reflect the best possible estimates of values and 


\section{Optimistic Self-Selection and the Lake Wobegon Market}

Because they lack perfect information concerning stock values, investors can rationally disagree with market prices and perceive opportunities to profit from trading in mispriced stocks. Yet rational investors who stop to think about the negative-sum nature of stock trading should also readily recognize that traders, on average, lose wealth by trading. Why would even the most bullislı or bearish investor try lier liand at trading once she recognizes that the odds are stacked against her?

In fact, inany do not trade. Many individual and institutional investors choose a passive buy-and-hold strategy. ${ }^{66} \mathrm{But}$ as long as a subset of investors chooses to trade, a speculative market can flourish. An important insight of the HE model is tliat self-selection can sustain speculative markets even when it is apparent to all participants tliat speculation is negative-sum.

When sonie nivestors hold high opinions of their own abilities to "buy low and sell higlı" whereas others are nore pessimistic about their trading talents, only the optimists trade. Humble John may perceive General Motors shares to be mispriced but niay also hesitate to trade on this perception because he recognizes his analysis is based on inperfect information and that trading, on average, erodes investor wealth. In contrast, self-confident Mary may also know that traders on average lose noney but believe that she has better-tlran-average ability to pick stocks. John will hew to a buyand-hold strategy, whereas Mary will test her stock-picking skills by buying those stocks she perceives as underpriced and selling those slie perceives as overpriced.

present no opportunities for arbitrage profits. See infra notes 93-100 and accompanying text. The HE model, however, supports market participants' claims that efficient markets can misprice stocks. See infra notes $128-32$ and accompanying text. Self-selection also helps explain why traders continue to bet on their bullish and bearish behiefs despite theorists' warnings: even if the vast majority of investors behieved the vast majority of stocks to be accurately priced, so long as a minority beheved that a small portion of the thousands of publicly traded stocks were sufficiently mispriced to justify minimal transaction costs, HE trading would occur.

66 For example, nearly $20 \%$ of all assets held by peusion plans are indexed. See infra note 162. Indexed stock mutual funds also are becoming more popular. See generally Elton \& Gruber, supra note 13, at 705 ("Funds under passive management have grown rapidly and reached significant size."). 
Self-selection thus plays a key role in determining who participates in speculative trading. Speculative inarkets are "Lake Wobegon" markets, where all traders believe their trading skills are above average. ${ }^{67}$ Imperfect information easily reconciles such mistaken beliefs with rationality ${ }^{68}$ althougli investors may liave perfect information concerning the average trader's negative returns, they remain ignorant of their likely personal returns until they try their liands at the trading gaine. Individuals who have enjoyed success in otlier personal and professional endeavors may reasonably approach the stock market with an optimistic faith im their own abilities. ${ }^{69}$ They also necessarily enter the market ignorant of their own relative trading talent. Only time and experience will reveal whether they are winners or waslouts.

The HE model of trading tlius suggests that speculative markets reflect two forms of investor mistake: mistakes about stock values and mistakes about relative trading skills. But as long as investors face positive information costs in evaluating botlı stocks and their own trading talents, self-selection ensures tliat a subset of imvestors-the financially sophisticated, the personally successful, or the merely liopeful-will try the trading gaine on the rational but statistically mistaken belief that they are better, briglter, or luckier than their fellow traders.

\section{A Longitudinal Model of HE Trading: Darwin Meets Barnum}

Altliougl self-selection explains wliy a subset of rational mvestors miglit elect to play a single rolmd of tlie negative-sum gaine of

67 Comedian Garrison Keillor described his fictional hometown, Lake Wobegon, as a place where "all the children are above average." Garrison Keillor, Leaving Home xvii (1987); see also Ronald C. Lease, Wilbur G. Lewellen \& Gary G. Schlarbaum, The Individual Investor: Attributes and Attitudes, 29 J. Fin. 413, 431 tbl. 7 (1974) (finding that a study group of investors on average beheved itself to be "substantially better informed than the average investor").

$68 \mathrm{Cf}$. Stiglitz, supra note 9, at 106 ("It is only because each individual believes that lie or slie is smarter than other speculators-a proposition tliat cannot be 'ratioually' leeld by all-that the market survives at all.").

69 Interestingly, it is the educated and personally successful who most often appear on brokers' "sucker lists" and who, at least in folklore, are most often the victims of excessive stock trading. See Lowenstein, supra note 10, at 16 (discussing "sucker lists"); Stightz, supra note 9, at 105 (describing dentists and doctors as classic mistaken "noise traders"). Such individuals liave in common both relative wealth and the tendency to be "self-made" men and women who may be particularly likely to overestimate their own talents and trading abilities. 
stock trading, repeated plays should create selection pressures that lead speculative stock inarkets eventually to evolve into inarkets where investors trade only for hquidity or similar non-speculative reasons. ${ }^{70}$ In other words, investor learning should provide a second deterrent to speculative trading.

Imperfect information about relative game-playing skill allows each of the self-selected participants in a negative-sum game like stock trading to believe they are more likely to win than the next player. Over time, lowever, actors wlio play a series of games gain additional information about their relative skill in playing. Winners learn that they are winners and presumably will continue to play. But soine of those who play negative-sum games learn they were mistaken in thinking they would win. In the face of mounting losses, it is only rational for those who lose at negative-sum games eventually to decide to forgo playing. With whom, then, will the winners play?

One possible answer is that as the initial losers exit the game, the initial winners are left to play with each otler. On this model, repeated stock trades should result in sinaller and sinaller numbers of willing traders who enjoy higher and higher average levels of skill. Taken to its logical extreme, this "survival of the fittest" model predicts that a speculative inarket should eventually be dominated by a single trader who is so successful no one is willing to bet against her.

This model obviously fails to describe modern stock markets, although Wall Street does have its legendary winners. For example, before his early and lamented retirement, renowned mutual fund manager Peter Lynch parlayed the Magellan Fund from \$20 million in assets into a $\$ 13$ billion leviathan that beat the Standard \& Poor's 500 index in all but two of Lynch's thirteen years at the

70 See infra Part II.A (discussing nonmistaken reasons for trading); cf. Figlewski, supra note 38, at 596 ("TT] weeding-out process over time by which those with inferior information gradually lose money to those whose information is better ...."); Keynes, supra note 10, at 154 ("It might have been supposed that coinpetition between expert professionals, possessing judgmeut and knowledge beyond that of the average private investor, would correct the vagaries of the ignorant individual ...."); De Loug, et. al., Noise Trader Risk, supra note 10, at 704 (noting argument that traders with poor judgments of asset values lose inoney and eventually disappear from the market); Stiglitz, supra note 9, at 106 (discussing argument that noise traders will lose inoney and eventually be "weeded out" of the market). 
helm. ${ }^{71}$ Yet Peter Lynch in his heyday controlled only a sinall portion of the market; millions of other individuals and institutions willingly traded against him. Any theory of $\mathrm{HE}$ stock trading must explain how speculative markets persist when repeated trading reveals information that should dissuade at least a portion of traders from continuing to trade. Some process must be inducing individuals to continue to play even against proven winners.

As P.T. Barnum suggested, deinographics provides an answer. ${ }^{72}$ Stock narkets have existed in one form or another for centuries and have served successive generations of investors. As each generation ages, it accumulates wealth that it eventually seeks to invest. Stocks are attractive investments; even with a buy-and-hold strategy, investors can expect to enjoy greater returns froin stocks than froin corporate bonds, government bills, or bank deposits. ${ }^{73}$ Many new stockholders remain cautious and follow a buy-and-hold approach rather than risk losses through trading. But in each new generation, a subset of mvestors will judge that they are better at picking stocks than their fellow traders. Their optinnistic assessments of their own abilities lead thein to try their hand at speculative trading. As they play the market, they learn about their relative skill in trading. Most learn they are losers and eventually either exit the market or fall back on a buy-and-hold strategy.

71 Friday, supra note 37, at 38. Another famous winner is George Soros, "the most powerful and successful investor in the world." Gary Weiss \& Gail E. Schares, The Man Who Moves Markets, Bus. Wk., Aug. 23, 1993, at 50. A Holocaust survivor who once supported himself by working as a waiter, Soros estabhshed the Quantum Fund in 1969. Id. at 53, 56. From its inception though 1993, Quantum realized an average annual 35\% return, with only one down year. Id. at 52-53.

It is possible, of course, that both Lynch and Soros were gifted with luck rather than skill. Even if mvestors cannot identify mispriced stocks, their returns from stock ownership are likely to be randomly distributed, and some lucky mvestors will strike it big just as others unaccountably lose big.

72 P.T. Barnum is credited with the observation that "[t]here's a sucker born every minute." John Bartlett, Familiar Quotations 460 (Justin Kaplan ed., 16th ed. 1992). HE theory suggests a less elegant but inore accurate and generous version: "there's a rational optimist who is imperfectly informed about her relative trading ability born every minute." Cf. Stightz, supra note 9, at 106 (noting view that in market of traders irrationally trying to beat the market, losers should eventually be "weeded out," but observing that "[f]or every fool that is weeded out, a new one enters the market").

73 Brealey \& Myers, supra note 13, at 126 tbl. 7-1 (showing average rates of returns on common stocks, corporate bonds, governmeut bonds, and Treasury bills from 1926 to 1985). 
Consistent winners continue to trade and to profit from the mistakes of a new generation of investors.

This longitudimal model of HE trading implies that speculative markets are likely to be composed of a small number of highly successful, wealtliy traders who remain in the market over a long period of time and a larger number of recently arrived, smaller traders whose trading time is likely to be short-lived and who will stop trading after losing money. In fact, exactly this pattern of Darwinian attrition is evident among stock inutual fund inanagers. ${ }^{74}$ Less than fifteen percent of actively managed mutual funds have been under the control of the same imdividual for ten or more years. ${ }^{75}$ Those funds tend to outperform the market, and they hold average assets of over $\$ 1977$ million. $^{76}$ In contrast, inutual funds with managers of less than ten years' tenure are both smaller and less successful; on average, they underperform the market and have assets of only $\$ 822$ million. ${ }^{77}$ Similar patterns are found in futures inarkets, where a small number of large traders obtain positive returns while a large number of smaller traders suffer losses. ${ }^{78}$ Such patterns accord with the prediction that speculators learn

74 There is evidence of Darwinian attrition among individual investors as well. Since 1980 , about the time that inutual funds became popular alternative investment vehicles, interest in individual stock ownership has tended to be concentrated among relatively young, and presumably inexperienced, investors. See New York Stock Exchange, supra note 31, at 86 (noting that in 1985, there were 11.1 million individual shareholders aged 21$34 ; 11.0$ million aged $35-44 ; 7.9$ million aged $45-54 ; 8.2$ million aged $55-64$; and 6.6 million aged 65 and over). Because wealth and savings tend to increase with age, see infra note 171 , one would expect to see individual stock ownership increase rather than decrease with cohort age-unless, as HE theory predicts, there is investor attrition due to learning. If so, individual ownership of stocks might decrease with age because individuals learn over time that they are not successful at stock-picking and shift their investments into mutual funds instead.

75 This figure is calculated froin a recent survey of 760 equity funds that included information on management tenure, assets, and performance. See Jeffrey M. Laderman, The Best Mutual Fimds, Bus. Wk, Feb. 14, 1994, at 72, 78-103.

76 Id.

77 Id.

78 Lester G. Telser, Why There Are Organized Futures Markets, 24 J.L. \& Econ. 1, 10 (1981) (citing studies deinonstrating that large traders tend to obtain positive returns from futures whereas small traders suffer losses, implying that turnover is greater among sinall traders because successful traders will becoine large while unsuccessful traders will leave the inarket and be replaced by new small traders hoping for success); see also Hazen, supra note 6, at 1006 (noting the "consensus" that in derivatives inarkets "the winners are relatively few in number, and ... smaller, less sophisticated investors are usually the losers" (citation omitted)). 
over time whether they are winners or losers, and losers rationally seek to preserve their wealth by exiting the trading inarket. But because each generation must begin anew the process of separating winning traders from losers, speculative markets persist in the face of investor learning. ${ }^{79}$

\section{The Role of Financial Intermediaries In Encouraging HE Trading}

The discussion thus far has proceeded as if stock markets consisted largely of individuals trading directly with each other. In reality, investors who trade in modern inarkets often use the services of a wide variety of financial intermediaries. The HE model suggests that at least two common forms of intermediaries, brokers and institutional investment funds, are likely to increase the imcidence of HE trading significantly.

\section{The Role of Brokers}

The simple trading formula presented earher predicts that, ceteris paribus, increasing the dispersion of investor expectations mcreases the incidence of trading. Given the difficulty of predicting the future, investors' opinions of stocks' relative values will naturally diverge. Yet the dispersion of investor opimion may be increased further by the efforts of a class of intermediaries with substantial incentive to convince investors they can profit through trading. Enter the brokers.

79 Noise theorists have hypothesized that irrational noise traders persist in the market because their trading adds variability to prices that occasionally allows noise traders to reap profits rational traders cannot. See generally Black, supra note 34, at 532 (arguing that insofar as noise traders distort market prices, they add risk to the market that keeps away enough informed traders to allow imperfect pricing to persist); De Long et al., Losses from Noise Trading, supra note 33, at 685-86 (developing model in which noise traders can earn better returns than rational investors and so persist in market because noise trading adds risk to existing fundamental risk); Figlewski, supra note 38, at 595-597 (arguing that participation of less-informed traders noves prices away from efficient level); see also Keynes, supra note 10, at 154, 156-58 (arguing that expert professionals will not necessarily profit and prevail because irrational sentiment's effect on the market leads even professionals to focus on crowds' behavior rather than fundamentals to avoid short run losses).

Such arguments are plausible but hardly necessary to address the "weeding out" issue. Generational demographics suggest a far more direct and simple answer. Cf. De Long et al., Noise Trader Risk, supra note 10, at 718 (“Under the P.T. Barnum rule . . . a noise trader is born every minute."). 
Brokers are paid a commission on every stock transaction they execute, profiting from trades regardless of whether the trading investor profits. They therefore have financial incentives to encourage trading. ${ }^{80}$ One way brokers can persuade investors to trade is by providing them (either knowingly or unknowingly) with imperfect information that suggests that a particular stock or industry sector is significantly underpriced and creates perceived opportunities for speculative profits.

The brokerage industry has developed a variety of ineans of imparting such biased and limited information to investors, from the crude tactics of boiler rooms, cold calls, and outright misrepresentations, ${ }^{81}$ to the more subtle methods of "full service" houses that purport to advise investors on favorable trades. ${ }^{82}$ Federal law prohibits brokers (like other persons) from using fraud in the sale of securities. ${ }^{83}$ It is extremely difficult, however, to prove that slanted advice was fraudulent, both because of the evidentiary problems involved in proving scienter ${ }^{84}$ and the content of brokers' often-verbal representations, and because the very nature of stock

80 See generally Nancy B. Kurland, The Ethical Implications of the Straight-Commission Compensation System-An Agency Perspective, 10 J. Bus. Ethics 757 (1991) (noting that the commissiou system creates "blatant conflicts of interest" that invite brokers to encourage trades without regard to clients' needs).

81 See generally Thomas L. Hazen, The Law of Securities Regulation $\S 10.8$, at 429-30 (2d ed. 1990) (describing high pressure sales tactics sucls as boiler rooms and cold calls).

82 Langevoort, supra note 6 , at 752 (describing the services provided by full service brokers); see also Tom Herman, Not All Discount Brokers Offer the Same Bargains, Wall St. J., Mar. 6, 1991 at C1 (comparing full-service firms with discount brokers that do not advise but only execute trades and estimating that discounters handle $20 \%$ of imdividual investors' trades).

Another way to encourage trading is to couvince the client not of the inerits of a stock, but of the inerits of the broker. The client inay be persuaded to trade when and what the broker advises, or to give the broker discretionary autliority to trade ou the client's behalf. Once granted authority, the broker can turn over the imvestor's account as often as six times annually before discretionary trading is regarded as excessive "churning." See Hazen, supra note $81, \S 10.10$, at 436 .

83 See, e.g., 17 C.F.R. $\$ 240.10 b-5$ (1994) (prohibiting persons froin using fraud or misrepresentation in connection with the purchase or sale of securities).

84 Apart from the usual evidentiary problems associated with proving state of mind, scienter may be difficult to prove because adverse selection ensures that inany brokers who give biased advice are sincere. The nodest individual who doubts her own stock-picking ability is unlikely to thrive in the commission-based brokerage profession. Only those who honestly believe they can identify and recommend mispriced securities (or are willing to inake that representation dishonestly) are likely to survive in the industry. Thus, the broker who advises a chent that a particular stock is a "steal" may be fraudulently trying to 
analysis requires observers to consider only a fraction of the vast array of information relevant to stock values. ${ }^{85}$ The rational investor who falls prey to an unscrupulous or overoptimistic broker (and to judge from reported cases, many do) eventually comes to distrust the broker's advice and stops trading with that broker. In the ineantime, however, she may have suffered substantial losses froin bad trades and brokerage commissions. Once bitten, twice shy; but still once bitten.

\section{The Role of Institutional Investment Funds}

A second common financial intermediary that may promote $\mathrm{HE}$ trading is the institutional investment fund. Although over 50 milhon individuals in the Uinited States own stock directly, ${ }^{86}$ inany more own stock indirectly, through inutual funds, pension funds, insurance companies, and the like. Such institutional arrangements sever the individual investor from the trading decision. Trading occurs only at the institutional inanager's behest.

Institutional stock ownership has grown steadily over the past few decades, with U.S. institutions' share of outstanding corporate equity mcreasing froin approximately six percent in 1950 to fortytwo percent in 1992.87 At first glance, institutions' increasing role in securities markets might appear to offer hope of reducing the incidence of $\mathrm{HE}$ trading. In theory, institutional entities have potentially infinite lifespans, suggesting that they are not subject to the same demographic influences that lead successive generations of natural persons mistakenly to try their hands at speculative trading. Thus evolutionary pressures might eventually lead imstitutions to abandon HE-based trading strategies.

But while institutional entities have theoretically infinite lifespans and memories, their human agents do not. The investor who

foment trading, but sle may simply be an optimist who believes sle lias a knack for picking underpriced stocks.

85 Financial intermediaries who advise investors necessarily provide them with only a limited subset of the virtually infinite information relevant to stock valuation. Moreover, brokers who advise clients are only required to have an "adequate basis" for their recommendations. See Hazen, supra note 81 , $\$ 10.6$, at 423 .

86 New York Stock Exchange, supra note 31, at 85.

87 Id. at 89 . By 1992, private and government pension funds and mutual funds alone held a total of $\$ 1.846$ trillion in stocks, $33 \%$ of the $\$ 5.540$ trillion value of the market portfolio. Id. 
relies on a fund manager's trading skills rather than her own is still hoping to profit from what she perceives as her fund manager's superior trading ability. Similarly, a fund manager, like any other individual, begins trading im optimistic ignorance of his own relative abilities, hoping time will prove him to be a canny judge of stocks. ${ }^{88}$ Once again, stock trading's negative-sum nature works remorselessly. Institutional funds that actively manage their portfolios by trying to identify and to trade mispriced stocks on average do worse than the market. ${ }^{89}$ When a fund manager does worse than the market, as most fund managers do, the fund may eventually replace the old manager with a new one, and the learning process will begin anew. ${ }^{90}$ A fund that proves chromically unable to select a winning manager and persistently underperforms the market may lose investors and eventually fail, exiting the trading market just as unsuccessful individual traders do.

But because self-selection ensures that both the average fund manager and the average fund investor believe the fund manager has above-average trading skills, the common practice of institutional imvesting does not prevent investors from trading in the statistically mistaken belief they can profit by doing so. Indeed, the opportumity to invest through institutional entities may actually

88 The evidence suggests that the practice of institutional investing has not reduced $\mathrm{HE}$ trading. Pension fund and stock mutual fund portfolio turnover rates somewhat exceed the market turnover rate. Compare supra note 31 (noting turnover of over $55 \%$ for all equity holdings) with infra note 163 and accompanying text (noting $75 \%$ turnover rate for stock mutual funds) and Effects of Short-Term Trading on Long-Term Investments: Hearing on S. 1654 and S. 2160 Before the Senate Comm. on Finance, 101st Cong., 2d Sess. 58 tbl. 2 (1990) [hereinafter 1990 Hearing] (noting that turnover ratios of pension funds' equity portfolios varied from $51.9 \%$ to $63.2 \%$ between 1981 and 1986). The vast preponderance of this trading can be traced to active management, whose explicit goal is to beat the market by identifying mispriced stocks. See infra Part II.B.1. In the case of stock equity funds, the penchant for trading persists despite tax rules explicitly designed to discourage short-term trading by mutual funds. See Kiefer, supra note 10, at 2 (noting tax rules that prohibit mutual funds from deriving more than $30 \%$ of their gross income from sales of securities, futures, and options held fewer than three months).

89 Supra note 30 .

90 See Employee Benefit Research Institute, EBRI Issue Brief No. 143, Pension Fund Portfolio Turnover and Performance Evaluation 25 tbl. 13 (1993) [hereinafter EBRI Issue Brief] (noting that average tenure of equity managers at surveyed pension funds varied from 5.7 to 6.3 years between 1986 and 1990); snpra notes 75-77 and accompanying text (noting that more than $85 \%$ of equity mutual funds are headed by managers with less than ten years tenure). 
increase the incidence of $\mathrm{HE}$ trading by giving investors a perceived second, or even third, "bite at the apple."

Consider the following scenario. Mary, a successful professional, has accumulated enough wealth by her thirties that she decides to invest in the stock market. Because she has a high opinion of her own abilities, she first attempts to trade stocks herself. In time she learns that she is losing money trading her own picks and concludes that she is not a good judge of stocks. She then turns to one or inore brokers for advice and endures another round or two of costly trading before concluding that she is no better at picking brokers than she was at picking stocks. In other circumstances, Mary might then decide to avoid further trading costs and fall back on a buy-and-hold strategy. But $\dot{n} 1$ a world where individuals can invest through institutions as well as directly, an investor who is no longer optimistic about her ability to pick stocks or brokers may still remain optimistic about her ability to pick fund managers. Mary may shift her savings through a series of mutual funds, each of which underperforms the market, before concluding that she is no better at picking fund managers than she was at picking stocks or brokers. ${ }^{91}$

As this example illustrates, nicreasing the variety of financial intermediaries through which nivestors can trade increases the number and types of overoptimistic mistakes investors can nuake. ${ }^{92}$ In a world without financial intermediaries, the nivestor who attempts to make money by speculating in stocks may need years to discover her relative trading ability (after all, given stocks' natural volatility, how can the unfortunate trader who loses in a particular year conclude with certainty whether she was the victim of overconfidence or simple bad luck?). In a world where investors can choose to rely not only on their own trading skills but also on the skills of a broker or fund manager, however, lessons that used to take years to learn can take a lifetime. Thus financial intermediaries help perpetuate HE markets.

91 Mary at this point has two options: exit the market or switch to a bny-and-hold strategy, perhaps by investing in an index fund. See infra notes 152-56 (discussing index funds).

92 The same risk may be posed by increasing the variety of investunent vehicles available to investors. Mary inay lose inoney first by trading stocks, then bonds, then stock futures, and so forth. See infra notes 313-35 and accompanying text (discussing derivatives inarkets). 


\section{E. HE Theory and The Relationship Between Stock Prices and Fundamental Values in An "Efficient" Market}

As the above discussion illustrates, the HE model offers a variety of insights into the nature and behavior of the individuals and mstitutions who trade on secondary markets. $\mathrm{HE}$ theory also offers important insights imto the nature of market prices. In particular, the HE model has significant and controversial implications for the relationship between a stock's market price and the best estimate of its intrinsic economic value.

\section{The Rise (and Fall?) of Conventional Efficient Markets Theory}

One of the most influential concepts in modern financial theory is the Efficient Capital Markets Hypothesis ("ECMH"). According to the ECMH, in an "efficient" market, stock prices respond so quickly to new information relevant to value that it is impossible for investors to earn short-run profits by buying on good news or selling on bad news. ${ }^{93}$ Thus, the General Motors shareholder who hopes to avoid a loss by selling her GM shares after the company annormces an unexpected decline in earnings will find that by the tine she calls her broker, it is too late; GM's price has already dropped. Substantial empirical evidence confirms that most stock prices are efficient in this "informational" sense. ${ }^{94}$

93 See generally supra note 13 (discussing the ECMH and listing sources).

94 Enpirical tests of informational efficiency generally fall into three categories. "Weak form" tests examine whether market prices reflect all information contained in past price movements. Studies confirm the market is weak form efficient; it is impossible (for academics, at least) to predict profitably future movements in stock prices froin past price clranges. Brealey \& Myers, supra note 13, at 287; Elton \& Gruber, supra note 13, at 40318. "Semistrong form" tests examine whether prices reflect all public information, such as earnings announcements or newspaper reports. The evidence suggests that prices respond efficiently to a wide variety of public information. Brealey \& Myers, supra note 13, at 287; Elton \& Gruber, supra note 13, at 418-25. "Strong form" tests examine whether all public and nonpublic information is incorporated into stock prices. Although strong form tests are difficult to devise because researchers do not, by definition, have access to nonpublic information, some have tried to test strong form efficiency by determining whether traders who are likely to have access to nonpublic information earn better-than-average trading returns. The results are mixed; corporate management and exchange specialists show superior returns, whereas mutual funds do not. Brealey \& Myers, supra note 13, at 287; Elton \& Gruber, supra note 13, at 425-27; Gilson \& Kraakman, supra note 13, at 555-56. But see generally Williain K.S. Wang, Some Arguments that the Stock Market Is Not 
Commentators frequently go on to assert, however, that efficient prices are accurate prices. In other words, stock markets not only respond to new information quickly, but also respond correctly, so that market prices accurately reflect best estimates of expected risks and returns. ${ }^{95}$ This stronger interpretation of market efficiency, which securities scholars often label "fundamental value efficiency,"96 rehes not only on the ECMH but also on the Capital Asset Pricing Model ("CAPM"). ${ }^{97}$ The ECMH predicts that market prices respond quickly to new information but says nothing about the quality or rationality of the information itself. General Motors stock may fall quickly after GM announces a decline in earnings; it may also drop quickly after a popular astrologer gives the firm an unfavorable horoscope reading. The CAPM, however, predicts that rational mvestors measure stock values solely in terms of their likely economic returns and their nondiversifiable (or "beta") risk, ${ }^{98}$ and that beta risk and return are positively and hn-

Efficient, 19 U.C. Davis L. Rev. 341, $349-59$ (1986) (citing studies suggesting markets are not perfectly informationally efficient).

The fact that stock prices are efficient according to the weak, semi-strong, or strong tests does not prove that these prices reflect intrinsic or fundamental values. See infra note 134; see generally Bruce N. Lehmann, Asset Pricing and Intrinsic Values: A Review Essay, $28 \mathrm{~J}$. Monetary Econ. 485, 491 (1991) ("[U]npredictability of returns is necessary for market efficiency but is not a sufficient condition for price to equal objective intrinsic values.").

95 See Langevoort, Market Efficiency, supra note 27, at 856 (noting that according to much efficient market literature, prices reflect a rational estimate of value); Summers \& Summers, supra note 8 , at 264 ("[T] he efficient markets view that stock prices will always reflect fundamental values has, until recently, commanded widespread allegiance from academic students of financial markets.").

$96 \mathrm{See}$, e.g., Wang, supra note 94 , at $344-49$ (distinguishing "information-arbitrage" efficiency and "fundamental-valuation" efficiency); see also Kiefer, supra note 6, at 888-89 (contrasting fundamental value and informational efficiency).

97 See Gordon \& Kornhauser, supra note 13, at 765 (noting that the argument that an efficient market produces accurate prices rehes on CAPM as model underlying tests of ECMH); Stout, supra note 11, at 1241-42 (noting that claims of fundamental value efficiency require CAPM as well as ECMH). See generally Brealey \& Myers, supra note 13, at 136-65 (explaining the Capital Asset Pricing Model).

98 Modern portfolio theory predicts that imvestors valuing financial instruments are concerned only with the expected returns from sucl imstruments, and the expected risk (variation) in those returns. Investors prefer a low-risk investunent to a high-risk mvestunent with the same expected return, and so deinand a premium in the form of greater expected return to bear risk. Moreover, because much risk can be eliminated by holding a diversified portfoho of many stocks whose "alpha," or firm-specific, risks counteract, diversified mvestors care only about nondiversifiable market, or "beta," risk. See generally Brealey \& Myers, supra note 13, at 125-65 (explaiming the concepts of CAPM and nondiversifiable risk). 
early correlated. ${ }^{99}$ Taken together, the ECMH and CAPM predict that efficient markets will quickly and correctly digest all information relevant to economic risks and returns, producing prices equivalent to best rational estimates of stocks' fundamental economic values. ${ }^{100}$

During the 1970s and 1980s, the notion that informational efficiency necessarily imphies fundamental value efficiency, and that stock inarket prices consequently provide accurate estimates of stocks' fundamental values, enjoyed great popularity in the legal culture. ${ }^{101}$ Fundamental market efficiency was described as "an article of doctrinal faith in corporate and securities law"102 that scholars and regulators "rush[ed] to embrace and apply."103 The belief that stock markets accurately price securities influenced the decisions of judges, legislators, and the SEC.104

Yet even as the legal culture enthusiastically adopted the notion of fundamental value efficiency, financial theorists voiced increasing skepticism. ${ }^{105}$ Empirical studies identified a host of market

99 The CAPM predicts that beta risk and return bear a direct and linear relationship, because in an efficient market investors can replicate the risks and returns of a high-beta or low-beta portfolio by holding the market portfolio and either lending at the risk-free rate or borrowing at the risk-free rate and using the borrowed funds to buy more stocks. Id. at 136-39.

100 Thus the adage, "[T]rust market prices." Id. at 290.

101 See, e.g., Gilson \& Kraakman, supra note 13, at 550 ("[T]lue ECMH is now the context in which serious discussion of the regulation of financial markets takes place."); Gordon \& Kornhauser, supra note 13, at 764 (noting "legal rush to embrace and apply" efficient market theory); Langevoort, Market Efficiency, supra note 27, at 851 (explaining efficient market theory "lias a strong presence in the contemporary culture of securities regulation"); Stout, supra note 23, at 621 (recognizing that market efficiency has "captured the hearts and minds of the securities culture").

102 Langevoort, Market Efficiency, supra note 27, at 872.

103 Gordon \& Kornhauser, supra note 13, at 764.

104 See Marcel Kahan, Securities Laws and the Social Costs of "Inaccurate" Stock Prices, 41 Duke L.J. 977, 982-87 (1992) (surveying doctrines designed to increase markets' ability to produce accurate prices); Stout, supra note 11, at 1258-96 (describing how belief that market prices reflect values las influenced policy); Stout, supra note 23, at 637-40 (describing how the desire to improve efficiency lias influenced policy). But see Langevoort, Market Efficiency, supra note 27, at 851-52, 900 (acknowledging the general acceptance of the efficient market lypothesis, but suggesting that regulators may cite market efficiency as a rationalization for policies they would adopt in any case).

105 As Professor Langevoort puts it, a "gulf . . . developed between the current economics literature and the persistent, seemingly static, conception of inarket efficiency in the legal culture." Langevoort, Market Efficiency, supra note 27, at 854. See also Gordon 
anomalies ${ }^{106}$ _mcluding "small firm effects,"107 "overvolatility" results, ${ }^{108}$ "mean-reversion effects," 109 and "closed-end mutual fund puzzles"110_tliat are impossible to reconcile witl the notion that stock prices reflect best estimates of risks and returns. The rising tide of evidence agamst the CAPM and fundamental value efficiency lias led some economists to conclude tliat orthodox efficient market theory is suffering "a near-death experience." 111 One

\& Kornhauser, supra note 13 , at 765 ("It may be only a slight overstatement to say that only in the legal literature is CAPM considered an accurate account of market processes.").

106 See generally Langevoort, Market Efficiency, supra note 27, at 863-64 (noting that a substantial body of data froin 1970 s and 1980s "appear[s] flatly to contradict" ECMH); Peter Fortune, Stock Market Efficiency: An Autopsy? New Eng. Econ. Rev., Mar.-Apr. 1991, at 17, 34 (noting that empirical evidence "provides an overwhelming case against the efficient inarket hypothesis").

107 Studies lave slown that low-capitalization firms' stock returns liave outpaced average market returns. See William F. Sharpe \& Gordon J. Alexander, Investınents 447 (4th ed. 1990). If markets were efficient, then one should be able to attribute the higher returns of sinall coinparies to higher beta risk. The evidence suggests, lowever, that returns are significantly above what one would expect given sinall firms' betas. See Fortune, supra note 106, at 22 (describing "small-firm effect"); Elton \& Gruber, supra note 13, at 429-30 (citing possible explanations for at least part of sinall firms' excess returns).

HE theory can explain the small firm effect as a consequence of the fact that sinall firms are relatively neglected by the larger pool of investors. See Stout, supra note 11, at 1257 n.112 (explaining sinall firm effect given investor heterogeneity).

108 "Overvolatility" studies have found that stock prices exhibit far more variation over time than is consistent with historic variations in dividends and earnings. See, e.g., Robert J. Shiller, Do Stock Prices Move Too Much to be Justifled by Subsequent Changes in Dividends?, 71 Am. Econ. Rev. 421, $433-34$ (1981).

109 "Mean-reversion" studies lave found that after large upswings or downswings, stock prices tend to revert towards their original level, a plienomenon inconsistent with the ECMH's prediction that prices sliould follow a randoin walk. See, e.g., Werner F.M. De Bondt \& Ricliard Thaler, Does the Stock Market Overreact?, 40 J. Fm. 793, 799 (1985) (discussing "overreaction lyypothesis"); Werner F.M. De Bondt \& Richard H. Thaler, Further Evidence On Investor Overreaction and Stock Market Seasonality, 42 J. Fin. 557, 579 (1987) (saune).

110 The "closed-end mutual fund puzzle" refers to anomalous discounts on closed-end mutual fund shares. The existence of sucl discounts contradicts the ECMH because, if markets were efficient, the discount would be eliminated by bargain-seeking investors' buying into the fund. See Fortune, supra note 106, at 22-23 (discussing puzzle); Wang, supra note 94, at 389-91 (attempting to explam the puzzle and concluding that the market is "not very efficient").

111 Fortune, supra note 106, at 35; see also David Dreinan, An Inefficient Market, Forbes, Mar. 28, 1994, at 146 (claiming tliat efficient inarket theory is "in its death throes"); Lehmann, supra note 94 , at 485 ("It is open season on the efficient markets lyypothesis."). Legal scliolars also liave begun to voice serious doubts about the wisdom of the legal culture's infatuation with fundanental value efficiency. See, e.g., Langevoort, Market Efficiency, supra note 27; Stout, supra uote 11; Wang, supra note 94. 
eminent theorist has gone so far as to describe the efficient market as "the most remarkable error in the history of economic theory." 112

Increasing disillusionment with the concept of fundamental value efficiency has spurred financial theorists to propose alternative models of stock markets that in some cases depart radically from the orthodox ECMH/CAPM. One theory that has captured much attention is the so-called "noise trader" theory. According to the noise trader model, stock markets tend to attract two kinds of traders: rational traders with access to information that allows them to accurately assess stocks' true values and irrational traders who trade on the basis of rumors, whims, and fads (i.e., "noise"). ${ }^{113}$ Noise trader theory hypothesizes that stock markets are not efficient in the fundamental value sense because noise traders distort market prices. ${ }^{114}$

Noise theorists' willingness to abandon the fundamental economic assumption of individual rationality is strong evidence of economists' frustration with the stock markets' stubborn refusal to behave in accordance with the ECMH/CAPM's prediction of fundamental value efficiency. ${ }^{115}$ Yet such desperate measures may be unwarranted. Heterogeneous expectations theory offers a rational choice explanation of how informationally efficient stock markets may be demonstrably in efficient in the fundamental value sense. ${ }^{116}$

112 Barbara Donnelly, Efficient-Market Theorists Are Puzzled By Recent Gyrations in Stock Market, Wall St. J., Oct. 23, 1987, at 7 (quoting Yale econonrist Robert Shiller). Not surprisingly given its former preeminence, orthodox efficient market theory is dying a long and hard death. See, e.g., Kiefer, supra note 6, at 890 (suggesting that new theories of inefficiency "are not yet the accepted paradigms in the finance literature" and "[a]t this point ... are probably appropriately regarded as interesting new channels of investigation that have some inplications which are more consistent with observed market behavior than the standard efficient markets model").

113 See supra note 34. But see Brett Trueman, A Theory of Noise Trading in Securities Markets, 43 J. Fin. 83 (1988) (developing a model in which noise trading by institutional managers is a rational means of sending false "signal" that manager has access to private information justifying trading).

114 See, e.g., Black, supra note 34, at 532 (arguing that noise traders distort market prices from fundamental values); De Long et al., Noise Trader Risk, supra note 10, at 705 (same); De Long et al., Losses from Noise Trading, supra note 33, at 681 (same).

115 See Posner, supra note 7, at 3 (describing rationality as a fundamental concept in economic analysis).

116 Some proponents of noise theory have suggested that market anoinalies can be explained without resorting to a presumption of imvestor irrationality by taking account of investors' possibly heterogeneous expectations. See De Long et al., Noise Trader Risk, 


\section{Modifying Conventional Efficient Markets Theory To Account for Heterogeneous Expectations}

In its traditional form, the CAPM presumes that investors share hoinogeneous expectations, making identical estimates of the likely risks and returns of various stocks. ${ }^{117}$ Although unreahistic, ${ }^{118}$ the assumption of imvestor homogeneity was a useful device for the pioneering theorists who developed the CAPM to inodel the relationship between stocks' nondiversifiable risks and their expected returns. ${ }^{119}$ Nor does the homogeneity assumption's falsity detract much froin the CAPM's utility for that purpose. When the CAPM is incorporated imto the ECMH to inake predictions about the relationship between a particular stock's market price and its intrinsic value, however, the assumption of investor homogeneity leads to the false prediction that stock prices reflect best estimates of stock values. ${ }^{120}$ Modifying the ECMH/CAPM model to take account of imvestors' heterogeneous expectations produces a model of stock market pricing that preserves the assumption of investor rationahity while nevertheless explaining how inforinationally efficient stock

supra note 10 , at 735 (noting that although noise theory focuses on irrationality, many of its results "could perhaps be derived using a fully rational model with differentially informed imvestors").

117 See Stout, supra note 11, at 1245 n.52 (citing authorities).

118 The artificiality of the hoinogeneous beliefs assumption was fully recognized by the pioneers who developed the CAPM. See, e.g., William F. Sharpe, Portfolio Theory and Capital Markets 104 (1970) (noting that "[e]ven the most casual empiricism suggests" that investor behefs concerning the values of stocks differ).

119 See Brealey \& Myers, supra note 13, at 137 (explaining that the CAPM was developed to help analyze the relatiouship between degree of risk and expected risk premium).

${ }^{120}$ At least two of the pioueers who developed the CAPM, John Limtner and William Sharpe, clearly recognized that when imvestors have differing expectations and either short sales or investor wealth are limited, efficient market prices no louger bear any necessary relationship to best estimates of value. Lintner concluded that in a market where imvestors make heterogeneous estimations of risks and returns and short sales are restricted, market price will be a weighted aggregate valuation of the optimistic subset of investors who choose to hold stock, investors will hold unique portfohos of those stocks they value most highly, and market price of risk will vary from stock to stock, contrary to predictions of standard CAPM. John Lintner, The Aggregation of Investor's Diverse Judgments and Preferences in Purely Coinpetitive Security Markets, 4 J. Fin. \& Quantitative Analysis 347, 384-97 (1969). In a chapter titled "Disagreement," Sharpe notes that when imvestors' expectations differ, "[t]he market portfolio will seem mefficient to soine, and perhaps to all investors." Sharpe, supra note 118, at 104-13. If short selling or mvestor wealth is limited, Sharpe predicts, "The demise of the capital market line is followed immediately by that of the security market line. The theory is im a shambles." Id. at 112. 
markets can produce prices that fail to reflect best estimates of fundamental value. ${ }^{121}$

HE theory suggests that when investors disagree about future stock performance, they develop personal preferences for, and aversions to, particular stocks. ${ }^{122}$ John thinks General Motors is a bargain at $\$ 100$, whereas Mary thinks GM at $\$ 100$ is a sucker's bet. Shares in a particular firm will tend to be held by the mvestors who are most optimistic about the firm's prospects. ${ }^{123}$ John buys GM; Mary does not.

Taken to its logical extreme, HE theory would seem to predict that all of a firm's shares will end up in the hands of the one imvestor who is most optimistic about the company's prospects. If investors enjoyed infinite wealth and were imdifferent to risk, each corporation's equity might indeed be held by a single investor. ${ }^{124}$ But investors are risk-averse and have limited wealth; their budgets and their tolerance for diversifiable ("alpha") risk curtail their willingness to invest large amounts in a single firm. Once John has invested a sizeable portion of his finite savings in General Motors, he may prefer to buy shares in another firm he perceives as not quite as good a bargam simply to maintain a diversified portfolio. HE theory thus predicts that a firm's shares will be held by an opti-

121 See generally Stout, supra note 11, at 1244-52, 1284-95 (modifying CAPM to account for investor heterogeneity and considering implications for relationship between stock prices and values).

122 See Lintner, supra note 120 , at 397 (explaining that in a market where investors inake heterogeneous estimations and short sales are restricted, investors will not hold market portfolio but unique portfolios of the stocks they value inost); Stout, supra note 11, at 1246 (stating that investors prefer stocks they subjectively perceive as imderpriced and avoid those they subjectively perceive as overpriced).

123 See Lintner, supra note 120 , at 397 (describing market price as a weighted aggregate valuation of that optimistic subset of investors who choose to hold stock); Stout, supra note 11, at 1246 (noting that shares tend to be held by those who attach highest subjective valuation to them). Stocks tend to be held by optiumists because legal and practical restrictions on "short sales" limit the ability of pessimists to take a position in a security. See Stout, supra note 11, at 1248 \& n.68 (discussing short sales restrictions).

124 See Harris \& Raviv, supra note 38, at 481 (suggesting that if short sales were restricted and investors were risk-neutral, each stock would end up being owned entirely by the investor who was inost optimistic); Stout, supra note 11, at 1246 (same).

Modeling investor heterogeneity in a world where mvestors are risk-neutral and short sales are not restricted produces the odd prediction that no stable market price exists. See De Long et al., Noise Trader Risk, supra note 10, at 710 (noting that if investors lield "with certainty different behefs about expected returns[,] they would ... try to take infinite bets against each other... [ [and an] equilibrium would not exist"). 
mistic subset of investors, who may perceive the stock to be "underpriced" yet be unwilling to buy more at inarket price. ${ }^{125}$

Modifying the traditional ECMH/CAPM to account for investor disagreement consequently yields the controversial predictionnevertheless borne out by inuch einpirical evidence, including several recent studies - that investor demand for particular stocks will be downward-sloping. ${ }^{126}$ Even at a very high price, a corporation may sell a modest number of shares to the "superoptimists" who have the highest opinions of the firm's prospects. Lowering the price allows the firm to sell more shares, both because the lower price allows a greater number of investors to perceive the stock as a bargam and because it induces the optimists who already own shares to accept the risk of purchasing a bit more. Market price thus will be set by the intersection between a stock's supply function (fixed in the short run) and the downward-sloping aggregate demand function. Increasing the available supply of stock by issu-

\footnotetext{
125 Stout, supra note 11 , at $1246-47$.
}

126 See Stout, supra note 11, at 1247-58 (arguing that HE theory and empirical evidence both support downward-sloping demand). The claim that deinand for stocks is downwardsloping is controversial because the orthodox ECMH/CAPM predicts that the demand function for stocks should be horizontal or "perfectly elastic." In other words, investors should be willing to buy an infinite amount of a stock at below-market prices and be willing to sell an infinite amount at above-market prices. Id. at 1236-39. The perfect elasticity prediction flows naturally from the CAPM's assumption of investor homogeneity because at below-market prices all investors view a stock as a bargain and wish to buy it, whereas at above-market prices all investors see a stock as overpriced and wish to sell. Id. at 1245 .

Because downward-sloping demand for stocks is inconsistent with orthodox ECMH/ CAPM, for many years the suggestion that stock demand might be downward-sloping was regarded as close to heresy in financial circles. Yet financial economists increasingly have come to accept that, as an empirical matter, imvestor demand for imdividual stocks is indeed significantly downward-sloping and that investors' heterogeneous expectations may explain that observation. See id. at $1245 \mathrm{n} .56,1252-58$ (citing authorities and studies); Gordon B. Pye, Does the Market Always Know Best?, Fm. Analysts J., July-Aug. 1989, at 4,5 (concluding that there is "ample" empirical evidence that the demand curve for shares "may have considerable slope"). Recent studies include Robert W. Holthausen, Richard W. Leftwich \& David Mayers, Large-Block Transactions, the Speed of Response, and Temporary and Permanent Stock-Price Effects, 26 J. Fin. Econ. 71, 73-74, 90 (1990) (noting that if demand for stocks is sloping, large trades will cause permanent price changes directly correlated with size of trade, and finding "strong evidence of a permanent price effect that increases with block size"); Claudio Loderer, John Cooney \& Leonard D. Van Drunen, The Price Elasticity of Demand for Common Stock, 46 J. Fin. 621, 621-22, 648-49 (1991) (presenting study results consistent with melastic demand); cf. Bagwell, supra note 53 (discussing upward-sloping supply curves in the context of Dutch auction stock repurchases). 
ing more shares will lower market price, whereas contracting supply (for instance, through a corporate repurchase program) will raise market price. ${ }^{127}$

The possibility that investor demand for stocks is downwardsloping carries important implications for the relationship between a stock's market price and its intrinsic value. According to the

127

Figure 4:

Equilibrium Market Price with Downward-Sloping Demand

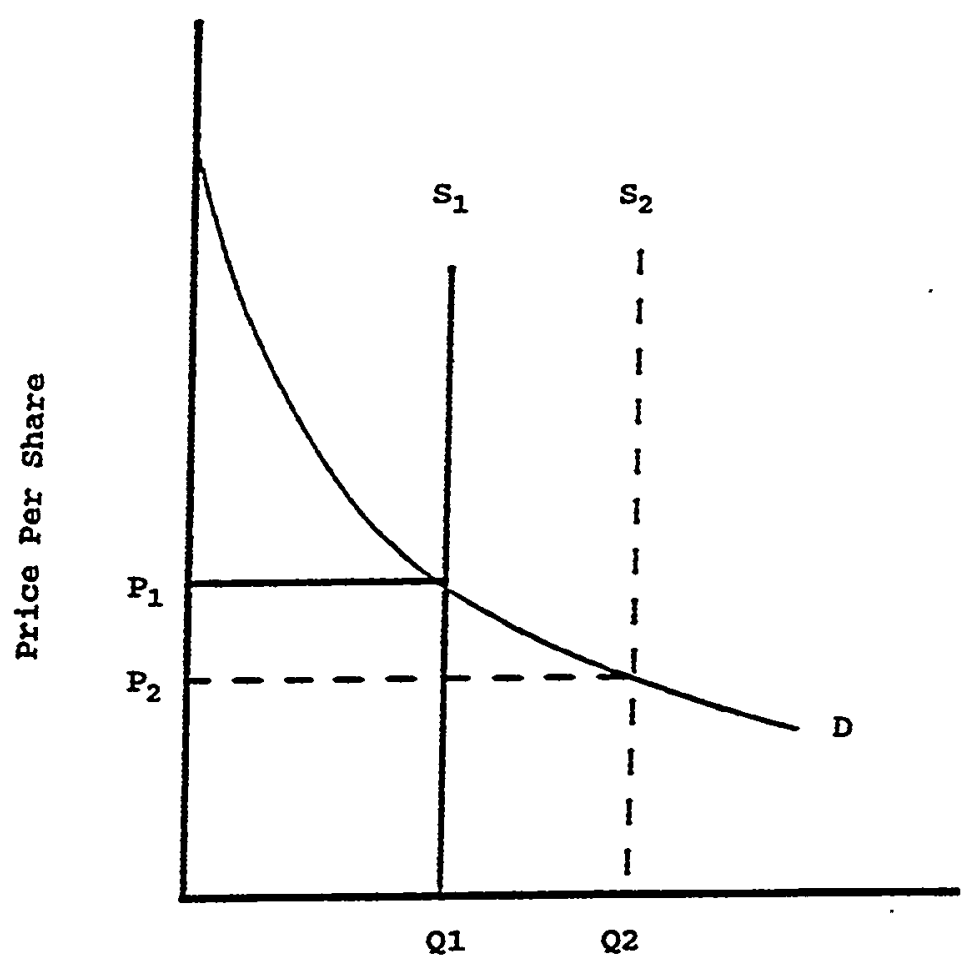

Quantity of Shares Demanded

Figure 4 illustrates how market price is set when aggregate demand for stocks is downward-sloping. The supply of any given stock is fixed, in the short run, as illustrated by vertical supply function $S_{1}$. Given a downward-sloping deinand function (D) for a stock, equilibrium price $P_{1}$ is determined by the interseetion of $D$ and $S_{1}$. If the firm issues more shares and increases the supply of stock to $S_{2}$, equilibriuun price decreases to $P_{2}$. See Stout, supra note 11, at 1249-50 (describing how market price is set under assumption of investor heterogeneity). 
orthodox ECMH/CAPM, prices in an efficient market reflect the best possible estimates of stocks' fundamental values. ${ }^{128}$ Under the heterogeneous expectations version of the ECMH/CAPM, however, market price is simply the price at which the least optimistic meinber of the optimistic subset of investors who hold a particular stock would willingly part with some of her shares. ${ }^{129}$ In other words, market price is nothing more than the subjective valuation of the marginal investor. Because there is no reason to presume that the marginal imvestor's valuation is also the best, or most optimal, valuation, ${ }^{130}$ modifying the ECMH/CAPM to allow for investors' heterogeneous expectations destroys any close relationship between a stock's market price and best estimates of its fundamental value. ${ }^{131}$

Prices set in a market of investors with heterogeneous expectations inay still be informationally efficient. Prices may respond quickly to new information either because fresh information changes the marginal investor's estimate of her stock's value or because it entices new imvestors into (or drives old mvestors out of) the market for a particular firm's shares, thus changing the identity of the marginal investor. But even if prices change quickly in response to new information, there is no guarantee they change accurately. Market prices inevitably reflect the aggregate demand of an amalgam of investors with differming opinions, all acting on limited information and most of whoin are mistaken to greater or

128 This simple explanation of fundamental value efficiency is close to a tautology. If investors value stocks only according to their expected risk and returns, and if investors all have identical expectations for stocks, a market price that reflects all available information inevitably refiects that "best," unanimous valuation. A inore sophisticated defense of fundamental value efficiency recognizes that investors' expectations may differ, but argues that over time stocks' prices should come to approximate fundamental values because investors who are poor judges of stocks' intrinsic values lose money and exit the market. The longitudinal HE model suggests that "weeding out" is ineffective in ensuring that prices equal best estimates of value, due to generational effects. See supra Part I.C.2.

129 See Stout, supra note 11, at 1248.

130 In a world of imperfect information, the "best" estimate of a stock's value wonld be the estimate of that investor who has access to, and has considered, all available information rather than just a subset of information.

131 Stout, supra note 11, at 1248-49; see also Lintner, supra note 120, at 384-97, (concluding that when investors make heterogeneous estimations and short sales are restricted, market price of risk varies froin stock to stock, contrary to predictions of standard CAPM); Pye, supra note 126, at 6 (concluding that because investors disagree about stock values, “[t] he market doesn't always know best."). 
lesser degrees. So long as at least a portion of investors in the market are reasonably informed, market prices will not be utterly divorced from reasonable estimates of value. But the connection between price and best estimate of value may be very loose indeed. ${ }^{132}$

The HE model thus offers an answer to a phenomenon that has long puzzled financial theorists: the steadfast refusal of the sophisticated individuals and institutions who participate in securities markets to heed their warnings that "the market knows best."133 The HE model suggests that at least some of the market participants who claim to be able to detect underpriced or overpriced stocks may be correct in their assessments. ${ }^{134}$ Although HE theory predicts that stock traders who expect to profit from trading are inistaken on average, it also, iromically, supports the notion that they may be correct in individual cases. Stock trading may indeed be a game of skill in which the talented and canny inay profit at the expense of their less able fellows. ${ }^{135}$

\section{Are U.S. Stock Markets Heterogeneous EXPECTATIONS MARKETS?}

The HE model of stock trading is logically consistent, its underlying assumptions are plausible, and its predictions accord well with observed market behavior as well as with common perceptions of stock markets. Yet, like any econonnic model, HE theory simplifies a complex reality. In the real world, traders squander

132 As Fischer Black has suggested in the context of noise theory, one "might define an efficient market as one in which price is within a factor of 2 of value, i.e., the price is inore than half of value and less than twice value." Black, supra note 34 , at 533. Although the HE model of stock pricing differs from noise trader theory in several ways-most notably in retaining the assumption of investor rationality, see supra notes 33-34 and accompanying text, and in inodifying rather than rejecting the ECMH/CAPM framework, see supra notes 117-31 and accompanying text-HE theory nevertheless agrees with noise theory's prediction that the market prices of stocks may not reflect their values.

133 See supra note 32 and accompanying text (noting that theorists are puzzled by speculative trading).

134 Einpirical tests of the markets' informational efficiency generally focus on traders' abilities to make profits in the very short run, i.e., hours or days. See authorities cited supra note 94 (discussing tests of efficiency). These tests cannot disprove some investors' abilities to identify mispriced stocks and profit from buying them and holding them for longer periods.

135 But see supra note 71 (discussing possibility that randoin luck explains persistent winners in the market). 
resources trying to beat the market, but they trade for other reasons as well. ${ }^{136}$ Because the pohicy imphications of the HE model depend on determining just how great a role heterogeneous expectations play in the secondary stock markets, this Part examines the available evidence on investors' motives for trading. That evidence suggests that investor disagreenent is indeed the modern markets' raison d'etre.

\section{A. Nonmistaken Reasons for Trading and the Value-Adding Model of Stock Markets}

Investors inay have a number of reasons for trading other than heterogeneous expectations. For example, some portion of the trading observed in secondary markets almost certainly reflects the changing hquidity needs of investors who desire first to put their savings in stocks and then to hquidate their holdings to raise cash for another purpose. Trading driven by hquidity needs would occur even if all investors shared homogeneous expectations. Suppose Jolm and Mary agreed that GM's market price of $\$ 100$ per share exactly reflected its expected future-returns. Jolm would still willingly pay broker commissions to buy, and Mary pay commissions to sell, if thrifty John had accumulated savings under his mattress that he wished to invest, whereas Mary needed to hquidate her holdiugs to purchase a hoine or pay a child's tuition.

Tax concerns also can trigger transactions by investors who perceive stocks to be accurately priced. If Mary bought GM at $\$ 100$ per share and GM's price then dechned to ninety dollars, Mary might sell, not because she predicts GM will declime further, but because selling would allow her to realize a ten dollars per share capital loss that would reduce her tax liability by offsetting otherwise-taxable iucoine. ${ }^{137}$

136 See Harris \& Raviv, supra note 38, at 474 (arguing that explanations for trading "include tax-driven trading, liquidity trading, portfolio rebalancing, and speculation"; speculation "stems, presumably, from disagreements among traders"); Stiglitz, supra note 9 , at 102 (stating that investors trade in order to save or dissave, to change their portfolios, and to beat the market).

137 See generally, Marvin A. Chirelstein, Federal Income Taxation: A Guide to the Leading Cases and Concepts 299 (7th ed. 1994) (discnssing rules for deductibility of capital losses); Josef Lakonishok \& Seymour Smidt, Capital Gain Taxation and Volume of Trading, 41 J. Fin. 951, 953-54 (1986) (describing tax effects of capital losses and limits of tax-induced trading). 
"Portfoho balancing" provides a third reason investors might trade absent disagreement over prices. Modern financial theory counsels investors to maximize their returns given a desired level of risk by holding a diversified portfolio of stocks in combination with some riskless asset, such as government bonds. ${ }^{138}$ Occasionally, the nondiversifiable (beta) risk of the equities portion of an investor's portfoho may shift to the point where the investor must sell off equities and buy bonds (or vise versa) to maintam her desired overall risk level. ${ }^{139}$ Alternatively, a stock might appreciate so greatly that it coines to constitute too large a portion of the investor's portfoho, and she inight sell off some of it to reduce her diversifiable (alpha) risk. ${ }^{140}$ Indexed inutual funds and pension funds that buy and hold the stocks comprising a particular stock index also periodically adjust their portfolios when stocks are listed or delisted from the index. ${ }^{141}$

Because trades motivated by liquidity, tax and portfoho-balancing concerns would occur even if investors enjoyed perfect information and shared homogeneous expectations for stocks' futures, such "nonmistaken" trades, in addition to appearing inutually beneficial ex ante, can, in fact, be inutually beneficial ex post. ${ }^{142}$ This observation suggests an alternative model of stock trading-call it the "value-adding" model - that carries very different implications for the behavior and the social value of stock markets than those of the HE model. In the econormist's parlance, nonmistaken, mutually beneficial stock trades "add value" because investors who pay trading costs to purchase liquidity, tax benefits, or a balanced port-

138 See supra notes $98-100$ and accompanying text; supra text accompanying notes 124 25.

139 See supra notes $98-100$ and accompanying text.

140 See supra note 98 and accompanying text.

141 See infra notes 153-56 and accompanying text.

142 Trades motivated by differing needs for liquidity, diversification, or capital gains or losses reflect differences in investors' tastes rather than in their expectations. Thus, even if two investors sliare identical expectations for the future, one might readily buy stocks that the other sells if the first investor needs to invest the growing pile of cash under her mattress (i.e., has a taste for investing) whereas the second is strapped for casl (i.e., has a taste for hquidity). The transaction costs associated with such trades reduce the two investors' net wealth by transferring some of that wealth to third parties. Because investors who pay for liquidity or diversification receive something they value in return, lowever, such trades still increase net investor welfare. 
folio receive something they value in return. ${ }^{143}$ Under a valueadding model of stock trading, then, trading improves the average trader's welfare, and costs incurred in trading are well spent. ${ }^{144}$

\section{B. The Value-Adding Model versus the HE Model: Some Evidence on Why Investors Trade}

As will be discussed furtler in Part III, the HE inodel of a stock market primarily composed of speculators betting against each other according to their differing predictions, and the value-adding model of a market comprised mainly of mvestors trading to satisfy liquidity needs, reap tax benefits, or rebalance their portfolios, ${ }^{145}$ carry very different normative connotations. The HE inodel's relevance for securities policy thus largely depends on determining

143 A fourth possible form of value-adding trading is "recreational" trading. See supra note 33 and accompanying text (discussing possibility that some investors trade not to profit, but because they intrinsically enjoy the process, and concluding that recreational trading is unlikely to account for more than a sinall portion of speculative activity).

144 The value-adding model also raises the possibility that stock unarkets could sustain a small group of professional traders who systematically outperform the narket by trading at favorable prices with investors willing to accept less-advantageous prices to secure hquidity, tax benefits, or balanced portfolios. In effect, investors seeking such benefits "pay" for them by trading with professionals on terms that allow the latter to extract profits.

An equities trading model in which professionals extract profits by trading on favorable terms with nonprofessionals resembles the classic paradigm of futures markets, which are often described as comprised of risk-averse "hedgers" who do business with risk-neutral "speculators" on terms that allow the latter to profit. See infra notes 181,183 . This model also bears some resemblance to an efficient markets model proposed by Professors Sanford Grossman and Joseph Stightz, who suggest that markets are comprised of informed and uninformed traders, that the latter systematically profit by buying mispriced securities, and that stock prices differ from best estimates of fundainental values just enough to account for the marginal costs of information. Sanford J. Grossman \& Joseph E. Stiglitz, On the Impossibility of Informationally Efficient Markets, 70 Am. Econ. Rev. 393 (1980).

The professionals who systematically profit from trading under the value-adding model, however, are more accurately described as "dealers" rather than "speculators." Although they purchase stocks primarily for resale, they are hoping to profit not from "speculating" on (forecasting) future price changes but rather from the spread between the bid price at which they offer to purchase and the ask price at which they offer to buy. The spread compensates dealers for the cost of storing an inventory-negligible in the case of securities-and for bearing the risk of price changes in the inventory they hold for resale. Thus, dealers who provide hquidity can extract profits even in a market of homogeneous expectations.

145 Serviced, perhaps, by a modest number of profit-extracting professional dealers. See supra note 144 . 
which model best describes the U.S. secondary markets. As an empirical matter, how much trading in modern stock markets is inspired by investors' statistically futile hopes of profiting from their differing price predictions, and how much by their desires for liquidity, diversified portfohos, or tax advantages? ${ }^{146}$

Although there has been hittle formal study of why investors trade, ${ }^{147}$ discovering investors' subjective motivations for trading is not so difficult a task as it may first appear. The HE model's explanatory power in describing the nature of market participants and the relationship between market prices and best estimates of stocks' fundamental values provides indirect evidence that heterogeneous expectations inspire much trading. More direct evidence of why imvestors trade can be found both in investors' stated descriptions of their trading goals and in the volume and patterns of trading. Both forms of evidence suggest that mvestor disagreement drives the stock markets. ${ }^{148}$

146 See infra notes 299-304 and accompanying text (discussing how optimal regulatory policy depends on whether market is primarily $\mathrm{HE}$ or value-adding).

147 Langevoort, supra note 27, at 920, 896 n.153 ("[W] know surprisingly little about who buys or sells in the stock market (and why).").

148 Popular literature may provide a third, albeit indirect, source of information about why investors trade in stock markets. Tales of the market appear in films, books, inagazines and on television. See, e.g., Wall Street (Twentieth Century Fox Film Corp. 1987) (recounting the rise and fall of a young stockbroker and his mside-trading inentor, the notorious Gordon Gekko); Quicksilver (Columbia Pictures Indus. 1985) (describing the story of a former stock trader who returns to the trading floor, discovers le still has "the touch," and makes enough money to help a friend in need); Micliael Lewis, Liar's Poker: Rising Through the Wreckage on Wall Street (1989) (recounting protagonist's life as Saloinon Brothers broker); Alan Rubenfeld, The Super Traders: Secrets \& Successes of Wall Street's Best \& Brightest (1992) (providing autobiographical anecdotes of successful traders); Thoinas D. Saler, Lies Your Broker Tells You (1989) (describiug the brokerage industry); Toin Wolfe, The Bonfire of the Vanities (1987) (describing the travails of a fictional professional bond trader). These tales of the inarket are not tales of technicians fine-tuning alplias and betas. Rather, they are stories of speculation and uitrigue, luck and guile, profitable prediction and mistaken prognostication, and the thrill of winning counterbalanced by the agony of defeat. In the eyes of popular culture, stock markets are indeed casinos, filled with traders placing enormous bets on the future.

Information gleaned froin popular culture must, of course, be taken with a grain of salt. Still the tale of the canny (or not so canny) trader is such a staple of Wall Street lore that it is difficult to dismiss the idea that art accurately reflects life. If the popular unage of the inarket bears any reseinblance to reality, heterogeneous expectations do indeed provide the foundation on whicl modern stock markets are built. 


\section{The Predominance of Active Institutional Management}

Perhaps the most powerful evidence that investor disagreement fuels inodern stock markets is what investors, particularly institutional investors, say about why they trade. ${ }^{149}$ Institutions such as pension funds and mutual funds own approximately half of all equity and account for half or more of all stock trading. ${ }^{150}$ Because mstitutions disclose their mvestment philosophies and strategies to coinply with federal disclosure requirements ${ }^{151}$ and to inarket their wares to individual investors, funds' exphicit characterizations of their own investment goals offer great insight into motives for trading.

149 Economists geuerally are reluctant to rely on the preferences individuals assert, preferring to infer motive from actual behavior. See David W. Barnes \& Lynn A. Stout, Cases and Materials on Law and Economics 5 (1992) (discussing the theory of revealed prefereuces). In the case of institutional trading, however, there is httle reason to beheve that institutional managers who claim they hope to outperform the market are lying. Selfselection reconciles their optimism with the harsh reality that trading is a loser's game, and lying exposes thein to charges of fraud. But see Trueman, supra note 113, at 83 (offering a noise trading inodel where institutional managers trade to create the appearance for their customers that they have nonpublic information, not because they expect to profit). Moreover, even if institutional managers misstate their trading motives, the quixotic hopes of the individual investors who choose to invest in active fuuds remain the essential impetus for institutional trading. Institutions' statements about why they trade remain highly relevant because individuals who invest in funds surely rely on these statements. Choosing to invest money in an active fund that tries to beat the market through trading, rather than a passive fund with a buy-and-hold strategy, reveals individual investors' preferences for HE trading.

150 See Natioual Ass'n of Securities Dealers, supra note 1, at 36 (stating that institutional block trading accounted for $44.5 \%$ of NASDAQ share volume in 1992); New York Stock Exchange, supra note 31, at 89 (stating that in 1992, U.S. institutions-primarily public and private pension funds, insurance companies, and inutual funds-owned $42 \%$ of inarket value of all U.S. equity); id. at 17 (stating that block trades accounted for $54 \%$ of NYSE share volume in 1993). Soine commentators behieve that institutions account for an even higher proportion of all trading. See, e.g., Lowenstein, supra note 10, at 70 (stating that institutions do $75 \%$ of trading).

151 Mutual funds are subject to the disclosure and antifraud requirements of the Investment Company Act of 1940, 15 U.S.C. $\$ \$ 80 \mathrm{a}-1$ to $80 \mathrm{a}-64$ (1988), and in some cases to the Securities Act of 1933, 15 U.S.C. $\$ \$ 77 a-77 a a(1988)$, and the Securities Exchange Act of 1934,15 U.S.C. $\$ \S 78 a-7811$ (1988). See generally Hazen, supra note $81, \S 17$, at $880-$ 83 (discussing registration and disclosure requirements). Federal law also requires pension plans to disclose some information to employee-investors. See Employee Retireinent Incoine Security Act of 1974 (ERISA), 29 U.S.C. $\S \S 1021-25$ (1988); see also 2 Loss \& Sehgman, supra note 16, at 1031-50 (noting that the SEC views some voluntary contributory pension plans as securities that are subject to federal disclosure requireıneuts). 
Institutional managers generally claim to follow one of two basic investment strategies. ${ }^{152}$ The first, and less common, is "passive" management, or "indexed investing". ${ }^{153}$ Index funds buy and hold portfohos of stocks designed to replicate a particular stock index such as the Standard \& Poor's 500 or Wilshire 5000. ${ }^{154}$ They execute trades ouly when necessary to rebalance portfolios as stocks are listed or delisted from the index or to respond to changing liquidity demands as mdividual investors in the fund invest or withdraw capital. ${ }^{155}$ The typical passive fund turns over only four percent to eighteen percent of its portfolio annually. ${ }^{156}$

152 See Elton \& Gruber, supra note 13, at 704-05 (distinguishing passive and active management); Sharpe \& Alexander, supra note 107, at 720-22 (same).

153 See Market 2000 Report, supra note 6, at II-3 (discussing passive management); Elton \& Gruber, supra note 13, at 705-08 (same).

154 The Standard \& Poor's 500 is a value-weighted index of 500 large, NYSE-listed, "blue-chip" stocks. The Wilshire $\mathbf{5 0 0 0}$ is a broader market index that includes many smaller companies traded on the OTC inarket. See generally Elton \& Gruber, supra note 13 , at $626,706$.

155 Kiefer, supra note 10, at 19 (discussing rebalancing); Market 2000 Report, supra note 6, at II-3.

156 Although comprehensive data on passive funds' turnover rates is liard to come by, average turuover appears to be quite low. For example, a survey of equity funds listed in Morningstar Mutual Funds' "Growth-Incone" category found that five of the 104 funds listed described themselves as passive index funds. See Morningstar, Inc., Morningstar Mutual Funds, Apr. 15, 1994, \& 2 at 1, 390, 392, 405-07. Those five funds (the Schwab 1000, SEI Index S\&P 500, Vanguard Index 500, Vanguard Index Total Stock Market, and Vanguard Index Value) held net assets of $\$ 7.9$ billion and had weighted average four percent portfolio turnover in 1992. Id. (1993 data were used for Vanguard Index Total Stock Market, as 1992 data were not available).

Indexed peusion funds seem to have similarly low turnover rates. See EBRI Issue Brief, supra note 90 , at $17 \mathrm{tbl} .7$, tbl. 8 (calculating that large pension fund that rephicates S\&P 500 Index experienced annual turnover ranging from four percent to eight percent in period from 1986-1990, whereas fund that rephcates sinall-capitalization index experienced $13 \%$ to $16 \%$ turnover). A 1989 survey of 36 pension funds by the Financial Executive Institute ("FEI") found that fund managers asked to estimate turnover in their passive equities accounts estimated that between 1986 and 1989, average turnover varied from $13 \%$ to $24 \%$, with an average of $18 \%$ turnover for the four years. See 1990 Hearings, supra note 88, at 106 (statement of Financial Executives Institute, Committee on Investinent of Employee Benefit Assets). These survey results may overestimate true passive fund trading due to the fact that an increasing number of managers of purportedly "passive" funds actually try to outperform the index through arbitrage strategies involving index futures and options. See Elton \& Gruber, supra note 13, at 707 (noting the rise of such strategies and questioning whether such management is truly passive); New Ways to Play the Indexing Game, Institutional Investor, Nov. 1988, at 93-98; James A. White, Index Funds Start Raising Their Sights, Wall St. J., Oct. 20, 1989, at C1 ("Because index-fund inanagers are no longer satisfied with inerely being average, they developed [active] strategies."). 
The second, and far more popular, strategy is "active" investmg. ${ }^{157}$ Active managers take a position in a particular stock or market "based on a forecast about the future."158 In other words, active managers are self-described HE traders who buy and sell on the basis of their differing predictions for individual stocks, industry sectors, and the market as a whole. ${ }^{159}$ Thus, the prospectus for Vanguard's actively managed Windsor II mutual fund describes the fund's strategy as a search for stocks "undervalued" by the market, ${ }^{160}$ whereas the accompanying sales brochure touts "buy low, sell high" as "the classic formula for success in the stock market."161

Although passive investing is becoming inore common, less than twenty percent of pension funds' equity holdings and as hittle as one percent of stock mutual funds' holdings are indexed. ${ }^{162}$ Active managers therefore control eighty percent or more of all institutional equity holdings. Not surprisingly, active funds also trade far more often than passive funds do; for example, the average active stock mutual fund turns over more than seventy-five percent of its portfoho annually, ${ }^{163}$ and turnover ratios of $200 \%$ or inore are not

157 See infra note 162.

158 Elton \& Gruber, supra note 13, at 708; see also Sharpe \& Alexander, supra note 107, at 721 (noting that active managers believe market misprices stocks); Treynor, supra note 29 , at 35 ("All active investing is motivated by forecasts ....").

159 See Elton \& Gruber, supra note 13, at 708-09 (distinguishing three basic types of active managers: (1) "market timers" who switch between equity and debt depending on their forecasts for interest rates and the stock market as a whole, (2) "sector selectors" who move investments between broad classifications of stocks such as industrials and utilities according to their predictions for each sector's economic health, and (3) "security selectors" who search for individual stocks that have been "undervalued" by the inarket).

160 The Vanguard Group of Inv. Cos., Windsor II Prospectus 4 (1994).

161 The Vanguard Group of Inv. Cos., Vanguard Windsor II: For Long-Term Growth Of Capital And Incoine Using A Time-Tested, Value-Based Investunent Approach 1 (1994).

162 See Kiefer, supra note 10 , at 8 (stating that $38 \%$ of pension funds index soine portion of their holdings and that these funds account for $20 \%$ of total pension fund equity holdings); Market 2000 Report, supra note 6, at II-2 to II-3 (stating that in 1992 only $18.3 \%$ of assets in the top 200 pension funds were indexed, whereas "overwhelming majority" of equity mutual fund assets remained actively managed); Vanguard Index Trust, supra note 30 , at 4 (estimating that less than one percent of equity mutual fund assets are held by passive index funds). Again, these figures may shightly overstate the use of indexing, as many so-called passive funds have begun to adopt "innovations" that amount to active (i.e., forecast-based) investunent strategies. See supra note 156.

163 Morningstar, Inc., Morningstar Mutual Funds, Apr. 15, 1994, § 1, at 7 (stating that average equity mutual fund turns over $75 \%$ of portfolio annually). Pension funds experience similar turnover rates. See 1990 Hearing, supra note 88, at 58 tbl. 2 (stating that 
uncommon. ${ }^{164}$ Because active management is so much more common than indexing and because active funds trade so much more frequently, active funds' trades account for the overwhelmingly majority (more than minety percent) of all mstitutional trades. ${ }^{165}$ Investors' hopes of profiting from their active fund inanagers' supposed ability to "buy low and sell high" thus underhe the vast preponderance of all institutional trading. ${ }^{166}$

As noted earlier, the negative-sum nature of the stock trading game works against institutions just as it works against individuals who trade in hope of profit. Active funds incur much higher trading and management costs than passive funds and on average earn lower returns than either passive funds or the inarket as a whole. ${ }^{167}$ Active management's continued popularity in the face of such a poor track record is cogent evidence of self-selection's power to create a market of optimistic losers. ${ }^{168}$

pension funds' average equity turnover ratios varied from $52 \%$ to $63 \%$ from 1981 through 1986, the last year for which information was available); Stephen A. Berkowitz \& Dennis E. Logue, The Portfoho Turnover Explosion Explored, J. Portfoho Mgmt., Spring 1987, at 38, 40 tbl. 2 (showing that during the early 1980s, pension funds and mutual funds experienced similar rates of turnover).

164 See Morningstar, Inc., Morningstar Mutual Funds, Apr. 1, 1994, at 6 (noting several funds with turnovers exceeding $500 \%$ ).

165 Assuming conservatively that active funds control $80 \%$ of institutionally held equity, see supra note 162 and accompanying text, and that actively managed funds trade three times as often, see supra notes 156,163 (noting that passive funds' turnover averages $4 \%$ to $18 \%$, whereas active funds experience $60-75 \%$ turnover), active funds account for at least $92 \%$ of all institutional trading.

166 Liquidity needs, portfolio balancing and tax motives are likely to account for only a very small fraction of active funds' trades. Pension funds are tax-exempt institutions, and mutual funds are taxed only indirectly. See Lakonishok \& Smidt, supra note 137, at 953 (discussing why institutions are less likely to trade for tax reasons). Both types of funds generally hold portfolios of hundreds of different stocks and so are unlikely to do much trading to retain diversification. See supra note 98 (discussing diversification). The law of large numbers similarly ensures that large institutions' hquidity needs will be far less than those of individual investors. See infra note 171. Finally, because many stock mutual funds hold only equities, none of those funds' trading can be attributed to any perceived need to maintain a balancc between the proportion of their portfohos invested in equity and the proportion in bonds. Actively managed pension funds may do some portfolio balancing, but a survey of active pension fund managers found those managers regarded only about $20 \%$ of their trading as attributable to portfolio-balancing needs. EBRI Issue Brief, supra note 90 , at 16 chart 6 .

167 See supra note 30.

168 See Elton \& Gruber, supra note 13, at 710 ("Although index funds have outperformed most active managers, most investors who hire active managers believe they 


\section{Trading Volume and Patterns}

Additional evidence that modern stock markets are primarily HE markets can be found in both the volume and the patterns of stock trading. U.S. equities markets generally exhibit far higher turnover than would seem reasonable if investors were tradiug primarily to satisfy liquidity needs or to rebalance their portfolios. ${ }^{169}$ In 1992, the dollar volume of trading in U.S. equities on the exclianges and OTC market amounted to over fifty-five percent of the value of all equity loldings, implying an average investor loolding period of less than twenty-two montlss. ${ }^{170}$ It seeins highly unlikely that mvestors experience such rapid and dramatic clianges in their liquidity needs that they must invest and then sell their entire portfolios every other year or so. ${ }^{171}$ Similarly, neither the proportions of the stocks held in the average diversified portfolio nor the risk levels associated witl those stocks seem likely to shift so rapidly and dramatically that portfolio-balancing investors inust completely liquidate and reconstruct their portfolios every twentytwo months.

Evidence that market turnover greatly exceeds what is necessary for liquidity and portfoho-balancing needs can be found by comparing the trading behavior of investors who buy stocks directly

can spot the inanager who will outperform the index. This belief persists despite the fact that there is very little evideuce that superior performance is predictable.").

169 See Black, supra note 34, at 530-31 (arguiug that if people traded stocks only to respond to clianges in market risk or liquidity needs, they would trade in individual stocks only "rarely"); cf. Stiglitz, supra note 9, at 102 (noting that some investors trade for liquidity or to change portfolios, but most stock trading is notivated by a desire to beat the market).

170 See supra note 31 .

171 Investors tend to accumulate wealth over a lifetime. See Panl A. Samuelson, Economics 759 (9th ed. 1973) (describing life-cycle theory of wealth and income). Their savings are likely liquidated only in response to pressing needs, like buying a liouse, paying for a college education, or retiring. If clianging liquidity needs explain inost individual stock trades, nineteen years seeins a inore reasouable holdiug period than nineteen inonths. Moreover, the law of large numbers suggests that institutional funds need to trade for liquidity and portfolio-balancing reasons far less often than individuals do. Institutions represent ever-clanging pools of individual investors. So long as new investors buy in at roughly the same rate that old investors redeem their interests (or employees contribute to pension funds at the same rate that retirees collect benefits), the fund can ineet individuals' liquidity needs without buying or selling assets. Liquidity buying and selling is only necessary for institutions when large numbers of imdividuals smultaneously eitler put inoney into, or draw money out of, the fund. 
with the trading behavior of investors who purchase shares in stock mutual funds. ${ }^{172}$ Mutual fund investors rely on their fund inanagers' stock-picking skills rather than on their own. Thus, compared to a direct stock purchase or sale, an investor's decision to put money into or withdraw money out of a stock mutual fund is more likely to reflect her changing hquidity needs or a desire to alter the balance of stocks and bonds in lier portfolio, and less likely to reflect a perception that stocks are underpriced or overpriced. Not surprisingly, turnover in inutual fund sliares is far lower than turnover im individual equities. In 1992, imvestors turned over only twenty-six percent of the value of their lioldings in equity mutual funds. ${ }^{173}$ But even a twenty-six percent turnover rate significantly overstates the level of trading necessary to satisfy imdividuals' liquidity and portfolio-balancing needs, because a good portion of fund redemptions are by investors who have become dissatisfied witl their original fund's performance and wisl to remvest im another fund. ${ }^{174}$ Sucl trading is $\mathrm{HE}$ trading motivated by fund investors' desires to find the superior manager who can beat the market. That inutual funds' twenty-six percent annual turnover probably substantially exceeds wliat is necessary to satisfy individuals' liquidity and portfoho-balancing needs evinces that the fiftyfive percent turnover found in the stock markets inust be driven primarily by otlier motives.

The patterns of trading observed in stock markets also suggest that tax-motivated sales account for only a small portion of stock trades. If most imvestors sold stocks primarily to realize taxable gains or losses, trading sliould exhibit distinctive seasonal patterns. In particular, trading volume should mcrease substantially im December, when investors know with certainty what tax benefits

172 Cf. Black, supra note 34 , at 530-31 (stating that if people traded stocks only to respond to changes in market risk or liquidity needs, they would have hittle reason to trade in individual stocks and would instead trade in mutual funds, index derivatives, or inoney market funds).

173 In 1991, when equity inutual funds held $\$ 368$ billion in assets, mvestors bought $\$ 97$ billion and sold $\$ 54$ billion in equity fund shares. 1993 Statistical Abstract, supra note 2, at $525 \mathrm{tbl}$. 838. Dividing the total market value of equity mutual funds by the larger of either purchases or sales imphies annual turnover of $26 \%$.

174 For example, one survey of investors selling mutual fund shares found that $75 \%$ of those who sold their entire interest, and $36 \%$ of those who sold part of their interest, remvested some or all of the proceeds in another mutual fund. See Investment Company Institute, 1993 Mutual Fund Fact Book 86-88 (1994). 
selling will bring. ${ }^{175}$ Yet empirical studies show December trading volume on the NYSE varies little from normal volume. ${ }^{176}$ Researchers accordingly have concluded that although tax mcentives have some effect on trading, "non-tax-related motives [are] predominant." 177

In sum, the volume and patterns of trading found im modern secondary markets offer significant indirect evidence of imvestors' motivations for trading. That evidence mdicates that trades driven by investors' desires to ineet changing hiquidity needs, minimize tax burdens, or maintain diversified and properly balanced portfolios account for only a minority of all stock trades and that disagreement over the future drives the majority of all transactions. If investors shared loinogeneous expectations, trading volumes in stock markets would be a fraction of what they are today.

\section{The Policy Implications of the Heterogeneous Expectations Model for Federal Securities}

\section{REgULATION}

Part I introduced the HE model of stock trading and explored soine of its implications for the nature and behavior of both stock markets and the investors who participate in them. Part II reviewed the substantial evidence supporting the view that most stock trading is motivated by investors' optimistic lopes of earning above-market returns through speculative strategies. The primary focus of Parts I and $I$, then, has been the HE model's positive aspect, that is, the model's promise in helping observers understand and describe stock traders and stock inarkets.

This Part explores the nornative consequences of the HE model by examining the social value of stock trading through the lens of HE theory. Modern securities regulation is largely premised on the notion tliat stock trading is an activity of value both to traders

175 See Elton \& Gruber, supra note 13, at 417 (describing the tax consequences of yearend selling); Lakonishok \& Smidt, supra note 137, at 954-56 (suggesting that there should be an increase in trading volume at year-end).

176 Lakonishok \& Smidt, supra note 137, at 958; see also New York Stock Exchange, supra note 31, at 13 (showing that NYSE Deceniber 1993 share volume of 5.8 billion shares, amounting to approximately $104 \%$ of one-twelfth of annual volume of 66.9 billion shares).

17 Lakonishok \& Smidt, supra note 137, at 973. 
and to society as a whole. ${ }^{178}$ Federal law declines to interpose itself between investors and their mistakes, opting instead to protect investors through a relatively unintrusive system of antifraud laws combined with rules that require firms to disclose basic information to shareholders and investors. ${ }^{179}$ In short, lawmakers seek to protect and proinote stock trading.

The HE model raises serious questions about the wisdom of such a free-market approach. Although economists celebrate stock inarkets as engines of efficiency and social progress, laymen tend to be inore skeptical, viewing stock inarkets as legalized casinos. ${ }^{180}$ HE theory supports lay misgivings by providing a theoretical foundation for the claim that, in at least two distinct senses, stock trading can be wealth-destructive behavior. High-volume stock inarkets consequently inay reflect a form of market failure that leads to substantial and ongoing social losses rather than efficiency gains.

The social losses associated with $\mathrm{HE}$ trading might possibly be counterbalanced by soine social benefits. In particular, HE trading might contribute to both the liquidity and efficiency (i.e., price accuracy) of modern stock markets. Economic theory counsels, however, that costs and benefits must always be weighed at the margin. A marginal analysis of $\mathrm{HE}$ trading's hquidity and efficiency contributions reveals that these are likely to be minor and significantly outweighed by their costs.

That observation in turn suggests a need to reexamine present federal policy. Although the problem of reducing welfare losses froin HE tradimg is a difficult one, pohicymakers have a number of options short of shutting down inarkets. Part III briefly examines three different possible approaches to reducing the social costs of

178 See supra notes 6-9.

179 See Hazen, supra note 81 , at 7 (noting that the federal system eschews regulating merits of securities on theory that investors are adequately protected by antifraud rules and by the disclosure of information relevant to securities being sold); Hazen, supra note 6 , at 987 (noting that securities regulation based on premises that if imvestors are provided with relevant information, they will make informed decisions and "there is no need to protect a fool from his or her investment folly so long as no fraud . . . is involved").

180 See Irwin Friend, The Economic Consequences of the Stock Market, 62 Am. Econ. Rev. 212, 212 (1972) ("To much of the public, the stock market seems to be a legalized gambling casino. To many economists, the stock market seems endowed with an almost mystical degree of efficiency, even if what is meant by efficiency is not always clear."). 
stock speculation, and explores the advantages and disadvantages of each in the context of the present regulatory scheme.

\section{A. The Social Costs of HE Trading}

The HE model of stock trading is in essence a model of speculation-i.e., trading by rational actors who buy a commodity neither to consume it nor to use it as an mput in solne productive process, but in the hope of profiting by predicting price changes that permit the speculator to resell at a better price. Economists who study speculation usually assume im the tradition of neoclassical economics that speculative trades, like other voluntary exchanges, benefit both the trading parties and society as a whole. ${ }^{181}$ Debate over the possible social costs of speculation therefore has focused on whether speculators can destabilize prices. ${ }^{182}$ The HE model offers

181 Although lay commentators often condemn speculation, economists generally are enthusiastic about speculative trading, believing it improves the welfare of the trading parties and promotes accurate prices. Compare Posner, supra note 7, at 47-48 (stating that speculation "performs a valuable economic function" by helping prices accurately reflect conditions and allowing mutually beneficial trades betweeu speculators and "hedging" consumers) witl Hazen, supra note 6, at 994 (noting history of "inoral disdain" for speculation). Speculative futures markets in commodities, for example, are believed to allow mutually beneficial exchanges between risk-averse consumers who want to hedge against price clianges and speculators who are happy to bear that risk in return for trading profits, thus contributing to more accurate commodities prices. See, e.g., Jean-Pierre Danthine, Information, Futures Prices, and Stabilizing Speculation, 17 J. Econ. Theory 79, 93 (1978) (stating that futures markets may serve insurance function by allowing more riskaverse hedgers to reallocate risks to more risk-neutral speculators and that speculation also las "positive infinence" by transmitting information to prices); Sanford J. Grossman, The Existence of Futures Markets, Noisy Rational Expectations and Informational Externalities, 44 Rev. Econ. Stud. 431, 447 (1977) (noting that in addition to any imsurance benefits futures markets provide, speculation in such markets improves accuracy im prices with attendant social gains).

$\mathrm{HE}$ theory offers an alternative interpretation of speculation by suggesting that under some conditions-for example, the conditions prevailing in modern equities markets-the supposed economic benefits of speculation are illusory, becanse speculative trades are neither mutually beneficial nor likely to improve the accuracy of prices. See snpra notes 29-30 and accompanying text (describing why HE trades do not on average benefit trading parties); infra notes 214-19 and accompanying text (describing why HE trading may distort market prices through false substitution and valuation effects).

182 See, e.g., Baumol, snpra note 29, at 264 (describing low speculation can be seen as destabilizing); Danthine, supra note 181, at 80 (proposing model in whicl speculators stabilize prices); Hart \& Kreps, supra note 12, at 928-29 (describing model in which rational speculation increases price volatility); Stein, supra note 41, at 1124 (concluding that regulators fear speculation is destabilizing, whereas economists teud to believe it has stabilizing influence). See generally Repetti, supra note 12, at 602-03 (noting that 
new insight into the theory of speculation by suggesting two other significant negative consequences of speculation. First, speculation inay lead to social welfare losses when speculators devote valuable resources to transactions that do not, on average, improve their welfare. Second, the hope of speculative profits may create false substitution and false valuation effects that distort market prices and create the risk of allocative inefficiency.

\section{Welfare Losses Resulting From HE Traders' Mistaken Investment in Active Portfolio Management}

Speculative trading can lead to welfare losses because speculation can be enormously costly to speculators themselves. ${ }^{183}$ Inves-

speculation is suspect as coutributing to price volatility and that economic hiterature has focused on that alleged harm). Milton Friedman set the tone for the debate when he argued in defense of currency speculation that "[p]eople who argue that speculation is generally destabilizing seldoin realize that this is largely equivalent to saying that speculators lose money, since speculation can be destabilizing in general ouly if speculators on average sell when the currency is low in price and buy when it is high." Milton Friedman, Essays in Positive Economics 175 (1953). The HE model offers an imteresting insight into the debate by predicting that speculators may indeed lose money. See supra notes $37-43$ and accompanying text (discussing how stock traders can rationally play a negative-sum game).

183 At least two factors may explain the economic hiterature's general failure to recognize the cost of speculation to speculators. First, economists who model speculative trading (whether in stock markets or elsewhere) tend to assume there are no transaction costs associated with trading. See, e.g., Grossman, supra note 181, at 447 (considering normative value of speculative futures while noting that their analysis ignores transaction costs). Second, the speculation literature has tended to ignore the role of heterogeneous expectations in fostering speculation, often by assuming that speculators systematically profit from assuming risks that other market participants (generally known as hedgers) pay them to assume. Stein, supra note 41 , at 1125 (noting that speculation hiterature tends "to ignore the issue of heterogeneous infornation among market participants"); see also Baumol, supra note 29 , at 264 (noting that traditional economic analysis of profitable speculation neglects possibility that skillful speculators are simply profiting at expense of others). Theorists who do allow for investor heterogeneity rarely recognize the full normative implications. See, e.g., Danthine, supra note 181, at 93 (suggesting that if futures markets develop because speculators have differing behefs, these markets exercise "positive influence" by transmitting more infornation to prices); Grossman, supra note 181 , at 447 (adopting model of futures markets in which futures markets develop because traders have differing behefs about future, while noting that such markets produce social gaims by providing "insurance" and price accuracy).

A notable exception can be found in Professor Hirshleifer's work, which clearly recognizes the possibility of social losses from speculative trading. See generally Hirshleifer, Value of Infonnation, supra note 43 (developing model in which heterogeneous expectations leads to social losses as speculators trade with each other); Hirshleifer, supra note 12, at 240, 255, 288 (discussing and rejecting "insurance" model of 
tors who buy and sell in stocks in the statistically mistaken belief that they can beat the market pay a hefty price for their optimism. The most obvious expense associated witl stock trading is broker commissions. ${ }^{184}$ Investors paid over $\$ 16$ billion in broker commissions in 1992 alone. ${ }^{185}$

Yet broker commissions account for just a part-and not even the largest part-of the costs of HE trading. Investors who try to beat the market mcur a number of more hidden costs as well. For example, investors who trade im the OTC market generally must trade with dealers who act as principals to a trade by selling out of, or adding to, their inventory of a particular stock. ${ }^{186}$ Specialists play a similar role on the exchanges, where they do business with custoiners whose buy and sell orders cannot be matclied against another customer's. ${ }^{187}$ Dealers and specialists make a living by profiting from the spread between the "bid" price at which they offer to buy and the higher "ask" price they demand from investors wishing to buy out of their inventory. Spreads are more difficult to detect than commissions because they are implicit in the price an imvestor pays for a stock. ${ }^{188}$ Still, spreads are every bit as inucl a cost of trading. ${ }^{189}$

speculation in which speculators are less risk-averse than hedgers and suggesting that there is more support for model in which speculators trade with other speculators due to differing beliefs).

184 Brokers act as investors' agents by executing buy and sell orders either on an exchange such as the NYSE or with a professioual dealer on the OTC market. See Robert A. Haugen, Modern Investinent Theory 27, 31 (3d ed. 1993) (describing brokerage process).

185 That figure includes commissions on corporate bonds. See SEC, 1993 Annual Report 134 tbl. 12.

186 See Haugen, supra note 184, at 31 (describing OTC trading).

187 See id. at 27 (describing specialists).

188 For example, Morningstar Mutual Funds, a private service that provides extensive infornation on mutual funds' performance and expenses, reports brokers' fees paid by mutual funds in trading but does not attempt to report portfolio value lost to dealer's spreads. See Morningstar, Inc., User's Guide 21 (1994).

189 Another potential trading "cost" from the stock trader's perspective is "market impact cost," the cost of having to make large trades at less-favorable prices because very large sell orders depress market price and large buy orders inflate prices. See Market 2000 Report, supra note 6 , at 22-23 (describing impact costs); Wagner, supra note 30 , at 16 (same). Market impact costs reflect in part a downward-sloping demand function for equities. See supra notes $126-27$ and accompanying text. From a social perspective, because "losses" due to market impact costs benefit one trader at the expense of another, they are wealth transfers rather than net social losses. 
Perhaps the most significant cost associated with speculative trading is the cost of speculators' acquisition and analysis of the information on which they base their differing expectations. Investors trying to predict which stocks or markets will do well invest enormous time and effort gathering and digesting the vast quantities of information relevant to the futures of firms, industries, and the market as a whole. Many investors also pay directly for information and analysis by subscribing to newsletters, consulting research analysts, or hiring professional portfoho inanagers and investment advisors. Although the costs of research and analysis are not, strictly speaking, trading costs, they are a cost of preparing to trade. 190

The admimistrative costs incurred in managing a portfoho of corporate equities are a fourth type of cost associated with stock trading. Even the passive investor who hews to a buy-and-hold strategy must spend some time and effort keeping and updating records of securities owned and transactions executed. But the investor who abandons buy-and-hold and adopts a trading strategy can expect administrative costs to increase with trading.

Any estimate of the aggregate resources investors spend on speculative trading should consider all forms of cost, including commissions, spreads, research and analysis, and portfoho administration. Because individuals rarely have occasion to calculate the value of the time and inoney they spend actively managing their portfolios, comprehensive statistics on the costs of individuals' speculative activities are unavailable. ${ }^{191}$ But pension funds and inutual funds

190 See Langevoort, supra note 6, at 751 ("[T]o make an investment, [one] must incur both search costs (including the cost of gathering information and evaluatimg it) and transaction costs."); Stiglitz, supra note 9, at 109 (noting costs of stock trading include "not only the transactions costs but also much of the costs spent on acquiring infornation, including ... getting the information shigltly earher than it would otherwise become available").

191 One dated but interesting pair of studies examined a sample of individual investors who had maintained accounts over a seven-year period at a brokerage firm. In the first study, individuals held their stocks for a inedian period of between 4 and 6.5 months, earned $9.9 \%$ per annum on portfolios before transaction costs but only $5.5 \%$ after, and in aggregate realized few, if any, excess returns froin trading relative to a passive investinent strategy. See Gary G. Schlarbaum, Wilbur G. Lewellen \& Ronald C. Lease, Realized Returns on Common Stock Investments: The Experience of Individual Investors, $51 \mathrm{~J}$. Bus. 299, 305-07, 321 (1978). In the second study, inedian investors spent between 3 and 5 hours per month inanaging portfolios of $\$ 40,000$ in equities; the average investor in the sample regarded herself, albeit weakly, as "substantially better informed than the average 
keep close track of their business expenses, and equity inutual funds in particular publish extensive information on expenses incurred in trying to beat the inarket. Because equity funds' turnover rates are roughly similar to overall inarket turnover rates, ${ }^{192}$ their expense reports provide a ballpark estimate of investors' aggregate researcli and trading costs.

Morningstar Mutual Funds ${ }^{193}$ reports that equity mutual funds spend an average of $0.31 \%$ of their assets annually on broker coinmissions. ${ }^{194}$ That figure does not include dealer and specialist spreads, which are difficult to detect because they are incorporated into the prices investors pay for securities. ${ }^{195}$ But if spread costs amount to even one-third of commission costs, ${ }^{196}$ investors who buy shares in actively managed stock mutual funds are spendmg more than $0.4 \%$ of the value of their portfolios eacli year on

investor." Lease et al., supra note 67 , at $428,430,431$. Unfortunately, because these studies examined trading behavior at a time when trading costs were much higher and trading volume inuch lower than they are today, their value in explaining modern market behavior is limited.

192 Compare supra note 163 and accoinpanying text (describing average $75 \%$ inutual fund turnover and $52 \%$ to $63 \%$ annual pension fund turnover) with supra note 170 and accompanying text (describing 55\% annual market turnover); see also Kiefer, supra note 10, at 6-7 (reporting turnover rates of pension funds, mutual funds, life insurance coinpanies and NYSE from 1955 through 1987 and concluding institutions' turnover roughly equals inarket's).

193 Morningstar Mutual Funds is a private advisory service that provides a looseleaf service describing the trading philosophies, patterns, and expenses of over 1,000 inutual funds. See, e.g., Morningstar, Inc., Morningstar Mutual Funds, Apr. 15, 1994, (discussing variety of data on funds).

194 Russ Wiles, Funds' Trading Costs Are Low, The Ariz. Republic, Sept. 13, 1993, at E2 (citing Morningstar report that average stock mutual fund pays $0.31 \%$ annually in brokerage commissions).

195 See, e.g., Morningstar, Inc., supra note 188, at 21 (noting that service does uot pubhish information on losses due to dealer spreads, so true trading costs are understated).

196 This highly couservative estimate is based on a recent study that found securities firms' revenues from equities spreads are approximately one-third of their earnings from commissions. See Stoll, supra note 57, at 9 tbl. 1 (noting that in 1990, securities firms reported $\$ 8.555$ billion in commissions and $\$ 2.775$ billion in trading ganis). The estimate is conservative because the study excluded ganis on firms' own investunent accounts from the category "trading gains." Id. at 7. Because gains on investment accounts support the securities industry and coine at the expense of other traders, they may be better categorized as a cost of trading to outside investors. If so, the revenue data suggest that investors lose inore money to spreads than they do to commissions. See New York Stock Exchange, supra note 31, at 92 (noting that in 1992 NYSE-meinber firms reported $\$ 11.6$ billion in revenues from securities commissions and $\$ 16.8$ billion in revenues from all trading and investment gains). 
commissions and spreads. ${ }^{197}$ Moreover, commissions and spreads account for only a minor portion of the costs institutions suffer trying to beat the market. Actively managed mutual funds invest substantial time and effort in researching and analyzing stocks and markets, as well as in admimistering their portfolios. Many funds retain extensive staffs of professional analysts and portfoho managers; others hire outside advisors and managers; some do both. According to Morningstar, stock mutual funds spend an average of $1.42 \%$ of their assets annually on operating, management, and advisory fees and expenses. ${ }^{198}$ That figure excludes (and significantly exceeds) the costs of commissions and spreads. ${ }^{199}$ When commissions and spreads are factored in, it appears that mvestors who buy shares in actively managed stock inutual funds lose more than $1.8 \%$ of their assets eacl year in their quest to outperform the market. ${ }^{200}$

An annual cost of $1.8 \%$ of an investor's portfolio may seem a modest expense. When applied to the entire market portfoho, however, it becomes enormous. The market value of outstanding U.S. equities in 1992 announted to $\$ 5.541$ trillion. ${ }^{201}$ If mutual funds' expenses are typical, investors spent $\$ 100$ billion on stock

197 Investors in the aggregate probably lose more to commissions and spreads than do mutual funds. A recent study of securities firm revenues concluded that investors in the aggregate lost at least $0.5 \%$ of the value of the market portfoho to commissions and spreads between 1980 and 1990 . See Stoll, supra note 57, at 7, 10 (describing annual $0.5 \%$ loss based on securities firm revenues and noting that estimate conservatively excludes firm profits from trading on investment accounts)

198 Morningstar, Inc., 22 Morningstar Mutual Funds, Apr. 15, 1994, at 7 (noting 1.42\% expense ratio).

199 See Morningstar, Inc., supra note 188, at 27 (noting that expense ratios refiect percentage of assets annually lost to operating expenses, management fees, and administrative fees, but do not include losses from commissions and spreads).

200 See The Vanguard Group of Inv. Cos., Plain Talk About Index Investing 2 (1994) (estimating that the average equity fund has an expense ratio of $1.3 \%$ of investor assets and loses another $0.5 \%$ to $1.0 \%$ annually to trading costs).

Indeed, investors who buy stock through equity mutual funds can lose far more. Many equity funds charge investors up-front "loads" to get into the fund, and back-end "redeinption fees" to get out of the fund. Morningstar, Inc., supra note 188, at 18. The highly rated Fidelity Magellan fund, for exainple, demands a three percent "load." Morningstar, Inc., 22 Morningstar Mutual Funds, March 18, 1994, at 154. Such charges can significantly erode returns from investing in inutual funds, especially if shares are held for a short time, and thus are a cost not included in the $1.8 \%$ estimate.

201 New York Stock Exchange, supra note 31, at 89. 
trading in 1992 alone. $^{202}$ One hundred billion dollars annually is an amount that commands respect under any circumstances. The sigmificance of that figure may be better appreciated by comparing investors' annual expenditures on stock trading with their aggregate returns from stock ownership. From 1926 to 1985, the stocks in the Standard \& Poor's 500 Index yielded average annual real returns of $8.8 \% .^{203}$ If mvestors spent $1.8 \%$ of their portfolios on trading each year, stock trading reduced investors' annual returns from stock ownership by twenty percent. ${ }^{204}$ And coinpounding magnifies the effects of reduced returns. An individual who began at age twenty-five to invest $\$ 4,000$ annually in an actively-managed stock portfoho that produced a seven percent annual compounded return could retire at age sixty-five with a nest egg of $\$ 854,438$. If a passive investment strategy imcreased her annual return to $8.8 \%$, she could retire with $\$ 1,393,864-a$ nearly sixty percent increase in value.

The notion that imvestors are losing such huge amounts picking and trading stocks may at first be hard to swallow. ${ }^{205}$ Nevertheless, the actual cost may be much higher. Institutions are the securities industry's preferred customers and generally pay low commissions on their trades. ${ }^{206}$ Mutual funds with their vast portfolios also enjoy a relative advantage in researching and analyzing stocks-it

$2021.8 \%$ of a portfolio of $\$ 5.541$ trillion is $\$ 99.7$ billion.

203 Brealey \& Myers, supra note 13, at 129-131.

$204 \mathrm{Cf}$. Lowenstein, supra note 10, at 83-84 (estimating that trading costs, measured in terms of commissions and spreads, accounted for $18 \%$ of corporate earnings in 1987).

205 Other scholars who have examined trading costs have made similar estimates. See, e.g., Lowenstein, supra note 10 , at 82 (estimating that in mid-1980s, trading costs from spreads and commissions amounted to one percent of total value of equities market, not including research and portfolio administration costs); Stoll, supra note 57, at 10, 12 (finding from revenue data that imvestors lose $0.5 \%$ of value of market portfolio annually to trading costs, and speculating that research and management costs would raise that figure above $1 \%$ ); Summers \& Summers, supra note 8 , at 271 (estimating $\$ 75$ billion in trading costs in 1987).

Data on securities firm revenues also support the idea that investor losses due to speculative trading rise to this order of inagnitude. For example, in 1992, NYSE-member firms alone enjoyed $\$ 63$ billion in revenues. New York Stock Exchange, supra note 31, at 92 (including $\$ 12$ billion in commissions, $\$ 17$ billion in trading and investments, $\$ 3$ billion in interest on custoiner's debts, $\$ 3$ billion on inutual fund sales, and $\$ 18$ billion in other income, including fees for investment advice and counsel, service charges, and dividends and interest on investments). Those revenues exclude the earnings of pension funds, mutual funds, non-NYSE firms, mvestment advisors, and the financial press.

206 See Wiles, supra note 194. 
takes no more effort to value 100,000 shares of General Motors than it takes to value 100 shares. Similar economies of scale reduce institutions' administrative expenses relative to the values of their portfolios. Mutual funds' expense ratios consequently may provide a conservative estinuate of the aggregate costs of stock trading. ${ }^{207}$

Of course, not all stock trades are based on disagreement. Some portion of stock trading can be attributed to investors who are seeking liquidity, balanced portfolios, or tax benefits, rather than trying to beat the market. Sucli nonmistaken traders need brokers and dealers just as the HE traders do. They also need to administer their portfolios and to gather information when setting the prices at which they buy and sell. Thus, some portion of aggregate trading costs can be attributed to value-adding trading. The evidence reviewed im Part $I I$ suggests, lowever, that value-adding transactions account for only a fraction of the trading-and a fraction of the costs imcurred-in today's markets. Even under the highly conservative assnmption that HE trading is responsible for only lialf of investors' annual trading costs, investors are squandering $\$ 50$ billion or so annually on transactions that bring them, on average, no benefit. ${ }^{208}$

Where does that $\$ 50$ billion or more go? Much of it goes to salaries, including the salaries of nearly 500,000 securities and commodities brokerage firm employees, ${ }^{209}$ over 200,000 investment

207 Compare supra note 197 and accompanyimg text (noting that funds lose $0.4 \%$ of portfolio annually to commissions and spreads) with supra note 205 (giving conservative estimate that investors in the aggregate pay $0.5 \%$ annually in commissions and spreads) and supra note 200 (noting $1.8 \%$ figure excludes significant investor losses from mutual fund front- and back-end loads and fees).

208 Evidence that eliminating speculative trading would greatly reduce investors' annual losses can be found by comparing the overall performance of stock index funds that do not trade speculatively with the performance of actively managed funds that do. See The Vanguard Group of Inv. Cos., supra note 199, at 2 (estimating that average equity fund has expense ratio of $1.3 \%$ of investor assets and loses another $0.5 \%$ to $1.0 \%$ annually to trading costs whereas Vanguard Index Fund loses ouly $0.3 \%$ of assets to such expenses); Waguer, supra note 30 , at 17 (estimating that managed funds underperform index funds by 1.0 to $1.5 \%$ annually, presumably due to greater trading costs).

2091993 Statistical Abstract, supra note 2, at 421 tbl. 662 (estimating that there are 438,000 employed by securities and commodities brokers in 1992, up from 425,000 in 1990 and 227,000 in 1980); see also New York Stock Exchange, supra note 31, at 94 (estimating 478,000 employed in securities industry in 1993, up from 447,100 in 1992). 
and holding company einployees, ${ }^{210}$ and 20,000 registered investinent advisors. ${ }^{211}$ Investors also pay for the offices, communications equipinent, and computer systeins used by brokerage houses, pension and inutual fund companies, and exchanges. Another part of traders' inoney goes to services that analyze and report on compamies, industries, and the economy, from private newsletters such as Value Line and Morningstar Mutual Funds to glossy magazines like Fortune and Forbes. In short, the money goes to support the industry colloquially known as "Wall Street," as well as the myriad derivative enterprises that follow and feed on it. ${ }^{212}$

Paying people to act as brokers, dealers, analysts, fund inanagers, and business reporters does, of course, create jobs, but so does paying people to dig ditches and then fill thein in again. ${ }^{213}$ If no one benefits froin digging and refilling ditches, paying soineone to perform this task rather than to engage in a more useful activity is a waste of resources. Similarly, if most of the hopeful investors who buy and resell more than half of all outstanding corporate equities each year ultimately fail to meet their objective of beating the inarket's return, a good portion of the $\$ 100$ billion that they spend maintaining an active and thriving secondary inarket also is wasted.

\section{Welfare Losses from HE Trading's Distortive Effects on Stock Prices}

The discussion thus far has focused on the likehhood that, in a world of imperfect information, investors' rational but mistaken

2101993 Statistical Abstract, supra note 2, at 421 tbl. 662 (estimating 233,000 employed by holding and other mvestment offices in 1992, up from 222,000 in 1990 and 115,000 im 1980).

211 SEC, supra note 185, at 38 (estimating 20,000 registered investment advisors in 1993, up from 18,000 in 1992).

212 Cf. Robert Lenzner \& William Heuslein, The Age of Digital Capitalism, Forbes, Mar. 29, 1993, at 62,64 (noting that Wall Street has gone from absorbing $0.5 \%$ of Gross Dounestic Product a decade ago to absorbing $1 \%$ today).

213 Nobel laureate James Tobin made this point when he suggested:

[W]e are throwing more and more of our resources, mcluding the cream of our youth, into financial activities remote from the production of goods and services, into activities that generate high private rewards disproportionate to their social productivity. I suspect that the immense power of the computer is being harnessed to this "paper economy," not to do the same transactions more economically but to balloon the quantity and variety of financial exchanges.

Tobin, supra note 10 , at $14-15$. 
belief that they can profit by speculating in corporate equities leads them to dissipate substantial wealth researching and trading stocks. HE theory suggests that the mirage of trading profits also may impose a second, hitlierto unrecognized, form of social cost. That cost arises from speculation's capacity to distort aggregate imvestor demand for stocks $\mathrm{m}$ a fashion that may lead imvestors to invest too little or too much in corporate equities.

The opportunity to speculate distorts investor demand for stocks because imvestors who trade hoping to beat the market perceive ex ante opportunities for profit that do not, on average, actually exist. The illusion of potential gain can cause imvestors to purcliase less corporate equity than they would otherwise purchase because a "false substitution" effect leads them to choose instead to mvest a portion of their assets im research and trading. This effect is dubbed a false substitution effect because it causes investors to regard buy-and-hold and active trading as substitute strategies for making money in stocks, and therefore erroneously to mvest resources in trading when they imight otherwise use those resources to purchase more shares. ${ }^{214}$ Thus, the mvestors who spend fifty bilhon dollars or more annually on researching and trading equities on the secondary markets might mstead use that fifty billion dollars to purchase more stocks but for their mistaken belief that they will gain from trading.

The HE model also suggests, however, that the false substitution effect may be countered by a second distortive effect. Investors who believe that they can outperform the market by trading may put more money into stocks than they would otherwise, because they mistakenly perceive that they can imcrease their returns on equity ownership by trading. This contrary effect may be termed a "false valuation" effect, as speculators' erroneous belief that they can earn higher rates of return on their stock portfolios by trading leads them to value stocks more highly. False valuation effects offer an explanation for the puzzling historical phenomenon of speculative "bubbles," where asset prices rose far above reasonable estimates of value before the bubble burst and prices returned to

214 Cf. Evan Schulman, The Revolution in Securities Trading, in Association for Inv. Management \& Res., supra note 29, at 10, 12 (suggesting that trading in stock options "represents business lost to the primary stock markets"). 
normal ranges. ${ }^{215}$ During the famous seventeenth-century Tulip Bubble, for example, Dutch collectors speculating in tulip bulbs supposedly drove prices up twenty-fold in a single inonth (followed by an even greater decline in the following inonth). ${ }^{216} \mathrm{HE}$ theory counsels that such peculiar phenoinena inay be a consequence of adding, and then subtracting, large numbers of optimistic speculators laboring under a false valuation effect to inarkets previously composed mainly of consumers. ${ }^{217}$

Because the false substitution and false valuation have countervailing effects, it is impossible to judge a priori whether speculative secondary market trading causes investors to invest too little or too much in stocks. But unless the two effects exactly offset each other, $\mathrm{HE}$ theory suggests that speculative trading distorts investor demand for corporate equities. ${ }^{218}$ This distortive effect is different from the inevitable fundamental value inefficiencies that arise in a market where prices reflect the aggregate deinand of many investors with limited and differing information. ${ }^{219}$ The false substitution and false valuation effects reflect the possibility that rational investors working on imperfect information can inake mistakes not only about stocks' fundamental values, but also about the likely returns froin trading vis-á-vis a buy-and-hold strategy. The latter error leads the self-selected, optimistic subset of investors who speculate in stocks persistently either to overinvest or underinvest in equities.

215 See Burton G. Malkiel, A Random Walk Down Wall Street 34-50 (5th ed. 1990) (discussing "bubbles").

216 Id. at 35-38.

217 Although the stock markets have had their share of bullish bubbles, see 1 Loss \& Sehgman, supra note 16 , at 3-5, generational effects are likely to ensure that speculators are always present in some proportion in the market, so that false substitution and valuation effects are likely to be chromic. See supra notes 72-79 and accompanying text.

218 That the false substitution and false valuation effects counteract suggests that HE trading in stock markets may present an example of "the theory of second best"-i.e., an example of two market failures that work against each other so that eliminating one source of failure while allowing the other to persist would actually leave society worse off. See R.G. Lipsey \& Kelvin Lancaster, The General Theory of Second Best, 24 Rev. Econ. Stud. 11 (1956-1957).

219 See supra notes 116-32 and accompanying text. In particular, although nonmistaken traders and $\mathrm{HE}$ traders alike suffer ignorance of stock values, only the latter group suffer false substitution and false valuation effects because only the latter mistakenly perceive opportunities to profit from speculative trading. 
From a social perspective, whether the false substitution and false valuation effects are cause for concern depends in large part on the social role stock prices play in allocating real resources. Commentators frequently assert that stock prices that accurately reflect stocks' fundamental economic values are essential to ensure the efficient allocation of investment capital and other resources. ${ }^{220}$ Stock markets are described as "mechanism[s] for channeling resources to their most productive uses in the economy"221 and "signaling" devices "important to economy-wide allocational efficiency."222 Most commonly, stock market prices are believed to determine how investment capital is allocated among firms. ${ }^{223}$ Accurate stock prices are thought to ensure that well-managed, promising corporations can raise capital easily by selling their shares at high prices whereas troubled businesses will find it harder to attract investors' dollars. Similarly, it is sometimes argued that stock prices act as signals of a firm's econoimic health in the markets for managers and for corporate control. ${ }^{224}$

220 See Barbara A. Banoff, Regulatory Subsidies, Efficient Markets, and Shelf Registration: An Analysis of Rule 415, 70 Va. L. Rev. 135, 170 (1984) (stating that stock market prices are "important to economy-wide allocational efficiency and impact[ ] on all producers"); Kiefer, supra note 6, at 889 (asserting that efficient prices are important because they are "signals which provide information that is basic to virtually all aspects of saving and investınent"); Stightz, supra note 9, at 107-08 (describing information signaling function of market); Stout, supra note 23, at 615-16 (stating that it is a "fundamental premise" of securities culture that accurate stock prices are desirable because they "influence the production, distribution, and consumption of goods and services in the economy"); cf. Lewis D. Solomon \& Howard B. Dicker, The Crash of 1987: A Legal and Public Policy Analysis, 57 Fordham L. Rev. 191, 237 (1988) ("[P]rice limits and trading lalts may impair the abihty of the stock market to allocate capital resources efficiently to those firms who will use them in the most productive fashion.").

221 Kiefer, supra note 6 , at 896.

222 Banoff, supra note 220 , at 170 .

223 See Stiglitz, supra note 9, at 107-09 (noting that commentators frequently argue that stock prices are central to the allocation of investunent capital); Stout, supra note 23, at 642, 643 n.167 (citing authorities claiming that capital allocation is markets' "most important" function); see also William J. Baumol, The Stock Market and Econoumic Efficiency 4 (1965) (stating that the stock market is the "allocator of capital resources par excellence"); Kahan, supra note 104, at 1010 ("[I] naccurate stock prices may lead to significant misallocations of capital. Companies whose stock is overvalued may raise too much equity and overimvest. On the other hand, compamies whose stock is undervalued may find it costly or impracticable to obtain sufficient capital from alternative sources, and thus underinvest.").

224 See Kahan, supra note 104, at 1028-29, 1035-37 (suggesting that prices influence selection and compensation of managers as well as choice of takeover targets); Stout, supra note 23 , at $678,685-86$ (same). 
If this view is correct, wholesale distortions in stock prices due to false valuation and false substitution effects pose a serious social problem. The notion that stock market prices play a significant role in allocating capital and other resources is, however, controversial. $^{225}$ The possible economic irrelevance of stock market prices was dramatically highlighted on October 19, 1987, when the Dow Jones average plunged twenty-three percent in a simgle day's trading with no noticeable effect on the econouny. ${ }^{226}$ Assuming some comrection, however, stock mispricing seems most likely to lead to allocative mefficiency in two situations: when mispricing persists over large periods of time $\mathrm{e}^{227}$ and when mispricing filters down to the primary market for new corporate issues. ${ }^{228}$

Short-lived distortions in stock prices are unlikely to have significant allocative effects because economic decisions influenced by share price, such as a firm's decision to replace its management team, normally are made over periods of months or years. ${ }^{229}$ Chronic price distortions, however, can affect such choices. Because the false valuation and false substitution effects of HE trading are persistent, ${ }^{230}$ they may pose a significant risk of resource misallocation.

Stock mispricing also may have a direct misallocative effect when mispricing occurs in the primary markets where corporations raise investment capital. This is because, whereas secondary market transactions only redistribute existing wealth among mvestors, pri-

225 I have argued elsewhere at length that the securities culture's emphasis on enhancing stock market efficiency, especially in the short run, is misguided because secondary stock prices have only tangential effects on real resource allocation. See Stout, supra note 23.

226 See Paul Farhi, Dire Forecasts Never Came to Pass, Wash. Post, Oct. 19, 1988, at F1 (reporting that crash had had little effect on economy); Karen Pennar, It's Almost as if It Never Happened-Almost, Bus. Wk., Apr. 18, 1988, at 56 (reporting that six months after October 19,1987, market crash had hittle effect on macroeconomy).

227 See Stout, supra note 23, at $656 \mathrm{n} .223$ (arguing that persistent distortions may lead to mispricing of new issues).

228 See Stout, supra note 23, at 708 (arguing that in contrast to trading market prices, issues prices do affect the allocation of capital).

229 For example, a firm will not try to finance a project through the sale of "overvalued" stock unless it beheves overpricing will continue for some time because preparing an offering can take months, and during that time the issuer faces the risk that the offering price will change. See id. at 666 n.272 (asserting that only persistent mispricing will influence decisions to issue stock).

230 See supra note 217 (noting that false substitution and false valuation effects will likely be chromic). 
mary market prices can determine which firms receive capital to invest and how much. ${ }^{231}$ The false substitution and false valuation effects associated with HE trading are likely to have a direct distortive effect on new issues prices. Investors who purchase newly issued shares usually can speculate in those shares in the secondary markets immediately after issuance, leading them to systematically undervalue or overvalue new issues just as they undervalue or overvalue outstanding issues. Thus, to the extent that new issues prices influence the allocation of capital among firms, ${ }^{232}$ the false substitution and false valuation effects associated with $\mathrm{HE}$ trading pose a further risk of misallocation.

The ambiguous connection between stock prices and real resource allocation makes the magnitude of any welfare losses from false substitution and false valuation effects uncertam. But whatever their maguitude, losses due to $\mathrm{HE}$ tradings' distortive effects on prices are just as inuch a social cost of speculation as the losses arising from investors' mistaken devotion of scarce resources to the negative-sum game of stock-picking and trading. ${ }^{233}$

\section{B. The Social Benefits of HE Trading}

Speculative stock trading clearly is costly to both stock traders and society as a whole. Yet from an economic perspective, speculative trading may still be desirable if it provides external social benefits exceeding its costs to traders and society. Commentators frequently assert that speculative trading does provide social bene-

231 Kahan, supra note 104, at 1008; Stout, supra note 23, at 642-44.

232 Corporations generally satisfy more than $95 \%$ of their capital needs with retained earnings or debt financing, neither of which are significantly affected by share price. See Stout, supra note 23, at 647 (noting that between 1973 and 1982, net stock issues provided an annual average of only $2.1 \%$ of corporate funding). Thus mispricing new issues may affect the allocation of capital only to those firms unable or unwilling to avail themselves of the nsual sources of funding. See Kahan, supra note 104, at 1009 (suggesting that stock price may influence capital allocation when corporation does not have access to usual sources of funding). The fact that most firms can raise imvestment capital from other sources thus suggests that stock price maccuracies, mcluding imaccuracies due to HE trading's false substitution and valuation effects, may not necessarily lead to significant welfare losses from capital misallocation.

233 The possibility that speculation can distort asset prices by inflating perceptions of the potential returns from owning and trading an asset also may be of relevance to other markets, such as currency and commodity markets, where asset prices have clearer allocative consequences. See infra notes 313-35 and accompanying text (exploring HE theory's inplications for other markets). 
fits beyond any benefit to trading parties by increasing both the hquidity ${ }^{234}$ and the efficiency ${ }^{235}$ of inodern stock markets. Careful analysis reveals, however, that the marginal liquidity and efficiency contributions of HE trading in today's high-volume markets are likely to be significantly outweighed by their marginal costs.

\section{HE Trading and Market Liquidity}

"Liquidity" refers to an investor's ability to sell an asset quickly without having to offer a discount from the prevailing market price. ${ }^{236}$ High-volume stock inarkets with large numbers of traders and high levels of trading are said to be hquid because in such markets there is a high likelihood that a seller can find a prospective buyer (and vice versa). ${ }^{237}$ Conversely, in a "thin" or "illiquid" market with little turnover, the shareholder who wants to convert her investment into cash may either have to wait for a buyer to appear or sell at a below-market price to a professional dealer who makes a living providing hquidity to those willing to pay her bid-ask spread. ${ }^{238}$

Speculative trading can contribute to market hquidity by imcreasing both the number of traders and the frequency of trading in the inarket. Liquid secondary inarkets, in turn, are thought to provide a social benefit by encouraging capital investment. Because investors desire hquidity, they value assets that can be quickly resold more highly than assets that are difficult to convert into cash. The promise of a liquid secondary inarket is thought to encourage

234 See, e.g., Hazen, supra note 6, at 1005 ("[S]peculators provide additional liquidity in the markets."); see also Scliwert \& Seguin, supra note 8, at 10 (stating that reducing trading volume liarms liquidity); Kiefer, supra note 6 , at 888 (suggesting the same).

235 See, e.g., Posner, supra note 7, at 445 ("[S]peculation serves the salutary purpose of enabling the rapid adjustment of prices to current values."); Repetti, supra note 12 , at 621 (arguing that imvestors looking for mispriced securities bid up prices of undervalued stocks and sell overpriced stocks, moving prices toward fundamental value); see also Schwert \& Seguin, supra note 8 , at 8 ("[M]ost economists take as canon the belief that an increase in the efficiency of a financial market is valuable."); Kiefer, supra note 6, at 888-89 ("[O]ne of the most basic objectives of the financial markets is determining the 'correct' prices of securities, or, in economic terminology, determining efficient prices.").

236 See Kiefer, supra note 6 , at 888.

237 See id. (stating that reducing trading volume lrarms hquidity); see also Schwert \& Seguin, supra note 8, at 10 (notimg that transfer tax that reduces trading liarms liquidity).

238 See supra note 144. 
investors to purchase newly issued stocks, lowering firms' cost of capital. ${ }^{239}$

Although the liquidity benefits claim has merit, a number of scholars have criticized the prevailing enthusiasm for highly liquid stock markets for ignoring the costs associated with such markets. ${ }^{240}$ The first and inost obvious cost associated with promoting hquidity by encouraging speculative trading is the cost of speculation itself, especially the cost of the resources squandered by investors on researching and trading. The second and more subtle cost arises from the possibility that liquid secondary markets encourage investor "short-termism" that deters shareholders from takmg an active role in momitoring their firms' managers. ${ }^{241}$

As noted earlier, investors spend $\$ 100$ billion or inore aumually researching and trading stocks in the secondary inarkets. ${ }^{242}$ Any

239 See Kiefer, supra note 6, at 888 (arguing that investors desire liquidity and thus value liquid assets more highly); Stiglitz, supra note 9, at 108-10 (describing argument that liquidity encourages investors to buy stocks, including newly issued slrares).

This argument implicitly presumes that new issues sales are worth fostering because, unlike mistaken HE trades, such transactions are mutually beneficial ex postcorporations get capital for investment, while investors gain a return on savings they might otherwise put under a mattress. Secondary market trades motivated by investors' liquidity, portfolio-balancing, or tax concerns may also be mutually beneficial. See supra Part II.A (discussing nonmistaken trading). Thus the hquidity added by speculating HE traders may provide a second social benefit by lowering the costs of nonspeculators' trades. Speculative transactions appear to far outnumber nonspeculative trades, however. See supra Part II.B. It would make hittle sense to pay commissions, spreads, and research costs on 10 speculative trades just to lower costs on one nonspeculative trade.

240 See, e.g., Lowenstein, supra note 10, at 81-87; Stiglitz, supra note 9; Summers \& Summers, supra note 8 .

241 A third cost that some observers associate with highly liquid markets is an increase in stock price volatility that discourages investors from putting their money into stocks, including newly issued shares. See Schwert \& Seguin, supra note 8, at 10 (noting that soine argue that taxes that reduce volatility will increase value of stocks); see also Stiglitz, supra note 9, at 108,110-12 (arguing that less trading will lead to less volatility, making it easier for firms to raise capital). The relationship between trading and volatility is unclear, however. Kiefer, supra note 6, at 890 (stating that empirical evidence suggests that transfer tax that reduces trading "would not affect volatility one way or the other"); Repetti, supra note 12, at 595 ("[S]tudies are inconclusive as to whether speculating increases or decreases stock market volatility."). Moreover, because new information naturally leads to changes in stock prices, it is unclear why "stable" markets are inherently better than "unstable" markets. See Hart \& Kreps, supra note 12, at 930 ("[W] hether or not speculation stabilizes prices is in some sense the wrong question. One really ought to be interested in the welfare implications of speculation. One may feel intritively that price stabilization is 'good', but, if so, one's intuition is faulty." (citation ounitted)).

242 Supra notes 193-207 and accompanying text. 
defense of secondary market trading premised on its supposed liquidity benefits necessarily presumes that liquidity that helps corporations sell new issues is worth at least that amount. The injudiciousness of that presumption, however, is revealed when one considers that the annual costs of secondary market trading likely equal or exceed the total amount of capital that firms raise from new issues in the first place. ${ }^{243}$ In the five-year period from 1988 through 1992, U.S. firms underwrote an annual average of only $\$ 40$ billion in common stock issues. ${ }^{244}$ Even 1992, a banner year for new issues, saw only $\$ 72$ billion in common and $\$ 29$ billion in preferred stock issues. ${ }^{245}$ Spending $\$ 100$ billion to promote an equivalent amount of capital investment makes hittle sense, especially when most firms can raise investment funds from other sources. ${ }^{246}$

If the primary purpose of secondary stock markets is to encourage capital investment, society might be just as well off without secondary markets. But we need not choose between a highly speculative secondary market that provides liquidity but costs $\$ 100$ billion amually and no secondary market at all. Even if eliminating all $\mathrm{HE}$ trading reduced today's $\$ 3$ trillion trading market by an order of magnitude, the remaining $\$ 300$ billion market surely would be large enough to provide reasonable hquidity for most investors. ${ }^{247}$

243 See Lowenstein, supra note 10, at 80 ("[T] he value of [new stock] issues is roughly matched by the cost of trading the old ones."); Stiglitz, supra note 9, at 109 (noting that although secondary market is thought to encourage new equity issues, "it seems to do so hittle of this at such great cost.").

244 Securities Indus. Ass'n, supra note 24, at 947.

245 Id.

246 See supra note 232 (noting that most corporations prefer to rely on nonequity sources to finance investment, including debt and retained earnings).

247 See Kiefer, supra note 6, at 888 (suggesting that U.S. financial markets, including narkets for stocks of major corporations, are so highly hiquid that a transfer tax that discouraged trading would have imconsequential effect on hquidity); Stiglitz, supra note 9, at 109 (suggesting that for widely traded stocks, transfer tax that discourages trading unlikely to have significant effect on liquidity).

Of course, for relatively sunall and unknown firms, a significant decrease in HE trading might require investors to seek liquidity from professional dealers rather than from other traders, as investors in very small firms do today. Even in such a case, however, the cost of purchasing liquidity from a dealer should be limited to the reasonable costs of storage and risk bearing. See supra note 144. 
As noted earlier, during the 1960s and early 1970s fixed broker commissions, together with federal and New York state stock transfer taxes, ensured that traders paid far higher costs than they do today. ${ }^{248}$ Not surprisingly, slare turnover on the NYSE during that period was inuch lower, averaging only about ten to twenty percent annually. ${ }^{249}$ Yet the new issues markets of the late 1960s and early 1970s were viewed as "hot" markets. ${ }^{250}$ The liquidity benefits defense of speculative trading suffers from the erroneous assumption that if some hquidity is good, more is better. ${ }^{251}$ Although speculative $\mathrm{HE}$ trading adds liquidity to an already liquid market, it adds very little, and at great expense. From an economic perspective, trying to promote liquid markets by encouraging investors to trade on their differing expectations seems a bad bargam.

The social costs of building liquidity by encouraging speculative trading may be even greater if, as some scloolars have charged, hquid markets encourage shareholder "short-termism." A fundainental problem of modern corporate life is the separation of ownership (held by the firm's shareliolders) and control (held by the board of directors and top management). ${ }^{252}$ The separation of ownership and control creates opportunities for managers to use their powers to pursue their own interests and feather their own nests at the expense of the company and its shareholders. Shareholders can reduce the likehihood of such mefficient behavior by closely momitoring their managers and replacing those who seem lazy or venal. The critics of highly hiquid, high-turnover stock markets charge, however, that even very large shareliolders, such as

\footnotetext{
248 Supra notes 59-62 and accompanying text.

249 Supra notes 63-64 and accompanying text.

250 See David L. Ratner \& Thomas L. Hazen, Securities Regulation 875 (4th ed. 1991); David Clurman, Controlling A Hot Issue Market, 56 Cornell L. Rev. 74 (1970); see also John Brooks, The Go-Go Years (1973) (referring to the 1960s as "go-go" years for primary and secondary stock markets).

251 As Professor Louis Lowenstein has observed, "Liquidity is a good thing, but we are drowning in it." Lowenstein, supra note 10 , at 81.

252 See Eugene F. Fama \& Michael C. Jensen, Separation of Ownership and Control, 26 J.L. \& Econ. 301 (1983); Michael C. Jensen \& William H. Meckling, Theory of the Firm: Managerial Behavior, Agency Costs and Ownership Structure, 3 J. Fin. Econ. 305 (1976).
} 
pension funds and mutual funds, are unlikely to ride herd on management if they expect to hold their shares for only a short time. ${ }^{253}$

$\mathrm{HE}$ theory supports the claim that speculation encourages shorttermism by suggesting that short-termism may be another false substitution effect. Investors who regard short-term, speculative trading and long-term, mvolved ownership as substitute strategies for increasing their returns from stocks may mistakenly select the former approach over the latter. ${ }^{254}$ The siren song of tradimg profits may distract shareholders from momitoring shirking managers. As a practical matter, the magnitude of any social losses resulting from investors' mistaken preference for short-term trading over long-term involvement is uncertain. Even in the absence of speculation, freerider effects and a host of other institutional and legal restraints would likely discourage even very large shareholders from becoming too actively involved in their firm's affairs. ${ }^{255} \mathrm{Nev}$ ertheless, the lure of speculative profits almost certainly mcreases investor unwillingness to spend much time or effort policing management.

In sum, the problems of excessive trading costs and investor short-termism caution against an excessive emphasis on the bene-

253 See, e.g., Lowenstein, supra note 10, at 91-92 (suggesting that ability to sell shares quickly discourages investors from momtoring management, thereby harming firms' economic performance); see also Summers \& Summers, supra note 8, at 273-74 (suggesting that transaction tax might encourage investors to momitor management rather than exit).

Another variant of short-termism addresses the possibihty that investors' einphasis on short-run trading profits leads corporate managers to focus inyopically on boosting nearterin earnings and prospects, while sacrificing investunent strategies designed to enhance firms' long-run profitability. See, e.g., Kiefer, supra note 6, at 893 (noting short-termism argument). Economists have criticized such claims on the grounds that as long as investors rationally value stocks according to their likely future risks and returns, any management sacrifice of long-run profitability will be recognized and will depress market prices. Schwert \& Segum, supra note 8 , at 8-9 (criticizing management myopia argument that short investor holding periods induce managers to act myopically because it assumes that long-run strategies are not reflected in market prices and is thus inconsistent with unarket efficiency); Kiefer, supra note 6, at 893-95 ("[T]he 'short-termisin' argument depends on the belief that the stock market systematically undervalues companies that pursue longterm investment projects .... This belief does not seem to be supported by the evidence.").

254 See Summers \& Summers, supra note 8, at 273-74 (implying that ability to sell quickly in liquid market tempts investors to substitute "exit" strategy over "voice").

255 Id. at 274; see Bernard S. Black, Shareholder Passivity Reexamined, 89 Mich. L. Rev. 520 (1990); John C. Coffee, Jr., Liquidity Versus Control: The Institutional Investor as Corporate Monitor, 91 Colum. L. Rev. 1277 (1991). 
fits of hquid markets without careful assessment of their costs. As John Maynard Keynes observed, scholars of finance have made a "fetish" of liquidity, assuming that more is always better than less and that more liquid secondary markets are desirable no matter what costs may be associated with them. ${ }^{256}$ Closer analysis suggests that the additional liquidity offered by HE trading carries a higher price than it is wortl.

\section{HE Trading and the Fundamental Value Efficiency of the Market}

A second social benefit often attributed to speculative stock trading is an imcrease iu market efficiency, meaning the rapidity and accuracy with which stock prices respond to new information. ${ }^{257}$ Economists and securities scholars often pay homage to the purported social benefits of efficient stock prices in ensuring the correct allocation of capital and other scarce resources. ${ }^{258}$ Once again, however, any defense of speculation premised on its benefits for market efficiency must address the question whether those benefits are worth their costs at the margin.

The assumption that speculative trades are important in incorporating new information imto stock prices overlooks the likelihood that speculation is unnecessary for such a process to occur. Even if there were no HE trading, investors would still buy and sell stocks for liquidity and portfoho-balancing reasons; presumably, they would still seek out and take into account all reasonably available information when setting prices. An analogy might be drawn to the market for single-fainily homes. High transaction costs ensure that speculators play hittle or no part in the market for simgle-family residences, where turnover is low and owners buy and sell primarily for consumption-i.e., to have a place to live. ${ }^{259}$ Yet casual observation suggests that home buyers and sellers pay close attention to information relevant to values when setting the prices at

256 Keynes, supra note 10, at 155 ("Of the maxims of orthodox finance none, surely, is more anti-social than the fetish of liquidity ....").

257 See supra notes 13, 235 and accompanying text.

258 See Scliwert \& Seguin, supra note 8, at 8 ("[M] belief that an increase in the efficiency of a financial market is valuable."); see, e.g., Kiefer, supra note 6 , at $888-89$ (asserting that basic objective of financial markets is determining correct, efficient prices).

259 See supra note 58 and accompanying text. 
which they buy or sell. Similarly, in a stock narket of investors trading primarily for liquidity, tax breaks, or a balanced portfolio, rational investors will choose prices that reflect all reasonably available information relevant to stock values.

Consequently, the argument that speculative trading furthers stock market efficiency must hinge on the notion that speculators greatly improve the efficiency of prices at the margin, both because the hope of trading profits inspires thein to seek out new information and because increasing trading volume helps move prices in the direction suggested by new information more quickly. At the margin, however, improvements in market efficiency due to speculative trades are likely to be small. Most information that speculators acquire and incorporate into price (sucl as news of a takeover bid or a change in earnings) is destined to becoine widely known in due course anyway. The social benefits of incorporating that news into prices ouly days or hours earher seem minimal. ${ }^{260}$ This is especially true given the likelihood that any resulting improvement in accuracy will likely be confined to secondary market prices, offering only negligible benefits due to improved resource allocation. ${ }^{261}$

260 See Easterbrook \& Fischel, supra note 43, at 682 (arguing that moving information into stock prices "a day or so quicker is not of much moment for allocative efficiency"); Kiefer, supra note 6, at 896 ("According to the argumeut, the social value of learning news about a company minutes or hours or eveu days earher than otherwise is negligible.").

261 See Stiglitz, supra note 9, at 107 (suggesting that "prices in the stock market play no basic informational role in the economy"); Stout, supra note 23 (questioning extent to which stock prices affect real resource allocation); supra notes 227-30 and accompanying text (noting that only secondary market mispricing that is persisteut or affects primary market seems likely to trigger resource misallocations). Because trading in the secondary markets does not provide additional capital to corporations, secondary inarket prices affect the allocation of capital to firms only indirectly, by providing information on what price investors miglit be willing to pay for newly issued shares. See Kahan, supra note 104, at 1012-13; Stout, snpra note 23, at 653-55. In the case of "seasoned" issues (i.e., issues of shares identical to those already traded in the market), secondary market mispricing may indeed have a direct influence ou a firm's decision whether to issue more shares if mispricing persists long enough for firms to act ou it. See Stout, supra uote 23, at 653-54 (asserting that secoudary market prices influence underwriters trying to price seasoned issues by signaling a "ceiling" price below which the issne should be priced). In the case of an imitial public offering, however, the signaling value of secondary market prices is quite limited-investors' varying enthusiasms for established companies say little about the market's view of a new firm's prospects. See Stout, supra note 23, at 654-56 (argumg that market prices of particular firms in secondary market provide little information to underwriters pricing initial public offerings); see also Stightz, supra note 9, at 107 (stating more geuerally that "informatiou revealed by the stock market price is not precise enough to be of much use to most firms"). 
Another highly questionable assumption underlying the market efficiency argument is the assumption that efficient market prices are necessarily accurate prices. ${ }^{262}$ As discussed earlier, HE theory predicts that a stock's market price is nothing more than the intersection of a fixed supply curve with a market demand function that aggregates the individual demands of many investors, all of whom are laboring under some degree of ignorance. No amount of speculative trading can produce "accurate" prices in such a market, even if the market is highly informationally efficient, investor disagreement and varying degrees of ignorance will ensure that stock prices bear only the roughest correspondence to their intrinsic values. ${ }^{263}$

Close scrutimy of the market efficiency benefits defense of speculative trading consequently reveals that encouraging speculation is unlikely to produce significant social benefits from improved price accuracy. The efficiency benefits claim is undermined still further by the HE trading model's implication that speculative HE trading inay actually decrease the fundamental value efficiency of market prices. As discussed earher, false substitution and false valuation effects cause HE traders systematically to undervalue or overvalue corporate equities. ${ }^{264}$ Because the relatively pessimistic investors wlio hew to a buy-and-hold strategy and trade only for liquidity or portfolio-balancing reasons are not subject to false substitution and false valuation effects, ${ }^{265}$ speculators' subjective valuations of stocks are subject to distortions that non-speculating investors' are not. In otlier words, HE traders may on average be worse judges of stock values than other traders. ${ }^{266}$ If so, adding large numbers of speculating HE traders to a market where investors already trade modest amounts of stock for liquidity or portfolio-balancing rea-

262 See supra notes 94-104 and accompanying text (noting that many legal scholars presume fundamental value efficiency follows from informational efficiency).

263 See supra notes $126-31$ and accompanying text.

264 See supra Part III.A.2.

265 See supra note 142 and accompanying text.

266 If investors enjoyed infinite lifespans, speculating HE traders might indeed become superior judges of stock values over time as $\mathrm{HE}$ traders who were bad at picking stocks lost money and were "weeded out" of the market. Generational effects ensure, however, that the pool of HE traders includes a large proportion of those whom time will ultimately expose as poor judges of stock values. See supra notes $79,87-90$ and accompanying text. 
sons actually may decrease the already questionable level of fundamental value efficiency found in the market. ${ }^{267}$

Close examination of the supposed efficiency benefits of speculative trading under the assumption of imvestor heterogeneity thus suggests that, contrary to conventional wisdom, speculative trading is unlikely to produce more accurate inarket prices and may even contribute to price inaccuracy. The alleged efficiency benefits of speculative trading are at least exaggerated, and possibly illusory.

\section{Reducing Welfare Losses from HE Trading: Some Policy Implications}

Scholars and lawmakers alike often sing the praises of inodern stock markets, adıniring their efficiency, hquidity, and ability to service millions of traders who annually trade trillions of dollars in stocks. Yet a thriving secondary inarket is enormously expensive to the traders who on average fail in their quest to outperform the market. Speculative trading in corporate equities also inay lead to social losses by distorting imvestors' demand for firms' shares and possibly, the allocation of capital and other resources. In return, speculative trading offers only a modest improvement in the market's hquidity and may actually reduce the market's fundamental value efficiency. Careful analysis of the costs and benefits of speculative trading in the light of HE theory consequently suggests that, at least in the case of stock markets, the common presumption that stock speculation benefits both speculators and society as a whole may be dangerously misleading. Speculation appears to be a form of costly market failure, a rational but ultimately liarmful activity that destroys wealtl and distorts prices while providing little in compensatory benefits.

That possibility carries a broad range of implications for the regulation of inodern equities markets. Federal securities law pursues a number of goals, chief among thein the protection of imvestors and the promotion of efficient markets that accurately price securities. HE theory suggests that pohcymakers should consider a third

267 Similarly, noise trader theorists have argued that the trading of irrational investors speculating on "noise" moves stock prices away from their values. See, e.g., Black, supra note 34 , at 532 (maintaining that because "noise trading actually puts noise into the prices ... prices will be less efficient"). 
goal as well: reducing the welfare losses that flow from speculative trading.

This Section briefly considers how lawmakers might alleviate welfare losses from HE trading. On the theoretical level, imperfect information, regarding both the true values of stocks, and investors' relative trading talents, is the source of the market failure reflected in HE trading. ${ }^{268}$ One obvious policy response might be to provide investors with the information they lack. ${ }^{269}$ In the case of stock speculation, however, the cost of providing the information needed for investors to value perfectly either corporate equities or their own trading talents is virtually infinite. Stock values depend on an obstinately indeterminate future, and only experience can reveal whether a particular investor has a knack for speculation. ${ }^{270}$ Because the information necessary to prevent speculative trading is no more available to the government (or anyone else) than to imvestors, individuals who wish to invest in corporate equities necessarily approach the market suffering some degree of ignorance about both stock values and their own prospects in the trading game. ${ }^{271}$

This does not imply, however, that welfare losses from stock speculation cannot be mitigated. At least three possible approaches can potentially reduce social losses due to speculation: (1) reducing the incidence of trading through policies that reduce the dispersion of investor opimion, (2) reducing welfare losses by

268 Uncertainty about stock values leads investors to disagree in their assessments with each other and with market prices. Uncertainty about one's own relative aptitude for trading leads an optimistic subset of investors to attempt to wring profits from their disagreement by trading despite their imtellectual recognition that stock trading is a negative-sum game. See supra text accompanying notes 35-39, 66-69.

269 This response to imperfect information can be folmd in other contexts. For instance, prescription drugs are accompanied by labels describing common side effects, and processed foods are labeled with their ingredients.

270 Investors might try to test their trading talent in advance by devising hypothetical trading strategies to observe what their returns would have been had they actually traded. Although some individuals and institutions do use "paper" trading to test the value of a particular strategy, paper trading requires investors to make an mvestment of time and effort with no risk but also no possibility of return. Moreover, because the success of many trading strategies is best gauged over a period of years, many investors feel that they simply lack the time to test the waters in this fashion.

271 The government might, however, require all stocks to carry the following label: "WARNING: Self-Selection Ensures that You Probably Are Not Going To Be as Talented at Trading as You Think You Might Be." 
reducing the costs associated with speculative trading, and (3) discouraging speculative trading through deterrent measures such as a tax, or even a prohibition, on speculative transactions.

The discussion below briefly surveys some of the advantages and disadvantages of each approach. The discussion also touches upon the HE model's implications for the present regulatory scheme, a laissez-faire approach that promotes trading while protecting imvestors primarily through antifraud and mandatory disclosure rules. The intent is not to provide a coinpreliensive slate of proposed reforms, for any specific question of securities law necessarily imphicates complex issues and pohcy concerns tllat he well beyond the scope of this Article. Rather, the following discussion illustrates how the HE model's new perspective offers important, illuminative, and often countermtuitive insiglits into many old issues.

\section{Reducing Welfare Losses from HE Trading Through Rules That Reduce the Dispersion of Investor Expectations}

In the simplified model of HE trading presented in Part I, an mvestor buys (sells) a particular stock when her subjective estimate of that stock's value exceeds (falls below) the market price by an amount sufficient to make up for transaction costs. ${ }^{272}$ Increasmg dispersion in mvestor expectations-fomenting disagreementincreases tradimg frequency because more investors will loold subjective assessments that vary enough from market price to justify trading. Conversely, reducing dispersion im expectations-encouraging agreement-decreases speculative trading and thus can reduce welfare losses from speculation. ${ }^{273}$

Absent an oracle to predict the future, some investor disagreement over stock values seeins mevitable. Nevertlieless, pohcies can be designed to reduce dispersion in investor expectations, and with it, the incidence of $\mathrm{HE}$ trading. In fact, two central doctrines in modern securities regulation, antifraud rules and mandatory disclosure rules, may serve just that purpose, albeit madvertently.

Prohibitions against fraud in the sale of securities are contained in botll the Securities Act of 1933 ("'33 Act") and the Securities

272 See snpra notes $46-51$ and accompanying text (modeling trading as function of trading costs and dispersion of investor expectations).

273 See supra notes $49-51$ and accompanying text. 
Exchange Act of 1934 ("'34 Act"). ${ }^{274}$ These federal antifraud rules are praised for advancing the efficiency of market prices and the fairness of stock inarkets. ${ }^{275}$ The HE inodel intimates that antifraud rules also may reduce the likelihood of negative-sum speculative trading. Misrepresentations regarding securities often are made for the purpose of inducing speculative purchases or sales by convincing investors that stocks are underpriced or overpriced. ${ }^{276}$ Brokers in particular may be tempted to foster investor disagreement and trading by providing investors with false and misleading information. ${ }^{277}$ Effective antifraud rules thus not only protect investors and insulate market prices from the distortive

274 See, e.g., 15 U.S.C. $\$ 77 q$ (1988 \& Supp. V 1993) (codifying section 17 of the 1933 Act, which prohibits fraud and misrepresentations in the sale of securities); 17 C.F.R. $\$ 240.10 \mathrm{~b}-5$ (1994) (providing rule 10b-5 of the 1934 Act, which prohibits fraud and misrepresentations in connection with the purchase or sale of securities).

275 See Easterbrook \& Fischel, supra note 43, at 673 ("Fraud reduces allocative efficiency."); David J. Schulte, The Debatable Case for Securities Disclosure Regulation, 13 J. Corp. L. 535, 540 (1988) (same).

276 See, e.g., Beecher v. Able, 374 F. Supp. 341 (S.D.N.Y. 1974) (describing action agamst corporation for misrepresentation in sale of debentures); Escot v. Barchris Constr. Corp., 283 F. Supp. 643 (S.D.N.Y. 1968) (same).

Another common purpose of fraud is to affect the price of a transaction that would occur anyway. See, e.g., Affiliated Ute Citizens v. United States, 406 U.S. 128 (1972) (describing claim of fraudulent omission designed to induce plaintiffs to sell at lower price). In such cases, an antifraud prohibition neither furthers nor frustrates the goal of deterring speculative trading.

More rarely, fraud nuay be used to deter a transaction. In such a case, enforcing the antifraud rules would actually increase the incidence of trading. Interestingly, case law denies standing to investors seeking to enforce the antifraud prohibition in such cases on the grounds that, if the fraud successfully deters the transaction, the plaintiff is neither a "purchaser" nor a "seller" entitled to sue. See Blue Chip Stamps v. Manor Drug Stores, 421 U.S. 723 (1975) (disnrissing action by offerees of stock who claimed defendants had fraudulently misrepresented offer as unattractive in order to deter thein froin buying on the ground that only purchasers and sellers have standing to sue under Rule 10b-5).

277 See supra Part I.D.1. Unfortunately, the value of present antifraud rules in preventing broker misrepresentation is soinewhat limited because, as a practical matter, it is difficult for investors to prove that technically truthful but highly slanted or biased advice that inspires trading is tantainount to a fraud. See supra note 84 and accoinpanying text.

This is not to say there is no hope of reducing brokers' role in fostering disagreenent. For example, requiring all communications between broker and chent to be in writing wonld make it more difficult for brokers to avoid fraud claims by disputing the content of their advice. Investors might also be given some protection from sincere but overoptimistic brokers if brokers who gave investınent advice were required to disclose their "track record" in advising other chents. 
effects of false information, but also reduce welfare losses from speculative trading by reducing the incidence of trading. ${ }^{278}$

The federal system of mandatory corporate disclosure may provide an even more effective approach to reducing dispersion $\mathrm{m}$ investor expectations. The '33 Act requires companies that publicly issue stock to file with the SEC and provide im a prospectus to investors extensive information describing both the firm and the offered security. ${ }^{279}$ The ' 34 Act requires firms whose shares are publicly traded to file regularly with the SEC extensive information regarding the firms' business, management, and financial status, and to provide similar information directly to shareholders in the form of an annual report. ${ }^{280}$ Federal mandatory disclosure rules lave been applauded for contributing in a number of ways to both the fairness and the efficiency of the market. ${ }^{281} \mathrm{HE}$ theory suggests that mandatory disclosure may serve another important social function by diminishing the investor disagreement that inspires wasteful and distortive speculative trading.

As discussed in Part I, disagreement is inevitable when investors rely on different, limited subsets of information. ${ }^{282}$ Providing all investors with the same data consequently promotes homogeneous expectations. This insight reinforces the social value of the federal mandatory disclosure scheme against conservative academics' cliarges (often based on efficient market theory) that required disclosure is either irrelevant or too expensive. ${ }^{283} \mathrm{HE}$ theory supports

278 In addition to prohibiting misrepresentations, federal antifraud rules also prohibit insider trading and stock price manipulation, both of which are forms of speculative trading. See generally Hazen, supra note $81, \S \S 6.0 .1,12.1,13.9$ (discussing manipulation and insider trading). The rules aganist insider trading and manipulation consequently also decrease the incidence of $\mathrm{HE}$ trading.

279 See id. \$§ 3.1-3.8 (stating disclosure requirements under '33 Act).

280 See id. $\$ \S 9.2-9.3$ (stating disclosure requirements under '34 Act).

281 See Coffee, supra note 29, at 722, 725-29, 751 (arguing that mandatory disclosure aids informational efficiency because information is underprovided public good); Langevoort, supra note 6 , at 781-85 (noting a variety of arguments why mandatory disclosure might enhance both efficiency and fairness of market). But see Easterbrook \& Fiscliel, supra note 43, at 692-96 (arguing that rationales for inandatory disclosure, including increasing public's confidence in market, protecting unsophisticated investors, and increasing supply of information to efficient market, are "poorly supported").

282 Supra notes $46-56$ and accompanying text.

283 See Coffee, supra note 29 , at 717-18 (describing "revisiomist" charges that inandatory disclosure produces few benefits at considerable cost); Langevoort, supra note 6 , at 778 ("Based on the so-called efficient market hypothesis, ... a growing number of critics have 
the claim that mandatory disclosure rules are needed because it suggests that, before $\mathrm{HE}$ traders actually sustam losses from trading, they are unlikely to recognize that they will benefit from uniform and timely disclosures that reduce speculation by encouraging agreement. Indeed, if they think that they might profit from others' ignorance, they might actually oppose such disclosures. As a result, shareholders left to their own devices will not demand optimal disclosure from the firms in which they invest. After sustaining trading losses, $\mathrm{HE}$ traders may recognize that ignorance that encouraged disagreenent made them worse off, but at that point, the-sadder-but-wiser HE trader can avoid losses more cheaply by simply refraining from trading.

$\mathrm{HE}$ theory also offers guidance on how disclosure requirements might be structured. For example, the SEC's "integrated disclosure" system excuses large, publicly held firms whose stock is actively traded froin providing much information directly to investors on the theory that, as long as the relevant information is filed with the SEC and available to a subset of sophisticated imvestors, it will be incorporated into an efficient market price. ${ }^{284}$ The HE model implies, however, that providing information to a small minority of imvestors promotes informational but not fundamental value efficiency and may even increase welfare losses from $\mathrm{HE}$ trading by provoking imvestor disagreement. Similarly, HE theory offers new msight into the ongoing debate over whether disclosure documents sliould be "readable" by the average investor. ${ }^{285}$ If one purpose of mandatory disclosure should be to foster agreement by

argued that the current mandatory disclosure system is unnecessary . . . ."); see also Easterbrook \& Fischel, supra note 43 , at 709-14 (discussing critique of mandatory disclosure and concluding that "there is no good evidence that the disclosure rules are beneficial").

284 See Langevoort, supra note 6, at 767 \& n.83 (describing integrated disclosure and noting that the "practical effect is that investors actually receive very hittle of the information on file" with the SEC).

285 See Homer Kripke, The SEC, the Accountants, Some Myths and Some Realities, 45 N.Y.U. L. Rev. 1151, 1164-65 (1970) (arguing that disclosure documents need not be readable by lay investor); see also Easterbrook \& Fischel, supra note 43, at 694 (maintaining that view that mandatory disclosure should cater to unsophisticated imvestors is "as unsophisticated as the investors it is supposed to protect" because informed traders in an efficient market will impound all relevant information into prices, making it unnecessary to provide that information to the remainder of investors). 
providing uniform information, disclosures that most investors find incoinprehensible do little to further tliat goal.

\section{Reducing Welfare Losses from HE Trading Through Rules That Decrease the Costs of Speculative Trading}

In addition to discouraging investor disagreement, federal mandatory disclosure rules inay play a second role in reducing social losses from speculative trading. The cost of research-that is, the cost of acquiring and analyzing the information needed to inake stock forecasts - is a major component of the expense incurred by investors who trade to beat the inarket. The mandatory disclosure system provides a broad range of information to investors quite cheaply. Thus, mandatory disclosure rules may reduce social losses from HE trading by reducing the costs of speculators' active management of their portfolios.

Legal scholars liave occasionally recognized this point by arguing that, in addition to contributing to investor protection and inarket efficiency, the mandatory disclosure system may also produce a social benefit by reducing investors' need for wasteful and duplicative researcl. ${ }^{286}$ This argument, lowever, fails to take account of the possibility that inandatory disclosure rules that reduce the marginal cost of speculation may encourage investors to speculate inore often and so lead to an increase in the total cost of trading.

Reducing the inarginal cost of speculation can increase welfare losses due to speculation because cost and trading are inversely correlated (as the costs of speculating go down, investor interest in speculating goes up). ${ }^{287}$ As an example, consider the impact on total trading costs of a substantial reduction in marginal costs that triggers an even greater increase in trading. Suppose the elimination of fixed broker commissions in 1975 reduced investors' commission costs by one-lialf, from approximately $5.0 \%$ of the value of

286 See Coffee, supra note 29, at 733-34 (arguing that mandatory disclosure system may eliminate much wasteful duplication in research); Stout, supra note 23, at 705 ("[M]andatory disclosure can be defended not because it is important for investors to have such information, but because it is important to stop [thein froin] wasting [their] resources to get it."). But see Easterbrook \& Fischel, supra note 43, at 682 (noting argument but disagreeing that inandatory disclosure is necessary to reduce waste).

287 See supra note 51 and accoinpanying text; see also Stigler, supra note 35, at 223 (explaining that searching for best bargain is part of purchase cost of a good and that consumers purchase less as search costs go up). 
a trade to about $2.5 \% .^{288}$ Suppose also that the reduction triggered a threefold increase in trading, so that the annual market turnover rate increased froin ten percent to thirty percent. ${ }^{289}$ Before deregulation, mvestors were spending approximately $0.5 \%$ of the value of their portfolios annually on commissions. Reduced commission rates result in investors spending even more; now they lose $0.75 \%$ of their portfohos annually to broker fees.

In economic terms, whether lowering the marginal costs of speculative trading increases or decreases the total costs depends on whether the demand for speculative trading is relatively elastic (small clianges in the marginal price of trading trigger large changes in demand for trading) or relatively inelastic (changes in the price of trading have little effect on the demand for trading). ${ }^{290}$ Although more empirical study is needed, the available evidence suggests that the demand for stock trading is quite elastic, so that decreases in marginal trading costs are likely to trigger disproportionately greater increases in the frequency of tradimg. ${ }^{291}$ This possibility implies that pohicies that reduce speculators' marginal costs, such as the deregulation of fixed commissions or mandatory disclosure rules that reduce inarginal research costs, may actually have the perverse effect of increasing net welfare losses from speculative trading. ${ }^{292}$

The observation that reducing inarginal stock research and trading costs can increase welfare losses from speculation should not be taken to imply that the system of inandatory disclosure sliould be dispensed with, or that securities firms should be encouraged to

288 See supra note 63 (noting that deregulation estimated to have halved institutions' out-of-pocket trading costs); supra note 57 (noting that net costs of speculation presently approximate three percent of value of trade).

289 See supra note 64 and accompanying text (noting that NYSE turnover increased from approximately $10 \%$ to $50 \%$ following deregulation).

290 See generally Stout, supra note 11 , at $1239-44$ (discussing demand elasticity).

291 See Schwert \& Seguin, supra note 8, at 19-20 (citing studies of foreign exchanges finding highly elastic demand for trading); Kiefer, supra note 6, at 886 (estimating that $0.5 \%$ transfer tax would cause stock volume to decline by $7.9 \%$ ); see also supra notes $63-64$ and accompanying text (noting that deregulation of brokers' commissions between 1968 and 1975 halved institutions' out-of-pocket trading costs and that turnover on NYSE rose froin $10 \%$ to $50 \%$ between 1960 and 1987 ).

292 Similarly, the development of derivative financial instruments such as stock index futures and index options may increase net welfare losses from stock trading, because the costs associated with trading derivatives are even lower than the costs associated with trading equities. Infra notes $330-31$ and accompanying text. 
engage in inonopolistic price-fixing. As noted earlier, federal securities law addresses a number of goals. Altlough HE theory suggests that reducing social welfare losses from speculative trading certainly is important, it slould not be regulators' sole objective. Rather, the point is that the challenge of controlling excess speculation, although not intractable, raises subtle and coinplex issues.

\section{Reducing Welfare Losses from HE Trading by Taxing or Prohibiting Trading}

Policies that encourage imvestors to develop lomogeneous expectations can reduce the incidence of wasteful speculation. In a world of imperfect information, however, investor disagreement on stock values is unlikely to be entirely eliminated. A second alternative, trying to control welfare losses from speculative trading by reducing marginal researclı and trading costs, may actually mcrease total welfare losses if demand for stock trading is highly elastic. This possibility, lowever, suggests a third (and perliaps more obvious) solution to limiting social losses from speculation: increasing the marginal costs of stock speculation eitluer by imposing a tax on sucls trading or prohibiting it altogether. ${ }^{293}$

Botli the Busli and the Clinton administrations considered proposals to reinstate a federal stock transfer tax by imposing a fee of no more than $0.5 \%$ of value on transactions in corporate equities and other securities. ${ }^{294}$ Those proposals died in a storm of protest (and lobbying by the securities industry) ${ }^{295}$ that imcluded debates

293 Increasing the costs of speculation through a tax or prohibition decreases the incidence of trading without providing any further revenues to the securities industry (as reinstating fixed broker commissions or eliminating mandatory disclosure that substitutes for private research would) and so is effective in reducing welfare losses from speculation whether deinand for stock trading is elastic or inelastic.

294 See Schwert \& Seguin, supra note 8, at 1-3 (describing Bush and Clinton proposals); Kiefer, supra note 6, at 885 (describing Bush administration and Congressional Budget Office proposals).

295 See Schwert \& Seguin, supra note 8, at 23 (asserting that the wisdoin of a stock tax is likely to be "hotly debated"); Joseph A. Grundfest \& John B. Shoven, Adverse Implications of a Securities Transactions Excise Tax, $6 \mathrm{~J}$. Acct. Auditing \& Fin. 409, 409-10 (1991) (noting that stock tax proposal "encountered a storm of protest from . . . the congressional and academic communities" and that it "was the subject of extensive lobbying by the securities and commodities industries"); see also Joseph A. Grundfest, The Damning Facts of a New Stocks Tax, Wall St. J., July 23, 1990, at A10, (asserting that stock tax has "no evident justification" " and would likely "destroy part of the U.S. financial 
over whether such a tax would raise revenue, its effect on capital formation, its progressivity, its advantages as compared to a capital gains preference, difficulties in implementation, and so forth. ${ }^{296}$ This Article does not join that passionate and often partisan debate by recommending any particular size or type of tax but rather simply explores the potential value of some tax-including that extreme form of tax, the prohibition-in reducing welfare losses due to speculative trading. ${ }^{297}$

Taxes are usually implemented to raise revenue. But taxes also can be used to deter undesirable behavior by raising the cost of that behavior. ${ }^{298} \mathrm{~A}$ tax to deter behavior resembles a prohibition except that a tax raises the cost of an undesired behavior by a finite amount, whereas a prohibition (assuming perfect enforceinent) raises cost infinitely. In the case of stock trading, both forms of regulation pose the similar economic problem of deterring desirable as well as destructive transactions.

In understanding the dilemma posed by a tax or prohibition on securities trading, it is useful to recall the two alternative market models presented in Parts I and II, the HE trading model and the value-adding model. ${ }^{299}$ The HE trading model describes purely speculative markets im which investors buy and sell stocks in the

Inarket" (quoting Richard Darman)); Michael Kinsley, Stock Response, New Republic, Aug. $20 \& 27,1990$, at 4 (questioning tax that "create[s] friction in the wheels of commerce" and whether "government know[s] better than the free market"); Robert E. Norton, The Silly Pusl To Tax Stock Trading, Fortune, Dec. 18, 1989, at 151 (calling the tax "a dumb idea").

296 See sources cited supra note 295 (arguing against tax).

297 The transfer tax proposal was supported by a small but esteeined group of economists and policymakers who favored it not only to raise revenue, but also (in the words of Nobel laureate James Tobin) to "throw[] sand in the gears'" of financial markets they perceived as exhibiting too inuch short-term trading and speculation. See Schwert \& Seguin, supra note 8, at 1 (noting tax supported by Joseph Stiglitz of Council of Economic Advisors and Lawrence Summers of Department of the Treasury); Kinsley, supra note 295 , at 4 (quoting James Tobin and also noting the support of then-Treasury Secretary Nicholas Brady, "who is obsessed with the idea that American finance is plagued by too much wasteful speculation").

298 The two goals are in tension with one another. A tax that deters substantially raises little revenue, and a tax that deters completely raises no revenue at all. Conversely, if deinand for speculative trading proved be highly inelastic and a stock transfer tax did not significantly deter trading, policymakers would be offered a consolation prize in the form of increased revenue.

299 See supra notes $22-64,137-148$ and accompanying text (HE and value-adding trading inodels). 
hope of profiting on resale by successfully forecasting changes in future prices. Disagreement is a prerequisite for such trading because disagreement permits both parties to the trade to expect to increase their wealth ex ante, even though trading mevitably reduces the traders' aggregate net wealth ex post. Given perfect information and homogeneous expectations, no trading would occur. Trading in the HE market thus reflects a form of welfaredecreasmg market failure, implying that a tax or prohibition that discourages trading leaves traders and society better off.

In contrast, according to the value-adding model, investors buy and sell stocks not because of differences in their expectations for the future, but because of differences in their present preferences for hquidity, capital gains or losses, or diversification. Such trades are mutually beneficial ex post as well as apparently mutually beneficial ex ante and would occur even if investors shared hoinogeneous expectations. Because trading leaves both parties to the trade better off, the value-adding model imphies that trading is a socially desirable activity and that restricting trading leads to welfare losses. The distinction between $\mathrm{HE}$ inarkets and value-adding markets therefore imphes that, as a general rule, a tax or prohibition on stock trading may be appropriate if secondary stock markets are purely or primarily speculative. Conversely, a transfer tax or prohibition on trading leads to welfare losses if stock markets refiect primarily value-adding trades inspired by differences in consumers' preferences that would exist even if consumers shared homogeneous expectations.

Markets can reflect a mixture of both value-addmg and speculative tradimg. For exainple, although markets for physical commodities such as apples normally are dommated by the sort of valueadding transactions that would occur even if all market participants held identical expectations for future prices, ${ }^{300}$ such markets may

300 That does not imply that consumers cannot make welfare-reducing mistakes as a result of imperfect information im those markets. Consumers may make welfare-reducing trades because they are mistaken about their own preferences. Thus John spends one dollar to purchase a mango ice cream that he discovers, upon tasting, he detests. Consumers with imperfect information may also make mistakes about the quality of the goods they purchase, as when Mary buys a car that proves to be a lemon. It is far more difficult, however, to detect and prevent such mistakes in a largely value-adding market than it is to detect mistakes in an HE trading market, where the laws of arithmetic predict that virtually all transactions are welfare-reducing. 
occasionally succumb to speculation (as the Tulip Bulb frenzy confirmed). ${ }^{301}$ Nevertheless, the evidence examined in Part II suggests that the majority of trades in modern stock markets are welfarereducing trades driven by investor disagreement. ${ }^{302}$ That evidence supports the notion that regulation that deters speculation by taxing or prohibiting stock trading will produce net welfare gains.

Of the two forms of regulation, a tax seems clearly preferable to a complete prohibition on stock trading. At least some stock trading is value-adding, and secondary markets do provide some social benefits by providing prices that can signal the allocation of capital and liquidity that promotes mvestor mterest in new issues. A tax that significantly diminishes but does not eliminate stock trading might well produce substantial social gains by reducing the incidence of speculative trading while largely preserving the markets' liquidity and signaling functions. Keynes proposed such a tax when lie commented:

It is usually agreed that casinos should, in the public interest, be inaccessible and expensive. And perhaps the same is true of Stock Exchanges .... The introduction of a substantial Government transfer tax on all transactions might prove the most serviceable reform available, with a view to mitigating the predominance of speculation [in stock markets]. ${ }^{303}$

Because a stock transfer tax would necessarily deter a number of value-adding transactions, as well as a larger number of speculative trades, legal rules that mitigate welfare losses due to speculation by either encouraging investors to develop lounogeneous expectations or reducing inarginal costs (where demand for trading is relatively inelastic) are, in theory, superior to rules taxing or prohibiting trading. But as a practical inatter, mvestors will disagree, and demand for trading does seein to be highly elastic. ${ }^{304}$ Thus, as Keynes observed, cruder instruments sucl as a transfer tax may well prove the most "serviceable" reforms available in reducing the welfare losses that fiow from speculation.

301 See supra notes 215-17 and accompanying text.

302 Supra Parts II.B.1-II.B.2.

303 Keynes, supra note 10 , at 159-60.

304 See supra notes 59-64 and accompanying text (describing evidence of highly elastic demand). 
D. Some Thoughts on HE Theory's Applicability to Other Speculative Markets, Especially Derivatives Markets

Imperfect information can be a cause of market failure. This basic primciple of econoumc theory has important normative implications for stock markets, where imperfect information tempts investors who disagree over stock values to squander resources playing the negative-sum game of stock trading and distorts their views of the value of corporate equities. The evidence indicates that in modern equities inarkets, welfare losses from speculative trading are substantial and far outstrip any likely hquidity or efficiency benefits of such trading.

The observation that heterogeneous expectations may lead to market failure in stock markets naturally raises the question of why the HE inodel should apply only to trading in corporate equities. This Article has focused on equities trading primarily because stock trading is so often presumed beneficial, the stock markets are large and socially important, extensive empirical evidence is available on equities trading, and modeling equities trading is relatively simple. But stocks are not the only securities traded by investors, and securities markets are not the only speculative markets. There are other areas of econoumc life where the HE model may well be relevant.

The market for litigation, and especially for trials, inay reflect a form of inarket failure due to imperfect information similar to that which inspires speculative stock trading. ${ }^{305}$ For at least a decade the legal hterature has recognized tliat trials are negative-sum games where tlie plaintiff's gain necessarily reflects the defendant's loss, and both parties lose wealtl to attorney fees and other litigation expenses. ${ }^{306}$ Soine scholars have explained this market failure as a consequence of imperfect information and heterogeneous expectations. ${ }^{307}$ Thus, when both parties agree on tlie likely out-

305 See Samuel R. Gross \& Kent D. Syverud, Getting To No: A Study of Settlement Negotiations and the Selection of Cases for Trial, 90 Mich. L. Rev. 319, 320 (1991) ("A trial is a failure.").

306 Id. at 320-22 (reviewing hterature).

307 See Robert Cooter, Stephen Marks \& Robert Mnookin, Bargaining In The Shadow of the Law: A Testable Model of Strategic Behavior, 11 J. Legal Stud. 225, 225 \& n.1 (1982) (citing authorities); Gross \& Syverud, supra note 305, at 321 \& n.5 (citing authorities).

An alternative theory is that settlement negotiations fail when parties behave strategically by "holding out." Id. at 321 \& n.6 (citing authorities). 
come of trial, they usually settle. It is only when litigants disagree-specifically, when the plaintiff is more optimistic in her assessment of her chances at trial than the defendant is-that parties insist on the social waste of a trial. ${ }^{308}$

As Keynes' casino comparison implies, another activity that may reflect market failure due to heterogeneous expectations is the market for certain kinds of gambling games. The HE model predicts that gambling games that involve an element of skill, such as handicapping thoroughbreds or playing blackjack, will attract an optimistic, self-selected subset of gamblers, each of whom beheves her knowledge of horses or skill at playing the odds is better than the average gambler's. ${ }^{309}$ Transaction costs in the form of the house percentage ensure, however, that gamblers leave racetracks and casinos poorer than they arrived. Of course, even if gaunblers on average lose wealth, they may find that the excitement and glitter of Churchill Downs or Atlantic City provide recreational value that more than makes up for their losses. Economists frequently hypothesize that gamblers do extract utility from their negativesum games, and most individuals do seem to find gambling more enjoyable than either poring over stock and mutual fund reports ${ }^{310}$ or being a party to litigation. ${ }^{311}$ Nevertheless, the HE model offers an alternative - and less bemign-explanation for the popularity of

308 The fact that attorneys are often paid on an hourly basis for trial work suggests that they may face conficts of interest similar to those faced by brokers and sometimes inay play a similar role in fostering hitigation by encouraging hitigant disagreement. Cf. supra Part I.D.1 and accompanying text.

309 That observation raises the interesting question of why rational imdividuals would play negative-sum gambling games that do not involve an element of skill or forecasting, such as lotteries. See generally Edward J. McCaffery, Why People Play Lotteries and Why It Matters, 1994 Wis. L. Rev. 71 (arguing that the decision to play lotteries is a rational consumer choice inconsistent with conventional economic theories regarding risk aversion).

310 Although the stereotype of the Florida retiree who enjoys "playing the market" raises the possibility that some investors trade for entertaminent, closer analysis suggests that recreation is likely to play only a minimal role in equities trading. See supra note 33 (discussing and critiquing recreational theory of mvesting).

311 See Learned Hand, The Deficiencies of Trials To Reach The Heart of the Matter, Address Before the Association of the Bar of the City of New York (Nov. 17, 1921), in Association of the Bar of the City of N.Y., Lectures on Legal Topics: 1921-1922, at 89, 105 (1926) ("After now some dozen years of experience I must say that as a hitigant I should dread a lawsuit beyond almost anything else short of sickness and death."). 
casinos that resonates with the moral condemnation many laymen heap upon gambling. ${ }^{312}$

A detailed discussion of the markets for hitigation and gambling hes beyond the scope of this analysis. More closely related, however, is the possibility that heterogeneous expectations underhe a third, and inuch larger, market: the vast and growing market for financial derivatives. ${ }^{313}$ Derivatives are instruments whose value depends on some underlying asset, rate, or imdex. For example, one common form of derivative is the "stock index future." Index futures are contracts for the future delivery of a group of stocks that comprise a particular stock index, such as the Standard \& Poor's $500 . .^{314}$ Because index futures generally sell at prices that closely follow the current prices of the stocks that make up the underlying index, a bullish trader might buy index futures, expecting stock prices to rise so that the stocks to be dehvered will be worth considerably more than the futures price on the delivery date. Conversely, a bear will sell index futures, expecting she will soon be able to purchase the stocks she has agreed to dehiver at a lower price. Other common forms of derivatives include options and futures contracts based on interest rates, commodities prices, and currency exchange rates. ${ }^{315}$

Because derivatives trading is largely unregulated and unreported, reliable information on exactly who is trading what, with whom, and why, is difficult to obtam. ${ }^{316}$ The General Accounting

312 See Hazen, supra note 6, at 994.

313 See Hu, supra note 8, at 1459 ("The OTC derivatives market has enjoyed enormous growth"); Lenzner \& Heuslein, supra note 8, at 63, 66 (noting that althongh a few decades ago derivatives markets were an "obscure backwater" of the securities markets, now financial world is "waist-deep in derivatives" to a degree that "few laymen understand"). See generally U.S. General Accounting Office, Fmancial Derivatives: Actions Needed To Protect the Financial System (1994) (discussing derivatives); Hazen, supra note 6 (analyzing the effect of derivatives on market efficiency); Hu, supra note 8 (discussing banker and regulator informational failure with respect to derivatives).

314 See supra notes 153-54 and accompanying text (discussing stock indexes).

315 See U.S. General Accounting Office, supra note 313, at 26-29 (describing basic types of derivatives).

316 See $\mathrm{Hu}$, supra note 8, at 1463 (noting that regulators know little about derivatives market); U.S. General Accounting Office, supra note 313, at 7, 34 (noting that there are "no comprehensive industry or federal regulatory requirements" for derivatives and that "complete information about global derivatives volume" is unavailable). 
Office has estimated that in 1992 the notional amount ${ }^{317}$ of interest rate, exchange rate, and equity and commodity price derivatives outstanding globally exceeded $\$ 17$ trillion, representing an increase of $145 \%$ since $1989 .{ }^{318}$ The sudden appearance and rapid growth of such an enormous and poorly understood inarket has aroused apprehension among some inembers of the financial services industry and government policymakers. ${ }^{319}$ Nevertlieless, the economic presumption that voluntary transactions are mutually beneficial has armored the practice of derivatives trading against cliallenges, just as it has protected the derivatives markets' progeintor, the stock market. Scholars and regulators alike justify derivatives inarkets as beneficial to market participants and society as a whole. ${ }^{320}$

And how, exactly, do these arcane imstruments further social welfare? Derivatives generally are defended as allowing market participants-including banks, insurance firms, securities firms, institutional investment funds, and corporations - to reduce risk by "lredging" agaimst future changes in the prices of equities, coininodities, and interest and exchange rates. ${ }^{321}$ Thus, for example, an Oklahoma retail store whose clientele consisted largely of oil firm einployees miglit want to protect itself from a decline in business revenues by purcliasing an oil-futures derivative that rises im value if oil prices fall, whereas a commercial airline might sell such a derivative to offset the risk of rising fuel prices. ${ }^{322}$

If derivatives are used primarily for hedging (as in the example above), derivatives trades tend to be mutually beneficial. In sucli a value-adding inarket, a free-market approacl that promotes trading and minimizes regulatory imterference may well be wise. ${ }^{323}$

317 See Hu, supra note 8, at 1459 n.6, 1467 n.44 (illustrating notional amount in interest rate swaps context).

318 U.S. General Accounting Office, supra note 313, at 35 tbl. 2.1.

319 Id. at 6.

320 See supra note 8 and accompanying text.

321 See U.S. General Accounting Office, supra note 313, at 6 ("Derivatives serve an inportant function in the global financial marketplace, providing end-users with opportunities to better manage financial risks ...."); see also Hazen, supra note 6, at 100709 (noting that futures literature defends futures trading as allowing risk allocation and inproving accuracy of prices).

322 This is a sliglitly inodified version of an example offered by Professor Henry T.C. Hu, supra note 8 , at 1466 .

323 Even in sucl a case, lowever, the size and riskiness of the derivatives markets have led soine regulators to believe that regulation is necessary to reduce systemic risk, i.e., the 
Academics and regulators have observed, however, that derivatives can be used not only to hedge against risk, but also to speculate on the future. ${ }^{324}$ Thus a corporation might buy an oil derivative that rises in value as oil prices fall not as a hedge, but as a (hopefully profitable) bet on its forecast that oil prices will soon decline. ${ }^{325}$

As in the case of stock trading, only empirical inquiry can answer the question of whether inost derivatives trades reflect hedging or speculation. Nevertheless, recent events suggest that speculation may play a large, if not a dominant, role im derivatives trading. In April 1994, for example, Procter \& Gamble was forced to announce that it had suffered a $\$ 102$ million loss on derivatives contracts entered into by Procter \& Gamble executives who were "bullish" on interest rates. ${ }^{326}$ (The company later announced that the transactions were mistakes "imconsistent" with the coinpany's pohicy of avoidmg financial speculation.) ${ }^{327}$ Procter \& Gamble may have been lucky; shortly afterwards, Pame Webber Group announced that it would spend $\$ 180$ million shoring up a mutual fund that had tried to bolster its profits with derivatives trades, ${ }^{328}$ and a few inonths before, the German congloinerate Metallgesell-

possibility that the sudden failure or withdrawal of a large participant in the system could trigger a series of similar failures. U.S. General Accounting Office, supra note 313, at 7-8.

324 See Hazen, supra note 6, at 1017-18 (providing example of speculative use of derivative); U.S. General Accounting Office, supra note 313, at 25 (noting that speculators use derivatives to try to profit from anticipating price changes).

325 The derivatives literature also postulates that derivative instrumeuts can be used for "arbitrage," riskless trades that extract profits by exploiting small differences between the market price of a derivative and the market price of an underlying asset, or small differences between excliange rates or interest rates in different capital markets. Hu, supra note 8, at 1466 (discussing use of derivatives for arbitrage); U.S. Geueral Accounting Office, supra note 313 , at 25 (noting use of derivatives to obtain more favorable financing througl interest rate arbitrage). From an economic perspective, arbitrage trades, like speculative trades, generally are zero-sum transactions that transfer wealth but do not add to social welfare.

326 See Susan Antilla, P. \& G. Bet on Rates Turns Sour, N.Y. Times, Apr. 13, 1994, at D1, D15.

327 Kelley Holland \& Zachary Schiller, Did Procter \& Gamble Play with Fire?, Bus. Wk., Apr. 25, 1994, at 38, 38 (quoting Procter \& Gamble CEO Edwin L. Artzt); see also Saul Hansell, A Bad Bet for P. \& G., N.Y. Times, Apr. 14, 1994, at D6, (noting that executive in charge of transactions was put on "special assignment").

328 Leslie Eaton, Yet Another Round in Greed vs. Prudence, N.Y. Times, July 25, 1994, at $\mathrm{D} 1$. 
schaft AG announced potential losses of nearly $\$ 1$ billion from energy derivatives. ${ }^{329}$

Such stories hardly sound like the stories of financial technicians negotiating mutually beneficial deals to adjust for market risk. Rather, they resemble the woeful tales of bettors at the racetrack who backed the wrong horse and must now tear up their tickets and go lome. Heterogeneous expectations theory supports the idea that the derivatives markets provide fertile ground for speculation. The HE model predicts that, given a particular level of dispersion in investor expectations for future stock returns, speculative trading becomes more likely as transaction costs decrease. The low transaction costs associated with derivatives trading allow market participants who want to gamble on changes in stock prices (or interest rates, or exchange rates) to take a larger position in those markets at far less expense than by trading in the underlying market. ${ }^{330}$ Thus, HE theory predicts that derivatives markets are likely to attract a very high portion of those optimists willing to bet they are better than the next trader at forecasting the futures of industries, interest rates and national economies.

If the derivatives market is primarily a speculative market driven by disagreement over the future, what consequences follow? Most obviously, derivatives trading may pose a significant risk of adding to the welfare losses that society already suffers from equities trading because imdividuals and imstitutions may be enticed to expend resources researching, managing and tradimg derivatives, just as they now spend resources researching, managing and trading stock portfohos. To some extent, of course, one loss may simply substitute for the other. In other words, some of the resources expended on derivatives speculation might have been lost in any case to stock speculation. Yet developing a derivatives market seems likely to imcrease net social losses from financial speculation for at least two reasons.

First, as noted above, if the demand for speculative trading is relatively elastic, the lower transaction costs associated with derivatives trading may tempt market participants to incur larger net

329 Jeffrey Taylor \& Allanna Sullivan, German Firm Finds Hedges Can Be Thorny, Wall St. J., Jan. 10, 1994, at C1, C14 (describing losses as result of a "glitcll" in the coinpany's attempt to lhedge risk).

330 See $\mathrm{Hu}$, supra note 8, at 1466. 
costs by greatly increasing their interest in, and the incidence of, speculative trading. Second, and perhaps inore significantly, derivatives markets inay increase net social losses froin speculation because they offer market participants a novel and untried way to bet on their heterogeneous expectations for the future. As discussed in Part I, mcreasing the number of markets, instruments, and manners in which investors are able to speculate can increase their net losses from speculative trading. Allowing mdividuals to invest through intermediaries such as mutual funds, for example, can increase speculative losses by allowing individuals to make new and different mistakes. ${ }^{331}$ The individual investor who has learned from bitter experience that she is no good at picking winning stocks inay be tempted to see if she is better at picking winning inutual fund inanagers. Similarly, Procter \& Gamble executives who would not think of hazarding their firm's fortunes on their own stock-picking talents might nevertheless speculate in derivatives, believing they have superior ability to forecast changes in interest rates. ${ }^{332}$

The observation that harsh lessons learned in one market do not necessarily carry over to another suggests that financial "innovations" that lead to new and better financial products may actually lead primarily to new and better ways for individuals and institutions to make expensive speculative mistakes. As Nobel laureate James Tobin has warned: "Every financial market absorbs private resources to operate, and government resources to police. The country cannot afford all the markets that enthusiasts may dream up." ${ }^{333}$ Champions of derivatives trading soinetimes describe those who are more cautious as resistant to financial progress. ${ }^{334}$ The HE model of trading, however, provides a theoretical foundation

331 See supra notes $91-92$ and accompanying text.

332 By introducing a new market in which traders can test their heterogenous expectations, derivatives have contributed to the significant increase in the size of the U.S. financial industry over the past decade. See Lenzner \& Heuslem, supra note 8, at 64 (estimating that "what we loosely call Wall Street" has gone from absorbing about one-half of one percent of Gross Domestic Product a decade ago, to one percent today largely because of derivatives).

333 Tobin, supra note 10 , at 10 .

334 See, e.g., Lenzner \& Heuslem, supra note 8, at 72 (comparing growth of derivatives to invention of internal combustion engine); see also Hu, supra note 8, at 1513 (noting that halting derivatives trading would be "Procrustean, unnecessary, and destructive of social wealth"). 
for those who, like Tobin, fear that the fast-growing market in derivatives may serve Wall Street to the detriment of Main Street and the greater society. ${ }^{335}$ Resources lost chasing the illusion of speculative profits are resources that could have been invested in programs that mcrease social wealth by developing new technologies, improving products, or cutting production costs. Thus, in the regulation of speculative inarkets, laissez-faire can lead to loss.

\section{Conclusion}

We hive in a world of ignorance and uncertainty. Although im some cases economists can reasonably assume away the market effects of imperfect information, in other circumstances economic theories preinised on perfect information can be dangerously misleading. As the economist George Stigler observed:

Ignorance is like subzero weather: by a sufficient expenditure its effects upon people can be kept within tolerable or even comfortable bounds, but it would be wholly uneconomic entirely to eliminate all its effects. And, just as an analysis of man's shelter and apparel would be somewhat incoinplete if cold weather is ignored, so also our understanding of economic life will be imcomplete if we do not systematically take account of the cold winds of ignorance. ${ }^{336}$

In the case of stock markets, any analysis that ignores ignorance risks being incomplete indeed. Ignorance about the future breeds disagreement, and disagreement in turn breeds investor tradimg im the hope of quick gams. Although the conventional economic models most often employed by conteinporary financial theorists to describe stock markets are exphcitly premised on the assumption that investors hold identical expectations for the future risks and returns of stocks, in reahity even experts differ widely in predicting the fates of firms, industries, and the economy as a whole. Such disagreement tempts imdividual investors and institutional managers alike to abandon conservative buy-and-hold strategies and try their hand at trading in the statistically futile hope of beating the market. Although such trading is self-defeating-research

335 See Stiglitz, supra note 9, at 103 (suggesting that financial innovation may produce more welfare losses than gains such that "[b]arring these innovations . . . could actually make everyone better off").

336 Stigler, supra note 35, at 224. 
and trading costs ensure that investors who cliurn their portfolios on average underperform the market-it is not irrational. Indeed, econoumic theory explains that in a world of imperfect information where investors necessarily make differing judgments of both stock values and their own relative trading abilities, the wasteful expenditure of valuable resources on the negative-sum game of stock trading is not only rational but inevitable.

Recognizing the importance of disagreement in fosterimg stock trading allows construction of a model of stock trading and stock markets that offers great promise in describing and predicting the behavior of both equities markets and those who participate in them. This HE trading model offers insights into why investors trade, who is inost likely to trade and for how long, the role of selfselection and successive generations in creating and sustaining markets, the role of financial intermediaries, how prices are set, and the imcertam relationship between market prices and best estimates of stock values. In doing so, the $\mathrm{HE}$ model paints a portrait of equities markets that departs significantly from models currently in vogue, yet accords well with both the empirical evidence and the perceptions of those who actually participate in stock markets.

In addition to its enormous positive utility, the HE model also carries important normative miphcations for the appropriate regulation of stock markets. Experts often dismiss the layman's disapproval of speculation. HE theory suggests, lowever, that the popular condemnation of wealth gamed through speculation has a sound basis in economic theory. The HE model implies that speculative stock trading is, $\mathrm{m}$ an economic sense, a wasteful mistake. Although investors who trade on their heterogeneous expectations believe they will increase their wealth by domg so, their belief is on average erroneous, and their trading on average leaves them worse off. A conservative estimate of the expenses associated with stock speculation suggests that investors may be spending $\$ 100$ billion annually-fully one-fifth of their returns from imvesting-on researching and trading corporate equities. If most stock transactions are inspired by imvestor disagreement - and considerable evidence suggests most are-then, at least in the case of stock markets, tradimg based on heterogeneous expectations leads to substantial net welfare losses for both traders and society as a whole. Investors' optimnistically mistaken perceptions that they can 
increase their returns from stock ownership by trading also may lead to welfare losses by creating false substitution and false valuation effects that distort demand for corporate equities and may result in the misallocation of imvestment capital and other resources.

The HE model of trading thus undermines the views of commentators and regulators who perceive stock inarkets as finely tuned, highly efficient allocative instruments. Rather, the HE model predicts that speculative stock markets reflect a costly form of market failure that erodes social wealth while offering few benefits in return. This possibihty has significant consequences for current law, much of which is devoted to promoting stock trading and encouraging the development of new instruments and markets. HE theory suggests that federal securities policy instead should seek to minimize the incidence and costs of speculative trading.

Differences of opinion make a liorse race. ${ }^{337}$ They also inake a thriving stock market because differences of opinion allow both buyer and seller to believe that they can increase their wealth by playing the negative-sum game of stock trading. By recognizing that reality, the HE trading model offers valuable gnidance to the academics who study securities markets, the lawmakers who regulate them, and the investors who trade in them.

337 In Mark Twain's Pudd'nhead Wilson, the eponymous hero observes, "It were not best that we should all think alike; it is difference of opinion that makes horse-races." Samuel L. Clenions, Pudd'nhead Wilson and Those Extraordinary Twins 92 (Sidney E. Berger ed., W.W. Norton \& Co. 1980) (1894). 